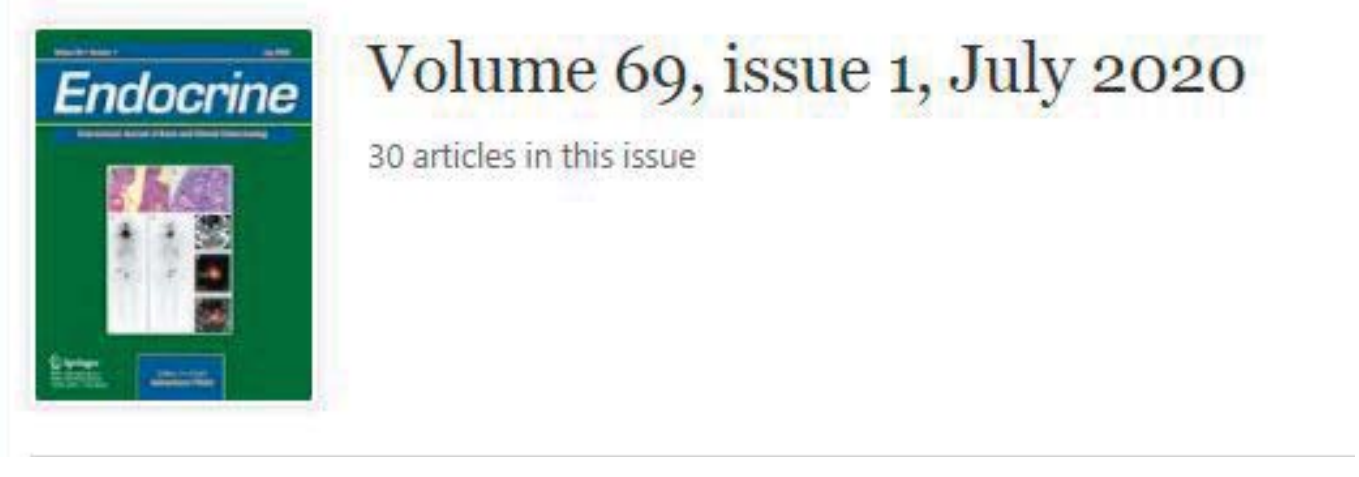




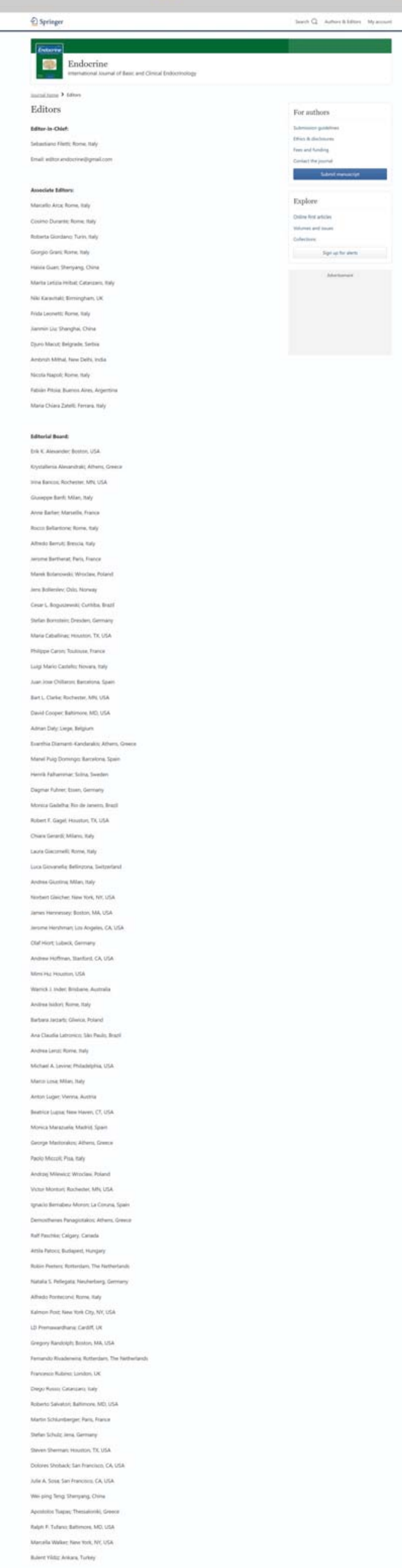

9) sprien

$\equiv \equiv$ 


\section{E Emarie}

高

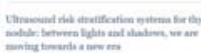

드.

sin-

$=$

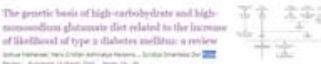

$\pm$

$=$

$=$

$=$

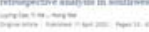

垈

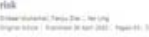

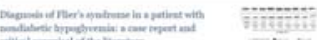

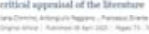

stistom

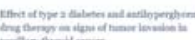

sente

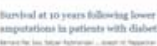

tons

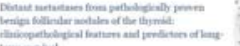

$=$

$=$

$=-1$

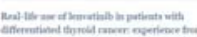

$x=-\cdots$

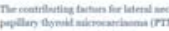

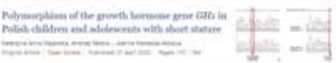

$=$

5

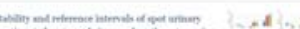

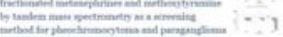

단ㄷㄴ

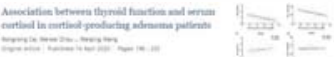

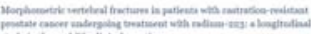

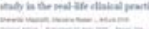

$\mathrm{H}$

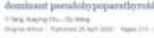

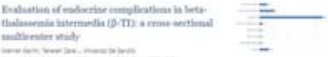

$=$

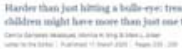

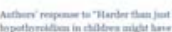

$=-2=-=$

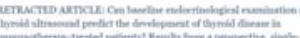

$+2$
[

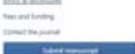

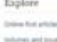

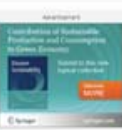




\section{Endocrine}

\section{The Genetic Basis of High-Carbohydrate and High-MSG Diet Related to the Increase of Likelihood of Type 2 Diabetes Mellitus: A Review --Manuscript Draft--}

\begin{tabular}{|c|c|c|}
\hline Manuscript Number: & \multicolumn{2}{|l|}{ ENDO-D-19-00913R1 } \\
\hline Full Title: & \multicolumn{2}{|c|}{$\begin{array}{l}\text { The Genetic Basis of High-Carbohydrate and High-MSG Diet Related to the Increase } \\
\text { of Likelihood of Type } 2 \text { Diabetes Mellitus: A Review }\end{array}$} \\
\hline Article Type: & \multicolumn{2}{|l|}{ Review } \\
\hline Corresponding Author: & \multicolumn{2}{|l|}{$\begin{array}{l}\text { Sulistyo Emantoko Dwi Putra } \\
\text { Universitas Surabaya } \\
\text { Surabaya, East Java INDONESIA }\end{array}$} \\
\hline \multicolumn{3}{|l|}{$\begin{array}{l}\text { Corresponding Author Secondary } \\
\text { Information: }\end{array}$} \\
\hline Corresponding Author's Institution: & \multicolumn{2}{|l|}{ Universitas Surabaya } \\
\hline \multicolumn{3}{|l|}{$\begin{array}{l}\text { Corresponding Author's Secondary } \\
\text { Institution: }\end{array}$} \\
\hline First Author: & \multicolumn{2}{|l|}{ Joshua Nathanael } \\
\hline \multicolumn{3}{|l|}{ First Author Secondary Information: } \\
\hline \multirow[t]{6}{*}{ Order of Authors: } & \multicolumn{2}{|l|}{ Joshua Nathanael } \\
\hline & \multicolumn{2}{|l|}{ Hans Cristian Adhinatya Harsono } \\
\hline & \multicolumn{2}{|l|}{ Aubrey Druce Wibawa } \\
\hline & \multicolumn{2}{|l|}{ Putu Suardana } \\
\hline & \multicolumn{2}{|l|}{ yoanes maria vianney } \\
\hline & \multicolumn{2}{|l|}{ Sulistyo Emantoko Dwi Putra } \\
\hline \multicolumn{3}{|c|}{ Order of Authors Secondary Information: } \\
\hline Funding Information: & $\begin{array}{l}\text { Kementerian Riset Teknologi Dan } \\
\text { Pendidikan Tinggi Republik Indonesia } \\
\text { (021/SP-Lit/LPPM- } \\
\text { 01/DRPM/Multi/FTB/III/2019) }\end{array}$ & Dr.rer.nat Sulistyo Emantoko Dwi Putra \\
\hline Abstract: & \multicolumn{2}{|c|}{$\begin{array}{l}\text { Diabetes is one of the most common metabolic diseases. Aside from the genetic factor, } \\
\text { previous studies stated that other factors such as environment, lifestyle, and paternal- } \\
\text { maternal condition play critical roles in diabetes through DNA methylation in specific } \\
\text { areas of the genome. One of diabetic cases is caused by insulin resistance and } \\
\text { changing the homeostasis of blood glucose control so glucose concentration stood } \\
\text { beyond normal rate (hyperglycemia). High fat diet has been frequently studied and } \\
\text { linked to triggering diabetes. However, most Asians consume rice (or food with high } \\
\text { carbohydrate) and food with monosodium glutamate (MSG). This habit could lead to } \\
\text { pathophysiology of Type } 2 \text { Diabetes Mellitus (T2D). Previous studies showed that high- } \\
\text { carbohydrate or high-MSG diet could change gene expression or modify protein } \\
\text { activity in body metabolism. This imbalanced metabolism can lead to pleiotropic effects } \\
\text { of diabetes mellitus. In this study, the authors have attempted to relate various } \\
\text { changes in genes expression or protein activity to the high-carbohydrate and high- } \\
\text { MSG induced diabetes. The authors have also tried to relate several genes that } \\
\text { contribute to pathophysiology of T2D and proposed several ideas of genes as markers } \\
\text { and target for curing people with T2D. These are done by investigating altered } \\
\text { activities of various genes that cause or are caused by diabetes These genes are } \\
\text { selected based on their roles in pathophysiology of T2D. }\end{array}$} \\
\hline Response to Reviewers: & \multicolumn{2}{|c|}{$\begin{array}{l}\text { When revising your work, please submit a list of changes or a rebuttal against each } \\
\text { point which is being raised when you submit the revised manuscript. } \\
\text { Your revision is due by } 25 \text { Feb } 2020 \text {. }\end{array}$} \\
\hline
\end{tabular}


You will see a menu item called 'Submissions Needing Revision'. You will find your submission record there.

Please make sure to submit your editable source files (i.e. Word, tex).

Yours sincerely,

Sebastiano Filetti

Editor-in-Chief

Endocrine

\section{COMMENTS FOR THE AUTHOR:}

Reviewer \#1: 1- MSG (monosodium glutamate) as an abbreviation should be spelled out in the title as well as the abstract and should be added into the abbreviation list. Moreover, MSG should be spelled out when it is first mentioned then only MSG and not monosodium glutamate should be used later. This should be done for all the used abbreviations.

Reply: MSG and T2D in the title, and abstract have been prolonged for the first time However, for the gene name, we still use the abbreviations.

2- The manuscript should be revised for linguistic and grammatical mistakes as well as typographical errors e.g. the authors (in the abstract), dephosphorilation of FoxO1 (in Figure 1) and in page 5 line 119 "Scd1 deficient alone ..." should be "Scd1 deficiency alone ...".

Reply: We are grateful for the input. We change the figure 1 also ask Mrs Helen to recheck and do some proofread on the manuscript.

3- The authors stated that high carbohydrate diet plus high intake of MSG contribute to the emergence of type 2 diabetes. The authors should differentiate between correlation and causation. The authors should show which studies revealed only that the prevalence of type 2 diabetes is correlated with high carbohydrate diet and high intake of MSG and which studies investigated the possibility that high carbohydrate diet and high intake of MSG could lead to type 2 diabetes.

Reply: we deleted the sentence "both factors combine to increase risk of T2D" in the introduction. We noticed that we have to tone down this sentence. Therefore, we just put this as hypothesis that might be interesting to be investigated in animal studies in the last paragraph in the genetic aspects section (before entering human population study).

For genetic aspects, such as in Table 1, we already wrote that for genes which affects T2D development, it is highly probable that disruption of those genes by imbalance diet could lead to the onset of hyperglycemia. As for changed by T2D, then the hyperglycemic period happen first that lead to the change to gene expression. However, indeed many genes are still on the side of N.D., which is the there is missing link on the time period of the activation of the phenotypes. Meanwhile, it can be also caused by a feedback loop from the activation / suppression of the genes itself that create vicious cycle. Also to give balance to the experimental data, we then added a new section about human-population study. This will describe more about the correlation between lifestyle and diet to the metabolic disorders. We also added several sentences in the MSG section and in the epidemiology studies that highlighted the main difference in the treatment for MSG case, in which in various animal, genetic, and experimental studies, the model was created by MSG injection, and not by feeding.

4- Are there any studies showing non-significant correlation between the prevalence of type 2 diabetes is and high carbohydrate diet as well as high intake of MSG? You should show all relevant studies!!

Reply: We added some results from epigenetic studies related to the onset of T2D due to high-carbohydrate and high-MSG diet. We also added a new section related to a more comprehensive epidemiological data so that the experimental data can be 
compared with population-based study and gave a bigger picture of the status quo on both high-carbo and high-MSG. Indeed, despites various factors plays in the epidemiological study, major results for high-carbohydrate is that high-carbohydrate diet is positively correlated with diabetes and could also gave rise to diabetes for a healthy patient. But for high-MSG diet, many results are in conflict to each other. We also tried to give some explanation to this in the new section and also in the first paragraph of the impact of MSG by describing the fate of MSG in the gut and why MSG can be considered GRAS as food additive.

5- It would be great if the authors can explain the strategy they used to pick up the genes to be discussed in this review.

Reply: New sentences are added in the last paragraph of the introduction to explain basic ideas on how we screen some genes and gather the articles to assign the review.

6- I suggest adding a small paragraph about the fate (absorption and metabolism) of MSG after its ingestion.

Reply: A new paragraph is added in the impact of MSG section as its first paragraph (line 173-179). There, we describe how MSG can be considered GRAS as food additive We also added a new paragraph after the section to differentiate that various genetic and experimental data employed either MSG injection (subcutan or peritoneal) or by cell culture not by feeding.

7- The authors should also mention epigenetic mechanism leading to insulin resistance by referring to: J Hypertens. 2019;37(11):2123-2134.

doi:10.1097/HJH.0000000000002156. Is something known about epigenetic mechanisms of High-Carbohydrate and High-MSG Diet induced insulin resistance? Reply: Epigenetic experimental data have been added in the introduction, such as famine, related to low birth weight, imbalance diet, fetal programming by impaired maternal.

8- In Figure 3, what is the relation between the factors in the upper part of the figure and the term "MSG induced".

Reply: it has been corrected to

9- The authors should spell out MSG in the title. In general, use rather full names then abbreviations.

Reply : It is corrected. 
1

1 The Genetic Basis of High-Carbohydrate and High-Monosodium Glutamate Diet Related to

2 the Increase of Likelihood of Type 2 Diabetes Mellitus: A Review

3 Joshua Nathanael, Hans Cristian Adhinatya Harsono, Aubrey Druce Wibawa, Putu 4 Suardana, Yoanes Maria Vianney, Sulistyo Emantoko Dwi Putra*.

5

6 Department of Biology, Faculty of Biotechnology, University of Surabaya, Raya Kalirungkut, 7 Surabaya 60292, East Java, Indonesia

8 *Corresponding author: emantoko@staff.ubaya.ac.id 9

10 ORCID ID: Yoanes Maria Vianney = 0000-0002-4576-9935

11 ORCID ID: SulistyoEmantokoDwi Putra = 0000-0001-8469-9688 


\section{Abstract}

Diabetes is one of the most common metabolic diseases. Aside from the genetic factor, previous studies stated that other factors such as environment, lifestyle, and paternal-maternal condition play critical roles in diabetes through DNA methylation in specific areas of the genome. One of diabetic cases is caused by insulin resistance and changing the homeostasis of blood glucose control so glucose concentration stood beyond normal rate (hyperglycemia). High fat diet has been frequently studied and linked to triggering diabetes. However, most Asians consume rice (or food with high carbohydrate) and food with monosodium glutamate (MSG). This habit could lead to pathophysiology of Type 2 Diabetes Mellitus (T2D). Previous studies showed that highcarbohydrate or high-MSG diet could change gene expression or modify protein activity in body metabolism. This imbalanced metabolism can lead to pleiotropic effects of diabetes mellitus. In this study, the authors have attempted to relate various changes in genes expression or protein activity to the high-carbohydrate and high-MSG induced diabetes. The authors have also tried to relate several genes that contribute to pathophysiology of T2D and proposed several ideas of genes as markers and target for curing people with T2D. These are done by investigating altered activities of various genes that cause or are caused by diabetes These genes are selected based on their roles in pathophysiology of T2D.

Keywords: gene expression, high carbohydrate, insulin resistance, metabolism, monosodium glutamate, obesity, regulatory protein, type 2 diabetes mellitus.

\section{Abbreviations}

GLUT4 Glucose transporter 4

PDX1 Pancreatic and duodenal homeobox 1

NKX6.1 NK6 homeobox 1

MAFA MAF bZIPtranscritpion factor A

FOXO1 Forkhead box protein O1

GRP-78 Binding immunoglobulin protein

PERK Protein kinase R (PKR)-like endoplasmic reticulum kinase

IRE1 $\alpha \quad$ Inositol-requiring enzyme $1 \alpha$

XBP1 X-box binding protein 1

CHOP $\quad$ C/EBP homologous protein 
INSIG1 Insulin induced gene 1

SREBP-1c Sterol regulatory element binding protein 1c

SIRT1 NAD-dependent deacetylase sirtuin-1

SCD1 Stearoyl-CoA desaturase-1

PPAR Peroxisome proliferator-activated receptor

ATF4 Activating transcription factor 4

CREB-2 CAMP-response element binding protein 2

MEG3 Maternally expressed 3

SLC2A4 Solute carrier family 2 member 4

H3K9me3 Trimethylation of lysine 9 on histone $\mathrm{H} 3$ protein

PCK1 Phosphoenolpyruvate carboxykinase 1 (soluble)

ACO Acyl-CoA oxidase

CPT1 Carnitine palmitoyltransferase 1

BIFEZ Bifunctionalenzyme

ANGPTL4 Angiopoietin-like 4

PDK4 Pyruvate dehydrogenase lipoamide kinase isozyme 4

TIF2 Transcriptional mediators/intermediary factor 2

UCP3 Mitochondrial uncoupling protein 3

PGC-1 $\alpha$ Peroxisome proliferator-activated receptor gamma coactivator 1-alpha

SRC 1 Steroid Receptor Co-activator 1

aP2 Adipocyte Protein 2

SHP Small Heterodimer Partner

MSG

Monosodium Glutamate

\section{Introduction}

Diabetic prevalences are continuously increasing and they were predicted to reach 693 million in 2045[1]. Various factors contributed to the emergence of diabetes ranging from parental genetics [2], maternal epigenetic inheritance due to nutritional imbalances consumption during pregnancy [3], lifestyle, and diet [4, 5]. Physiologically, diabetes could be due to insulin resistance [6], insulin secretory dysfunction [7], or death of pancreas $\beta$-cell [8]. The pathogenesis of Type 2 diabetes mellitus (T2D) related to obesity has been well reviewed [6]. Epidemic and epigenetics 
that convey relationship between genetics and environment are closely related to T2D cases $[9,10]$. The fact that famines impact on the family health, pregnancy planning, lifestyle, and diet in early stages of pregnancy contributed to future risks of various metabolic disorders, such as obesity and diabetes. This fact has been well-reviewed in the literature [9]. Various environmental factors previously mentioned lead to various epigenetic modifications and cause early insulin resistance associated with the fetal low birth weight [10].

Certain patterns of diets increase the chances of T2D due to alteration in the gene expression. High-fat diet is the most commonly studied and frequently used to induce diabetes [11, 12]. High-fat diets internalize and reduce the expression of pancreatic glucose transporter gene (GLUT2) and glucokinase caused by the hyperglycemia and create a vicious loop of impaired insulin secretion $[13,14]$. This diet also reduces the expression of GLUT4 protein and causes insulin resistance in skeletal muscles. High-fat diets also inactivated insulin receptor substrate (IRS-1) in liver and caused inflammation in mice models [15]. Methylation studies on PDK4 also revealed that high-fat-diet-induced methylation on a specific CpG site before the onset of hyperglycemia as one proof of epigenetic regulation plays an important role in metabolic disorder [16].

Primary food with high glycemic index, such as rice, is a staple food for more than half of the world's population in various Asian countries [17]. High carbohydrate diet, such as refined grain is also associated with an increased risk of T2D [18-20]. High sucrose and fructose diets are also contributing factors to T2D since sucrose and fructose cause pancreas and liver toxicity [2123]. Another relevant Asian food additive that can induce T2D is the high intake of MSG [24-28]. Epigenetically, a newborn female in the suckling period who eats a high-carbohydrate diet has been reported to readily develop hyperinsulinemia and to acquire obesity in the adulthood [29]. The second generation of these female rats spontaneously develop the similar phenotype even without any intervention studies indicating maternal fetal programming [29]. MSG-induced obesity by subcutaneous injection of female Wistar rats' parent, has been reported to bring forth male offspring that experienced various metabolic disorders, such as insulin and leptin resistance [30]. These initial facts implied that both high-carbohydrate and high-MSG diets contribute to the emergence of T2D.

To the extent of the authors' literature reviews, diets with high carbohydrate and high MSG have not been so extensively reviewed as those with high fat (especially in the consequences of 
high-carbohydrate and high-MSG intakes on gene expression). This review focuses on exploring the genetic interactions of both diet patterns that leads to T2D. Literature reviews related to T2D and human central metabolism were employed to initially screen some genes or proteins that have been extensively studied. Then, the possibilities of alteration of these genetic expressions using carbohydrate and MSG adjustment were also investigated. Thus, this review can provide insights into the screening processes of genes that can serve as potential biomarkers in T2D prediction. The genes or the proteins can also offer possible breakthoughs in therapies for T2D patients.

\section{Genetic Aspects that Promote T2D: High-Carbohydrate Diet Study}

High-carbohydrate feeding after a period of time of non-carbohydrate diets caused the mice to enter fast hyperglycemic period [13]. The high-carbohydrate diet in mice models dephosphorylate FoxO1 without reducing its expression where the phosphorylation was regulated in Akt pathway. Thus, FoxO1 stayed in the nucleus and significantly reduced the expression of PDX1, NKX6.1, and MAFA genes that are essential for the survival and the maintenance of $\beta$ pancreas cell and insulin production [13, 31, 32]. High-fructose diets were also found to increase both the m-RNA content of FoxO1 and the expression of pancreatic GRP-78, PERK, IRE1 $\alpha, X B P 1$, CHOP gene, hepatic GRP-78, and caspase activity [21]. All these genes belong to the family of endoplasmic reticulum stress markers and relate to cell death. Interestingly, high fructose diets also reduce the expression of INSIG1[21]. This is the protein that regulates SREBP-1C that is important to synthesize fat when the cells are rich in carbohydrate [33]. In contrast, activation and retainment of FoxO1 in the nucleus by deacetylation are essential to protect $\beta$-pancreas cell of diabetic mice within the long term by reducing the dependence on fatty acid oxidation as energy source [34]. This signifies that FoxO1 activation might be one approach of our body to control homeostasis.

Animal models showed that high-carbohydrate diet induced the expression of hepatic acetyl-CoA carboxylase stearoyl-CoA desaturase 1 gene (Scd1), while $S c d 1$ normally is not expressed in liver but expressed constitutively in adipose tissue [35-38]. High-carbohydrate diet was found to increase the expression of various elongase and desaturase enzymes that synthesize unsaturated fatty acid, especially mono-unsaturated fatty acid (MUFA) in liver [39]. Scd1 activation created vicious cycle which created insulin resistance. Down-regulation of Scd1 proved to increase the phosphorylation of AKT and to alleviate the insulin resistance [40-43]. 
Although Scd1 might be an interesting gene to be downregulated, Scd1 deficiency alone was found to be insufficient to protect mice from getting obese [44]. In contrast, the activation of Scd1 gene specifically in skeletal muscle enhanced the activation of PPAR- $\delta$ to oxidize fat and increased the metabolism in skeletal muscles that could protect T2D mice from obesity [45]. This opposing phenotype in skeletal muscles and hepatic cells both arising from the activation of Scd1 expression denoted that each protein behaves differently and possibly targets different proteins in each organ. The Scd1 gene correlation with high-carbohydrate diet has been investigated for more than two decades but with no firm consequences. Care must be taken when making a research to silence this gene or to make an inhibitor for Scd1. Clearly, more data are needed to be able to map the effect of Scd1 on not only various genes but also various organs.

ATF4 (or CREB2) deficiency has been shown to suppress the expression of SCD1 in liver, and ATF4-deficiency mice has lower fat content compared to the normal genotype. In highcarbohydrate diet mice, deletion of ATF4 improved insulin sensitivity and caused hypoglycemia [46, 47]. ATF4 deletion also significantly reduced the expression of hepatic PPAR- $\gamma$ which contributed to lipogenesis resulting in reduction of other genes expression involved in lipogenesis, such as SREBP-1c and acetyl-coA carboxylase. ATF4 deletion also protected high-fructose diet mice from developing hypertriglyceridemia and liver steatosis [48]. This fact was further enhanced by the downregulation of ATF4 in liver by miRNA-214 that could alleviate gluconeogenesis and reduce the expression of FoxO1in high-fat diet mice [49]. MEG3, a non-coding RNA, was found to be a competing endogenous RNA (ceRNA) for miRNA-214 that resulted in increase of ATF4 and FoxO1 expressions that create insulin resistance [50]. These facts might seem that downregulating ATF4 or regulating the miRNA214-MEG3 axis can be a promising way to combat T2D. Nevertheless, referring to the contrasting long-term effect of FoxO1 [34], more data are required to observe long-term effects of ATF4 up- or down-regulation on the diabetic animal models.

Evenly, nutritional factors of high-carbohydrate and high-fat diet induced diabetic mice overlap with each other in the genetic pathways when a different metabolic pathway is used. This condition possibly occurs when food enters the body and several mechanisms of metabolisms interact with each other to form a complex mechanism to maintain homeostasis. Prolonged imbalanced diet or excessive carbohydrate consumption may lead to pathophysiology of T2D. The idea of some gene expression and protein activity alterations when the body encounters highcarbohydrate diet is summarized in the following Figure 1. 


\section{Genetic Aspects that Promote T2D: High-MSG Intervention Study}

Monosodium glutamate has been linked with various metabolic disorders. Metabolism of MSG by dietary intake is well reviewed [51]. Glutamate is a non-essential amino acid that is usually oxidized or acted as precursor for other amino acids in gut. With excess of MSG intakes, the intestine capacity to absorb MSG remain unchanged. In neonatal primate, high dose of MSG administered by gastric tube, induced elevation of glutamate and aspartate content (the result of glutamate metabolism by liver) after one or two hours of treatment without any lesion in neuron [52]. Thus, MSG is considered as GRAS food additive.

Here, the focus of the study is the genetical and experimental effects of MSG intervention study towards expression of genes and metabolism. However, it should be taken into account that various experimental data used MSG injection to develop obesity and hyperglycemic animal models to reveal the genetic architecture between MSG and T2D. MSG is also now a suspected obesogen - a small chemical that could disrupt fat metabolism and appetite [53]. MSG was found to impair glucagon-like peptide (GLP-1) secretion in cell model, a peptide hormone that is important for $\beta$-cell growth and insulin production [54]. In short term (3h), secretion of GLP-1 
was increased, but in chronic term $(72 \mathrm{~h})$, cytotoxicity was observed and there was a reduction in GLP-1 secretion [55].

MSG-induced hyperglycemia caused the same insulin resistance phenomenon induced by streptozotocin. MSG also caused obesity in the non-genetic mice models. However, MSG-induced diabetic mice did not experience an increase in expression of TNF- $\alpha$, a marker that is usually used to indicate obesity and might also cause diabetes [56,57]. No reduction of pancreatic $\beta$-cell in the MSG-induced diabetes was observed compared to that in the streptozotocin-induced diabetes [25].

MSG-induced diabetic mice exerted decreased content of GLUT4 protein (not GLUT1), disrupt glucose utilization, and caused insulin resistance [58]. This is due to methylation of Slc2a4 promoter area that produced GLUT4 by H3K9me3 using gastrocnemius skeletal cell [59]. An increase of Slc2a2 gene expression (encoding GLUT2) and pck1 (encoding key enzyme in gluconeogenesis in the liver) was also induced in MSG-diabetic mice. This increase caused glucose outflow and created hyperglycemia [60].

MSG-induced diabetes also takes a longer time to develop hyperglycemia phenomenon, and the obesity period is usually the first indicator [61, 62, 26, 63]. Subcutaneous injection of rats with MSG reduced the expression of genes related to the fat oxidation, such as PPAR $\alpha, A C O$, CPT1, and BIFEZ $[64,65]$. Conversely, MSG-induced diabetic mice in neonatal period gain an increase of expression in PPAR $\alpha$ and PPAR $\gamma$, and inflammation [66]. Although both mechanisms are intertwined, MSG observably induced the lipogenesis. Chiglitazar, the agonist PPAR $\alpha$ and $\operatorname{PPAR} \gamma$, is reported to inhibit the phosphorylation of PPAR $\gamma$, thus deactivates the protein and increases the expression of ANGPTL4 and PDK4[67-69]. ANGPTL4 is a protein that protects human from getting obese and myocardial infarction due to high-fat diet by inhibiting the lipoprotein lipase activity, reducing free fatty acid levels in serum [70]. PDK4 is an enzyme that turns off the pyruvate dehydrogenase and in turn, activates the $\beta$-oxidation pathway that is often expressed in skeletal muscle cell and can be repressed by insulin. An increase of PDK4 expression is often observed in diabetic patients and increases insulin resistance and dependence on fatty acids oxidation as energy source $[71,72]$. However, in a short-term high-fat diet, the increase of PDK4 expression is important to balance the glucose and fat level. The increase of ANGPTL4 and PDK4 expression is regarded as the feedback mechanism to protect cells from fatty acid-induced oxidative stress $[73,74]$. 
High MSG Diet

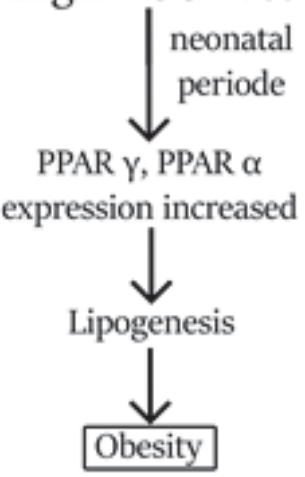

FIGURE 2. Changes of gene expression by MSG-induced diabetes in neonatal period.

The loss of function experiment using skeletal muscle cells and adipocytes on TIF2 revealed PPAR $\gamma$ expression reduction [75]. The deletion of TIF2 reduced the expression of lipoprotein lipase, aP2, and increased lipolysis and the resistance of MSG-diabetic induced mice from getting obese in combination with SRC1 expression for better energy expenditure [75]. Experiment on $\mathrm{TIF}^{-/-}$mouse supported the idea about the role of TIF2 on obesity whereas TIF2 and SRC1 act antagonistically towards UCP3 expression [76]. Silencing TIF2 gene increased the expression of UCP3 and in turn, increased body metabolism and reduced weight gain [77]. Lossof-function of TIF2 also induced the expression of PGC-1 $\alpha$ in skeletal muscle cells, and the expression increased the oxidative metabolism of muscle cell $[76,78]$. SRC3 deletion on mice also increased the PGC-1 $\alpha$ activity by reducing acetylation on skeletal muscle cells [79]. However, expressed PGC-1 $\alpha$ raised different phenotypes from different organs and periods of induction. Pancreatic overexpression of PGC-1 $\alpha$ in neonatal period inhibited the expression of PDX1. The inhibition of PDX1 expression caused dysfunction and mass reduction in pancreatic $\beta$-cell. However, PGC-1 $\alpha$ overexpression in the adult mice did not affect the pancreatic $\beta$-cell [80].

Recently, SIRT1, a histone deacetylase protein, has been proved to increase insulin sensitivity. SIRT1 expression improved glycemic control and insulin sensitivity on liver, muscle, adipose tissue and $\beta$-cell pancreas [81, 82]. It is further supported by mice that are deficient in SIRT1 which develop hyperglycemic and insulin resistance [83]. MSG-induced diabetic mice does not seem to cause any changes in SIRT1 expression level. However, various ligands that acted as SIRT1 activator such as resveratrol, SRT1720, and MHY2233, improved the steatosis condition 
$[60,84,85]$. In contrast, Genetic diabetic $d b / d b$ mice reportedly were in use [86]. Although the activation of SIRT1 did stimulate the pancreatic $\beta$-cell plasma insulin concentration, SIRT1 activation caused a reduction in body temperature and metabolism (torpor condition) with more long-term effects of weight gain and hepatic steatosis [86].

However, acute knockout of SIRT1 lead to reduction of hyperglycemia setting and an increase of insulin sensitivity by increasing the liver responsiveness to insulin and reducing gluconeogenesis [87, 88]. The results regarding SIRT1 effects on gluconeogenesis and insulin sensitivity seem inconsistent. This discrepancy could be due to the feedback mechanism on the SIRT1-FOXO1 pathway by SHP (encoded by NrOb2) [89]. Furthermore, SIRT1 knockout in healthy mice brings normal fed and fasting blood glucose level [89]. However, SIRT1 knockout in genetic diabetic mice (double knockout on IRS1/2) resulted in better blood glucose level and glucose tolerance, although the mice were still insulin resistant. This implied that SIRT1 activation can be completed in genetically derived diabetic patients or in already diabetic patients. SIRT1 treatment might not be used to prevent people from diabetes.

In general, MSG-induced mice are more related to obese phenomenon. Quite a few involved genes are intertwined with obesity, such as fat metabolism from PPARs family. While high-carbohydrate-induced diabetes can also cause lipogenesis by balancing the excess of carbohydrate into fat, MSG-induced diabetes seems to directly activate lipogenesis. The changes in genes expression triggered by MSG- induced T2D are summarized in Figure 3. 


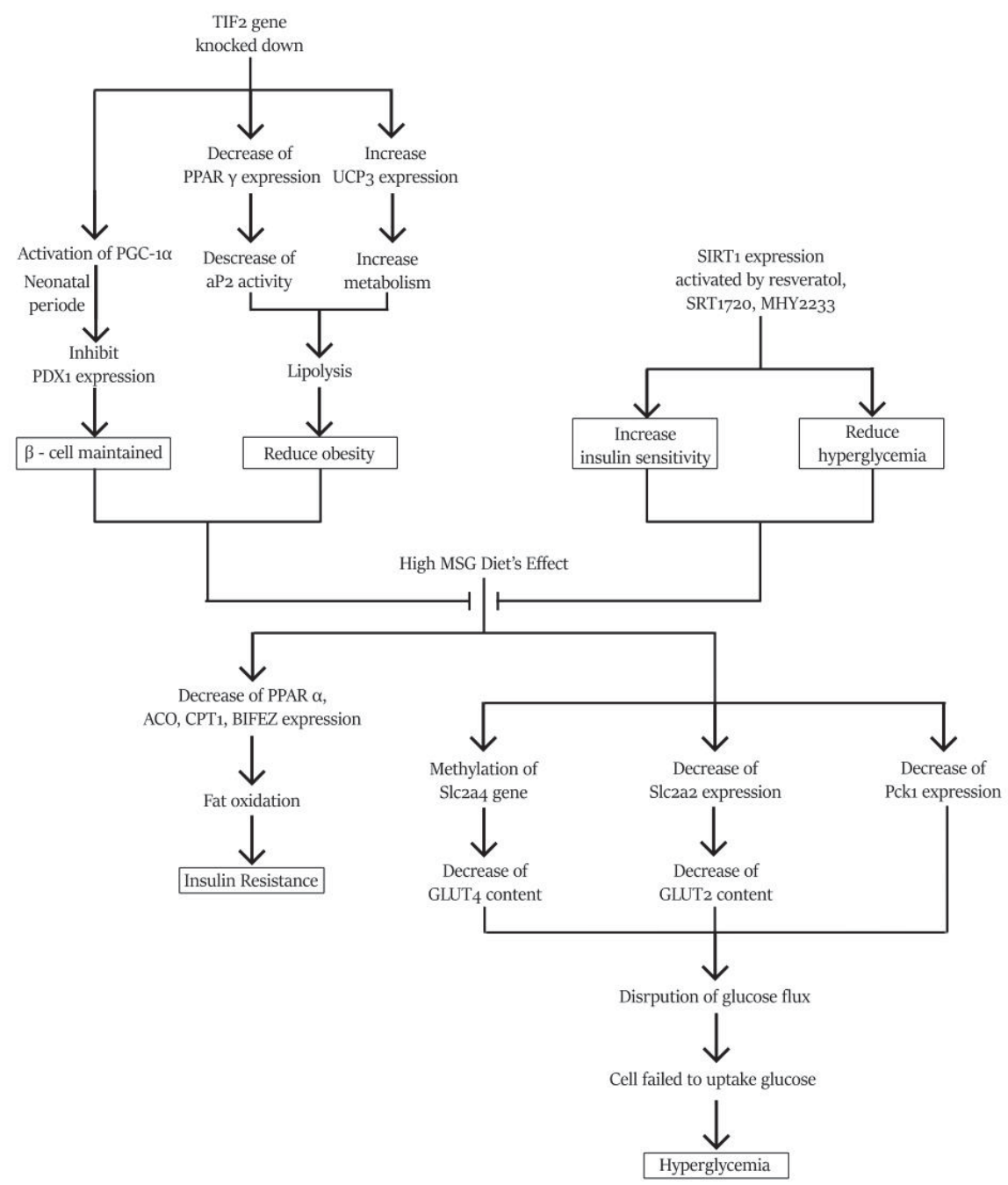

FIGURE 3. Mechanisms of changing genes expression affected by MSG-induced diabetes and of 


\section{Involvement of Genes and Proteins in T2D}

It is important to figure out whether the disruption of the gene expression is the reason for

TABLE 1. Summary of genes involved in diet-induced diabetes

\begin{tabular}{|c|c|c|c|c|c|c|}
\hline \multirow[b]{2}{*}{ Diet } & \multirow[b]{2}{*}{$\begin{array}{l}\text { Gene/ } \\
\text { protein }\end{array}$} & \multirow[b]{2}{*}{ Effect } & \multicolumn{3}{|c|}{ Condition } & \multirow[b]{2}{*}{ Reference } \\
\hline & & & $\begin{array}{c}\text { Changed by } \\
\text { T2D }\end{array}$ & $\begin{array}{c}\text { Affecting } \\
\text { T2D } \\
\text { development }\end{array}$ & N. D & \\
\hline \multirow{5}{*}{$\begin{array}{l}\text { High } \\
\text { carbohy- } \\
\text { drate }\end{array}$} & FoxO1 [protein] & $\begin{array}{l}\text { Dephospho- } \\
\text { rylated }\end{array}$ & & $\checkmark$ & & [13] \\
\hline & Scd1 [gene] & $\begin{array}{l}\text { Increase of } \\
\text { expression }\end{array}$ & & & $\checkmark$ & [36] \\
\hline & ATF4 [gene] & $\begin{array}{l}\text { Increase of } \\
\text { expression }\end{array}$ & & $\checkmark$ & & [48] \\
\hline & $\begin{array}{l}\text { INSIG1 } \\
\text { [gene] }\end{array}$ & $\begin{array}{l}\text { Reduction of } \\
\text { expression }\end{array}$ & & $\checkmark$ & & [90] \\
\hline & $\begin{array}{l}\text { FoxO1 } \\
\text { [gene] }\end{array}$ & $\begin{array}{l}\text { Increase of } \\
\text { expression }\end{array}$ & & $\checkmark$ & & [90] \\
\hline
\end{tabular}




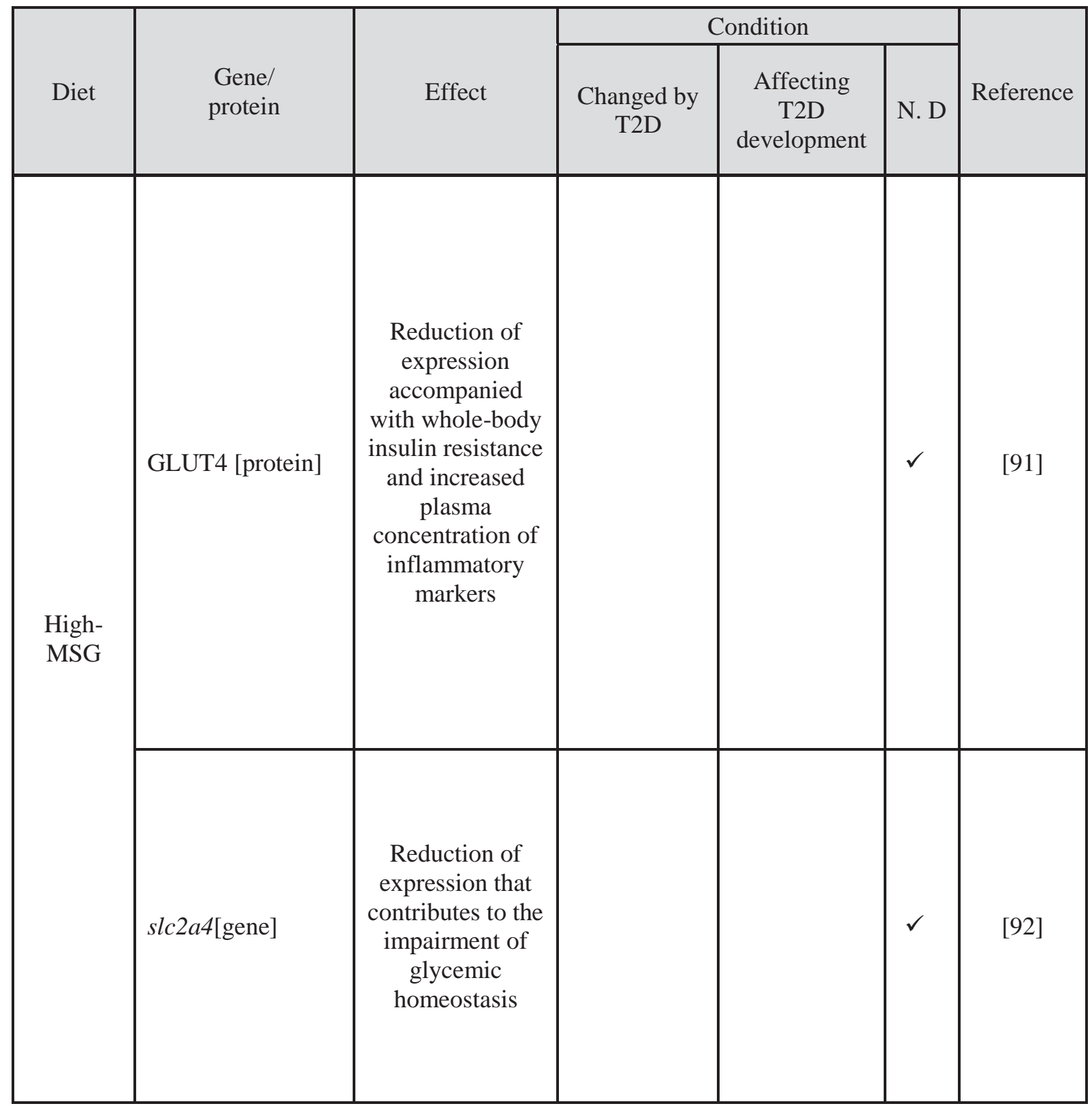




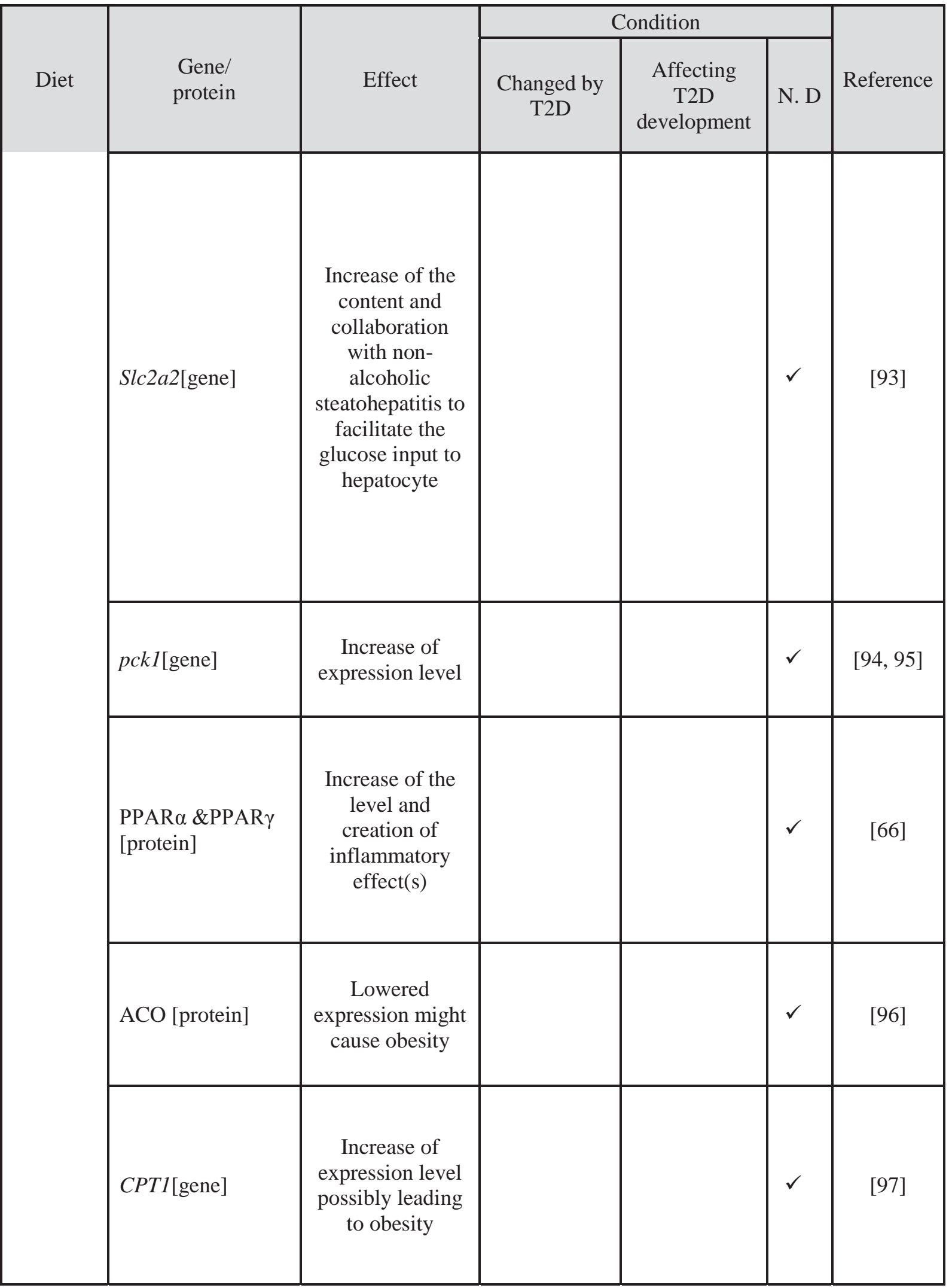




\begin{tabular}{|c|c|c|c|c|c|c|}
\hline \multirow[b]{2}{*}{ Diet } & \multirow[b]{2}{*}{$\begin{array}{l}\text { Gene/ } \\
\text { protein }\end{array}$} & \multirow[b]{2}{*}{ Effect } & \multicolumn{3}{|c|}{ Condition } & \multirow[b]{2}{*}{ Reference } \\
\hline & & & $\begin{array}{c}\text { Changed by } \\
\text { T2D }\end{array}$ & $\begin{array}{c}\text { Affecting } \\
\text { T2D } \\
\text { development }\end{array}$ & N. D & \\
\hline & $P D K 4$ [gene] & $\begin{array}{l}\text { Increase of } \\
\text { muscle PDK4 } \\
\text { expression }\end{array}$ & & & $\checkmark$ & [98] \\
\hline & TIF2[gene] & $\begin{array}{l}\text { Deletion of this } \\
\text { gene protects } \\
\text { mice from obese }\end{array}$ & & & $\checkmark$ & [75] \\
\hline & SRC1[gene] & $\begin{array}{l}\text { antagonist of } \\
\text { TIF2- }\end{array}$ & & & $\checkmark$ & [76] \\
\hline & $P G C-1 \alpha$ & $\begin{array}{l}\text { Activation at } \\
\text { neonatal period } \\
\text { reduced PDX1 } \\
\text { expression and } \\
\text { pancreas } \\
\text { maturation }\end{array}$ & & & $\checkmark$ & [99] \\
\hline & SIRT1 [gene] & $\begin{array}{l}\text { Increase of this } \\
\text { gene expression } \\
\text { alleviates } \\
\text { symptomps in } \\
\text { the already } \\
\text { diabetic patient }\end{array}$ & & & $\checkmark$ & [81] \\
\hline
\end{tabular}




\begin{tabular}{|c|c|c|c|c|c|c|}
\hline \multirow[b]{2}{*}{ Diet } & \multirow[b]{2}{*}{$\begin{array}{l}\text { Gene/ } \\
\text { protein }\end{array}$} & \multirow[b]{2}{*}{ Effect } & \multicolumn{3}{|c|}{ Condition } & \multirow[b]{2}{*}{ Reference } \\
\hline & & & $\begin{array}{l}\text { Changed by } \\
\text { T2D }\end{array}$ & $\begin{array}{c}\text { Affecting } \\
\text { T2D } \\
\text { development }\end{array}$ & N. D & \\
\hline & slc2a4[gene] & $\begin{array}{l}\text { Reduction of } \\
\text { expression that } \\
\text { contributes to the } \\
\text { impairment of } \\
\text { glycemic } \\
\text { homeostasis }\end{array}$ & & & $\checkmark$ & [92] \\
\hline & Slc2a2[gene] & $\begin{array}{l}\text { Increase of the } \\
\text { content and } \\
\text { collaboration } \\
\text { with non- } \\
\text { alcoholic } \\
\text { steatohepatitis to } \\
\text { facilitate the } \\
\text { glucose input to } \\
\text { hepatocyte }\end{array}$ & & & $\checkmark$ & [93] \\
\hline & pck1[gene] & $\begin{array}{c}\text { increase of } \\
\text { expression level }\end{array}$ & & & $\checkmark$ & {$[94,95]$} \\
\hline & $\begin{array}{l}\text { PPAR } \alpha \text { \&PPAR } \gamma \\
\text { [protein] }\end{array}$ & $\begin{array}{l}\text { Increase of the } \\
\text { level and } \\
\text { creation of } \\
\text { inflammatory } \\
\text { effect(s) }\end{array}$ & & & $\checkmark$ & [66] \\
\hline
\end{tabular}




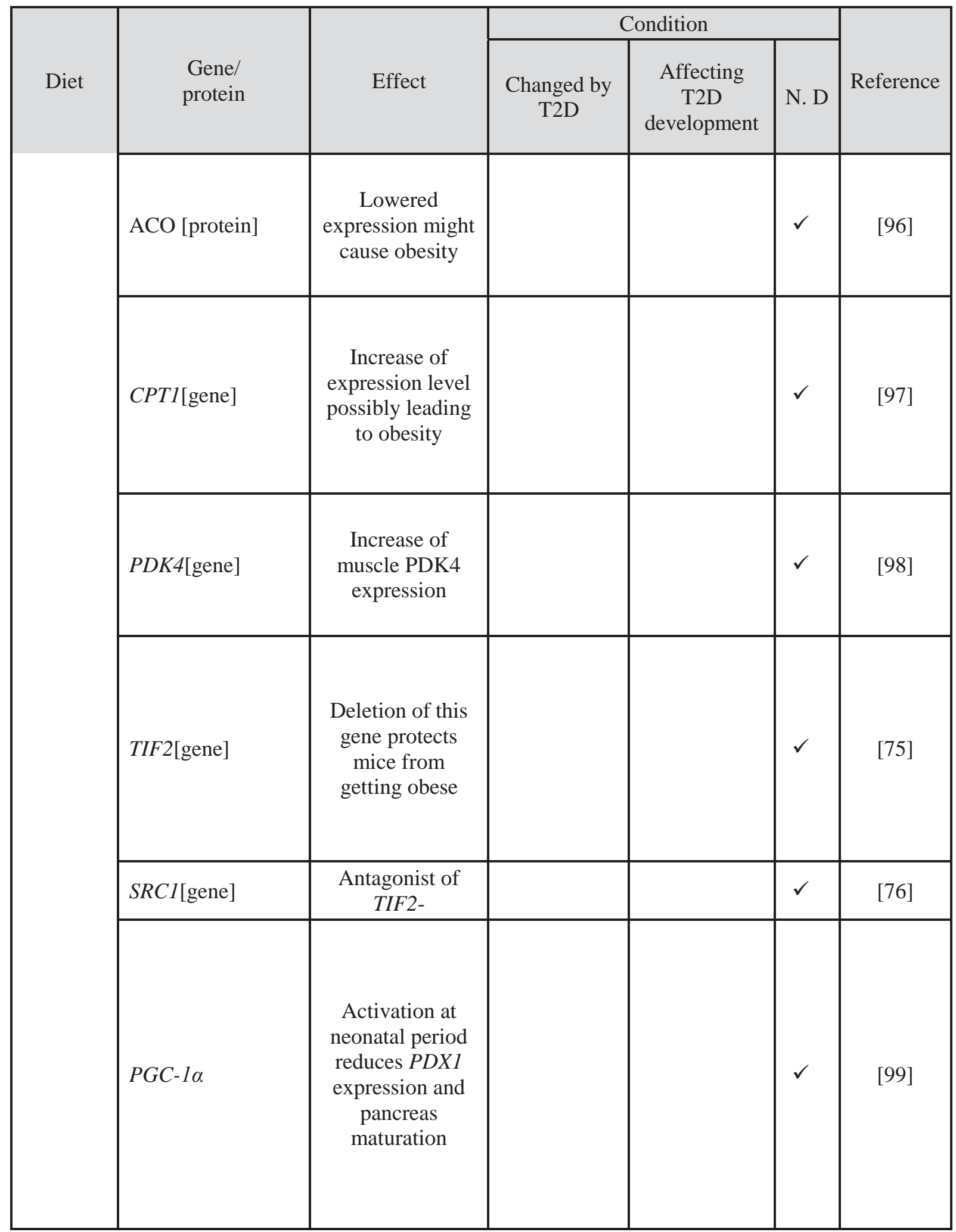




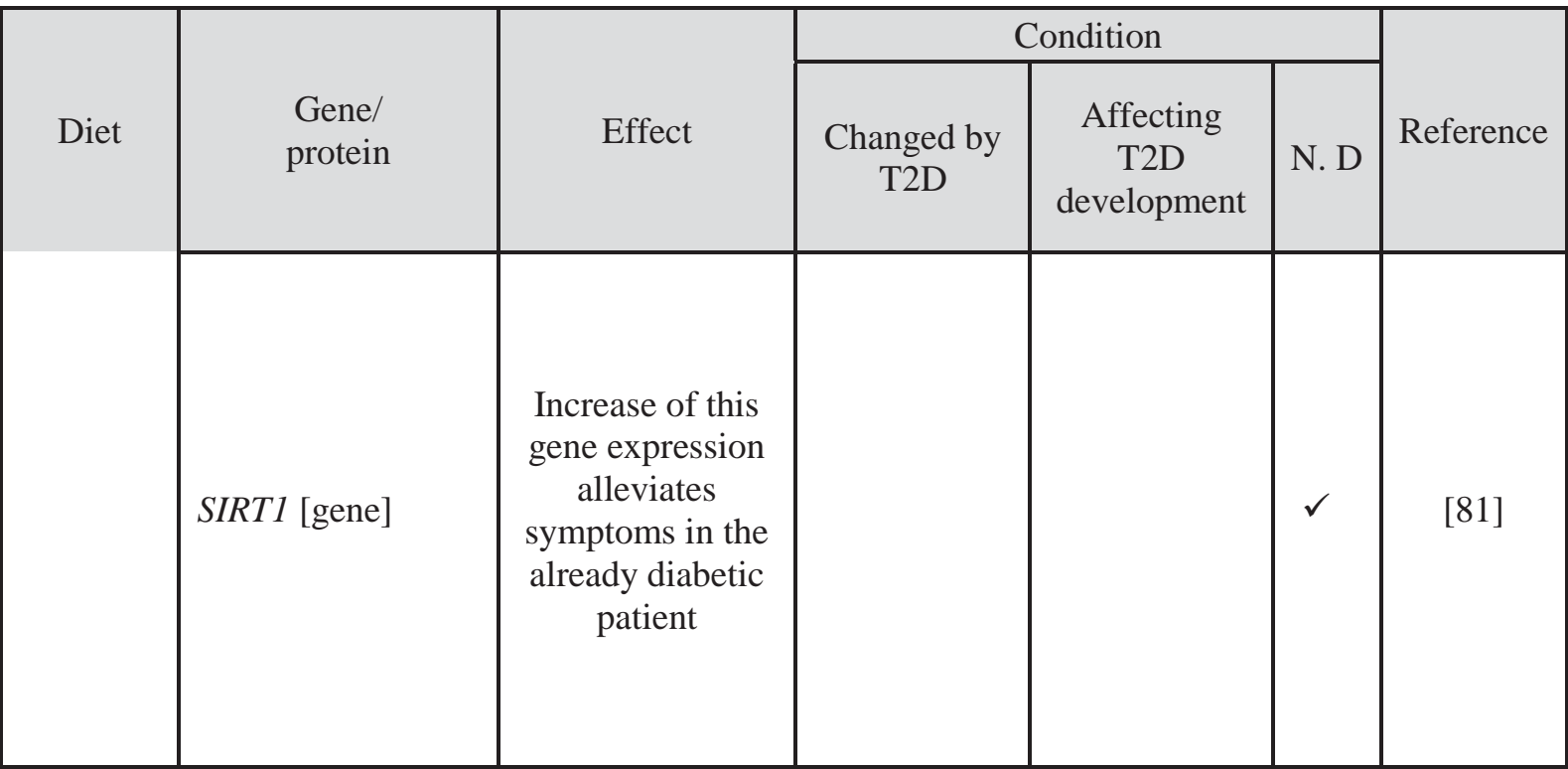

Various genes such as FOXO1, PDX1, ATF4, and INSIG1 proved to be important for the development of $\beta$-pancreas cells, or to maintain the balance of metabolism to increase glucose tolerance. Meanwhile, genes expression alteration that directly corelate with carbohydrate or fat metabolism, such as GLUT families, pck1, scd1, and PPAR are more likely caused by feedback mechanism and complex regulation to give better glucose level performa [60, 97]. Disturbance of expression in genes like ACO, CPT1, TIF2, SRC1, scd1 and UCP3 in muscle cells and adipocyte cells are more into causing obesity, in which these genes are related to fat metabolism and energy expenditure. Caution must be taken that diabetes could also abberated these genes expression directly related to metabolism and disruption of these genes in early stage of development could also cause various physiological imbalances. However, genes like TIF2, SRC1, and PGC-1 $\alpha$ were predicted to be more upstream in the signaling pathway. Thus, modulation of these genes might prevent further physiological abberations related to metabolism imbalances such as obesity and diabetes. SIRT1 expression was not changed by diabetes and its knockout also did not cause T2D. SIRT1 is a promising gene to be targeted in the already diabetic patient as previously stated above. We further hypothesized that based on the animal studies, both highcarbohydrate (found in high glycemic index food or energy-dense food) and introduction of high MSG (by injection) might reinforce each other to increase the prevalence of T2D or other metabolic disorders. The possibility of intervention study employing both factors might be noteworthy to be investigated. 


\section{Population-based Studies of High-carbohydrate and High-MSG Diet}

Using animal and cell line models, high-MSG and high-carbohydrate diets correlated and might also contribute to the onset of T2D by disrupting expression and the activity of various genes mentioned in Table 1. However, studies on epidemiology might support or contrast the idea of the correlation between T2D and high-MSG or high-carbohydrate diet. Various factors contributed to this conditions such as age, ethnicity, genetics, anatomical and metabolic differences, or socioeconomics or even in the experimental design itself [100].

Population study of dietary carbohydrate intake above normal level in Japanese population showed that obese participants develops T2D more readily than non-obese participants. This indicated that large samples, genetic effects, participants' backgrounds should be considered in the epidemiology study [101]. However, epidemiological studies in China, India, United States, and UAE supported the dietary style of high-carbohydrate intake (such as refined grain and added sugar) positively correlated with T2D [18, 102-105]. Another profound study on epidemiology related to the increasing risk of T2D was conducted on sugar-sweetened diet beverages in female US nurses in 1989 [106]. The intake of these high-calorie beverages (such as, soft drink and fruit punch) was said to be associated with the increasing chances of T2D development. More than 60 \% diabetic people live in China and India, followed by Japan [103, 107]. Asian countries, such as China, India or UAE are predicted to yield a higher rate of diabetic prevalence [18, 102-105]. Although general population in Japan consume white rice and MSG-enriched food like people in other Asian countries, uniquely, Japan is projected to have only a small increase in the ratio of its diabetic people in 2025. This fact might be due to the nationwide health guidance and lifestyle intervention program [107-109].

While studies on epidemiology related to high-carbohydrate diet related to the risk of T2D development are clearly [18, 102-105], findings about human population study at risk of highMSG diet are inconsistent. Studies on MSG-related diabetic cases have been frequently reported using animal models. There is a lack of epidemiological data of MSG consumption which contribute to T2D in comparison to those of high-carbohydrate consumption. Epidemiology in Spanish population has been linked to the increasing risks of getting T2D to cardiovascular diseases due to high glutamate plasma level [110]. Based on another epidemiology in Thailand, daily consumption exceeding $5 \mathrm{~g}$ of MSG is considered risky to carry metabolic disorders, 
including T2D [111]. MSG intakes have also been reported to increase the incidence of overweight [112]. However, two studies from the Jiangsu Nutrition Study argued that MSG intake did not correlate with obesity, and even high MSG intake was negatively associated with hyperglycemia $[113,114]$.

One possible explanation that could explain the opposing results among the studies of epidemiology is the unready transportation from the intestine into the blood circulation in contrast to various experimental data that used MSG-induced diabetic mice models by MSG subcutaneous injection [51, 115]. Another explanation arises from experimental data where life period is an important factor related to the genetic programming by environmental factors. Mice at the age of 4 months old with high-MSG diet are prone to various metabolic disorders, including the increased signs of glucose intolerance. However, along with the aging process, the impairment of metabolism from the obesity effects can be attenuated [116].

By considering both experimental data from animal or cell culture studies with epidemiological data, we summarize that high-carbohydrate diet evidently positively correlates with T2D and could cause the onset of T2D. Although MSG studies are still in conflict with one another, we do not encourage people to slacken their diets by consuming high amount of MSG based on the experimental data of MSG potentials to alter homeostasis on carbohydrate and fat metabolism. All in all, lifestyle intervention shows to be a promising primary prevention of diabetes, and healthy lifestyle is shown to be comparable with metformin intake as reported by Indian Diabetes Prevention Programme [104]. Govermental policies can play a huge role on combating the increasing prevalence of diabetes by encouraging a healthy diet and lifestyle, such as taxation program in Thailand for beverages which contain high level of sugar content [117].

\section{Conclusion and Future Perspectives}

High-fat diet is commonly known to induce T2D, especially in the case of highcarbohydrate and high-MSG diets. However, high-MSG diet requires longer time to develop hyperglycemia preceded by obesity. Various genes, especially genes related to glucose and fat metabolism are interrelated within these two diets. Branched signal transduction pathways and different phenotypes of each gene in different organs or ages revealed complicated mechanisms that should be taken as precautions as the targeted gene of interest to treat T2D or to construct a specific biomarker for T2D. Initially, some activated or repressed genes are only a feedback 
mechanism to control body homeostasis related to the imbalanced diet. For example, highcarbohydrate diet increased SCD-1expression. Prolonged feedback mechanism often creates vicious cycle thus developing metabolic syndromes including obesity and T2D.

Increasing FoxO1 and ATF4 expressions or their activation in high-carbohydrate-induced diabetic mice will lead to insulin resistance. It could be interesting to study the repression or the side effects of both genes of diabetic mice for long-term experiments. Both genes might have potential uses as a biomarker for early detection of the T2D. The fact of MSG-induced diabetic mice often leads to the increase of gene expressions related to lipogenesis, such as PPARs family. However, the changes in PPARs expression and activation may disrupt the balance between glucose and lipid metabolism. Both TIF2 and SIRT1 are promising genes in alleviating insulin resistance developed from MSG-induced diabetes. However, these strategies have also exhibited some drawbacks. TIF2 silencing increased the expression of PGC-1 $\alpha$ that inhibited the maturation of pancreas at neonatal period. Further information on TIF2 silencing of pancreatic cells from various ages of mice models may enlighten the benefits of targeting TIF2 as a gene of interest to treating T2D. It is still unclear how the MSG affects the TIF2 expression in $\beta$-cells. Similarly, SIRT1 is indeed an interesting target gene, however, precautions should be taken in drug administration, diet lifestyle, and targeted organs. Otherwise, the disruption of the delicate balance of homeostasis may lead to worsening physical conditions. Studying the SIRT1 signal transduction pathway and its effects on T2D in a more long-term experiment will shed more understanding into how SIRT1 maintains homeostasis.

\section{Acknowledgments}

The research and writing of this paper was funded by Indonesia Ministry of Research, Technology, and Higher Education (021/SP-Lit/LPPM-01/DRPM/Multi/FTB/III/2019). We thank Helen Hendaria Kamandhari, Ph.D. for her editing and comments.

Conflict of interests: All authors have declared that no conflict of interests exists.

Ethical approval: The studies conducted in this article article do not involve human participants or animals.

\section{References}


[1]Cho, N., Shaw, J. E., Karuranga, S., Huang, Y., da Rocha Fernandes, J. D., Ohlrogge, A. W., \& Malanda, B. (2018). IDF Diabetes Atlas: Global estimates of diabetes prevalence for 2017 and projections for 2045. Diabetes research and clinical practice, 138, 271-281.

[2]Das, S. K., \&Elbein, S. C. (2006). The genetic basis of type 2 diabetes. Cellscience, 2(4), 100131.

[3]Jimenez-Chillaron, J. C., Ramon-Krauel, M., Ribo, S., \& Diaz, R. (2015). Transgenerational epigenetic inheritance of diabetes risk as a consequence of early nutritional imbalances. Proceedings of the Nutrition Society, 75(1),78-89.

[4]Alkhatib, A., Tsang, C., Tiss, A., Bahorun, T., Arefanian, H., Barake, R., Khadir, Abdelkrim., danTuomilehto, J. (2017). Functional Foods and Lifestyle Approaches for Diabetes Prevention and Management. Nutrients, 9(12), 1310

[5]Sun, Y., You, W., Almeida, F., Estabrooks, P., \& Davy, B. (2017). The Effectiveness and Cost of Lifestyle Interventions Including Nutrition Education for Diabetes Prevention: A Systematic Review and Meta-Analysis. Journal of the Academy of Nutrition and Dietetics, 117(3), 404421.e36

[6]Kahn, S. E., Hull, R. L., \&Utzschneider, K. M. (2006). Mechanisms linking obesity to insulin resistance and type 2 diabetes. Nature, 444(7121), 840.

[7]Weyer, C., Bogardus, C., Mott, D. M., \& Pratley, R. E. (1999). The natural history of insulin secretory dysfunction and insulin resistance in the pathogenesis of type 2 diabetes mellitus. The Journal of clinical investigation, 104(6), 787-794.

[8]Donath, M. Y., Ehses, J. A., Maedler, K., Schumann, D. M., Ellingsgaard, H., Eppler, E., \& Reinecke, M. (2005). Mechanisms of $\beta$-cell death in type 2 diabetes. Diabetes, 54(suppl 2), S108-S113.

[9]Zimmet, P., Shi, Z., El-Osta, A., \& Ji, L. (2018). Epidemic T2DM, early development and epigenetics: implications of the Chinese Famine. Nature Reviews Endocrinology, 14(12), 738746.

[10]Tian, M., Reichetzeder, C., Li, J., \&Hocher, B. (2019). Low birth weight, a risk factor for diseases in later life, is a surrogate of insulin resistance at birth. Journal of hypertension, 37(11), 2123-2134. 
[11]Gilbert, E. R., Fu, Z., \& Liu, D. (2011). Development of a nongenetic mouse model of type 2 diabetes. Experimental diabetes research, 2011.

[12]Manco, M., Calvani, M., \&Mingrone, G. (2004). Effects of dietary fatty acids on insulin sensitivity and secretion. Diabetes, Obesity and Metabolism, 6(6), 402-413.

[13]Kluth, O., Mirhashemi, F., Scherneck, S., Kaiser, D., Kluge, R., Neschen, S., Joost, H.G., \&Schürmann, A. (2011). Dissociation of lipotoxicity and glucotoxicity in a mouse model of obesity associated diabetes: role of forkhead box O1 (FOXO1) in glucose-induced beta cell failure. Diabetologia, 54(3), 605-616.

[14]Kim, Y. B., Iwashita, S., Tamura, T., Tokuyama, K., \& Suzuki, M. (1995). Effect of high-fat diet on the gene expression of pancreatic GLUT2 and glucokinase in rats. Biochemical and biophysical research communications, 208(3), 1092-1098.

[15]Liu, Z., Patil, I. Y., Jiang, T., Sancheti, H., Walsh, J. P., Stiles, B. L., Yin, F.,\&Cadenas, E. (2015). High-fat diet induces hepatic insulin resistance and impairment of synaptic plasticity. PloSone, 10(5), e0128274.

[16]Putra, S. E. D., Singajaya, S., Thesman, F., Pranoto, D. A., Sanjaya, R., Vianney, Y. M., \& Artadana, I. B. M. (2019). Aberrant PDK4 Promoter Methylation Preceding Hyperglycemia in a Mouse Model. Applied biochemistry and biotechnology, 2019 Oct 26. doi: 10.1007/s12010019-03143-6.

[17]Muthayya, S., Sugimoto, J. D., Montgomery, S., \&Maberly, G. F. (2014). An overview of global rice production, supply, trade, and consumption. Annals of the new york Academy of Sciences, 1324(1), 7-14.

[18]Li, Y., Wang, D. D., Ley, S. H., Vasanti, M., Howard, A. G., He, Y., \& Hu, F. B. (2017). Time trends of dietary and lifestyle factors and their potential impact on diabetes burden in China. Diabetes Care, 40(12), 1685-1694.

[19]Hu, E. A., Pan, A., Malik, V., \& Sun, Q. (2012). White rice consumption and risk of type 2 diabetes: meta-analysis and systematic review. Bmj, 344, e1454.

[20]Mohan, V., Radhika, G., Vijayalakshmi, P., \& Sudha, V. (2010). Can the diabetes/cardiovascular disease epidemic in India be explained, at least in part, by excess refined grain (rice) intake?. The Indian journal of medical research, 131, 369-72. 
[21]Balakumar, M., Raji, L., Prabhu, D., Sathishkumar, C., Prabu, P., Mohan, V., \&Balasubramanyam, M. (2016). High-fructose diet is as detrimental as high-fat diet in the induction of insulin resistance and diabetes mediated by hepatic/pancreatic endoplasmic reticulum (ER) stress. Molecular and cellular biochemistry, 423(1-2), 93-104.

[22]Bizeau, M. E., \&Pagliassotti, M. J. (2005). Hepatic adaptations to sucrose and fructose. Metabolism, 54(9), 1189-1201.

[23]Dirlewanger, M., Schneiter, P., Jéquier, E., \&Tappy, L. (2000). Effects of fructose on hepatic glucose metabolism in humans. American journal of physiology-endocrinology and metabolism, 279(4), E907-E911.

[24]Sasaki, Y., Suzuki, W., Shimada, T., Iizuka, S., Nakamura, S., Nagata, M., Fujimoto, M., Tsuneyama, K., Hokao, R., Miyamoto, K.,\&Aburada, M. (2009). Dose dependent development of diabetes mellitus and non-alcoholic steatohepatitis in monosodium glutamateinduced obese mice. Life sciences, 85(13-14), 490-498.

[25]Morrison, J. F., Shehab, S., Sheen, R., Dhanasekaran, S., Shaffiullah, M., \& Mensah- Brown, E. (2008). Sensory and autonomic nerve changes in the monosodium glutamate- treated rat: a model of type II diabetes. Experimental physiology, 93(2), 213-222.

[26]Nagata, M., Suzuki, W., Iizuka, S., Tabuchi, M., Maruyama, H., Takeda, S., Aburada, M., \& Miyamoto, K. I. (2006). Type 2 diabetes mellitus in obese mouse model induced by monosodium glutamate. Experimental animals, 55(2), 109-115.

[27]Beyreuther, K., Biesalski, H. K., Fernstrom, J. D., Grimm, P., Hammes, W. P., Heinemann, U., Kempski, O., Stehle, P., Steinhart, H.,\& Walker, R. (2007). Consensus meeting: monosodium glutamate-an update. European journal of clinical nutrition, 61(3), 304-313.

[28]Prawirohardjono, W., Dwiprahasto, I., Astuti, I., Hadiwandowo, S., Kristin, E., Muhammad, M., \& Kelly, M. F. (2000). The administration to Indonesians of monosodium L-glutamate in Indonesian foods: an assessment of adverse reactions in a randomized double-blind, crossover, placebo-controlled study. The Journal of nutrition, 130(4), 1074S-1076S.

[29]Srinivasan, M., Aalinkeel, R., Song, F., \& Patel, M. S. (2003). Programming of islet functions in the progeny of hyperinsulinemic/obese rats. Diabetes, 52(4), 984-990. 
[30]Miranda, R. A., da Silva Franco, C. C., de Oliveira, J. C., Barella, L. F., Tófolo, L. P., Ribeiro, T. A., ... \&Lisboa, P. C. (2017). Cross-fostering reduces obesity induced by early exposure to monosodium glutamate in male rats. Endocrine, 55(1), 101-112.

[31]Kitamura, T., Nakae, J., Kitamura, Y., Kido, Y., Biggs, W. H., Wright, C. V., White, M.F., Arden, K.C.,\&Accili, D. (2002). The forkhead transcription factor Foxo1 links insulin signaling to Pdx1 regulation of pancreatic $\beta$ cell growth. The Journal of clinical investigation, 110(12), 1839-1847.

[32]Ahlgren, U., Jonsson, J., Jonsson, L., Simu, K., \&Edlund, H. (1998). $\beta$-Cell-specific inactivation of the mouseIpf1/Pdx 1 gene results in loss of the $\beta$-cell phenotype and maturity onset diabetes. Genes \& development, 12(12), 1763-1768.

[33]Sethi, G., Shanmugam, M. K., \& Kumar, A. P. (2017). SREBP-1c as a molecular bridge between lipogenesis and cell cycle progression of clear cell renal carcinoma. Bioscience reports, 37(6), BSR20171270.

[34]Kim-Muller, J. Y., Kim, Y. J. R., Fan, J., Zhao, S., Banks, A. S., Prentki, M., \&Accili, D. (2016). FoxO1 deacetylation decreases fatty acid oxidation in $\beta$-cells and sustains insulin secretion in diabetes. Journal of Biological Chemistry, 291(19), 10162-10172.

[35]Ntambi, J. M. (1992). Dietary regulation of stearoyl-CoA desaturase 1 gene expression in mouse liver. Journal of Biological Chemistry, 267(15), 10925-10930.

[36]Waters, K. M., \&Ntambi, J. M. (1994). Insulin and dietary fructose induce stearoyl-CoA desaturase 1 gene expression of diabetic mice. Journal of Biological Chemistry, 269(44), 27773-27777.

[37]Ntambi, J. M. (1995). The regulation of stearoyl-CoA desaturase (SCD). Progress in lipid research, 34(2), 139-150.

[38]Pape, M. E., Lopez-Casillas, F., \& Kim, K. H. (1988). Physiological regulation of acetyl-CoA carboxylase gene expression: effects of diet, diabetes, and lactation on acetyl-CoA carboxylase mRNA. Archives of biochemistry and biophysics, 267(1), 104-109.

[39]Rogowski, M. P., Flowers, M. T., Stamatikos, A. D., Ntambi, J. M., \& Paton, C. M. (2013). SCD1 activity in muscle increases triglyceride PUFA content, exercise capacity, and PPAR $\delta$ expression in mice. Journaloflipidresearch, 54(10), 2636-2646. 
[40]Drąg, J., Goździalska, A., Knapik-Czajka, M., Gawędzka, A., Gawlik, K., \&Jaśkiewicz, J. (2017). Effect of high carbohydrate diet on elongase and desaturase activity and accompanying gene expression in rat's liver. Genes \& Nutrition, 12(1),1-8.

[41]Miyazaki, M., Flowers, M. T., Sampath, H., Chu, K., Otzelberger, C., Liu, X., \&Ntambi, J. M. (2007). Hepatic stearoyl-CoA desaturase-1 deficiency protects mice from carbohydrateinduced adiposity and hepatic steatosis. Cell metabolism, 6(6), 484-496.

[42]Gutiérrez-Juárez, Roger., Pocai, Alessandro., Mulas, Claudia., Ono, Hiraku., Bhanot, Sanjay., Monia, Brett P., \& Rossetti, Luciano. (2006). Critical role of stearoyl-CoA desaturase-1 (SCD1) in the onset of diet-induced hepatic insulin resistance. The Journal of Clinical Investigation, 116,1686-1695.

[43]Jiang, G., Li, Z., Liu, F., Ellsworth, K., Dallas-Yang, Q., Wu, M., ... \& Bergeron, R. (2005). Prevention of obesity in mice by antisense oligonucleotide inhibitors of stearoyl-CoA desaturase-1. The Journal of clinical investigation, 115(4), 1030-1038.

[44]Ntambi, J. M., Miyazaki, M., Stoehr, J. P., Lan, H., Kendziorski, C. M., Yandell, B. S., Song, Y., Cohen, P., Friedman, J.M., \&Attie, A. D. (2002). Loss of stearoyl-CoA desaturase-1 function protects mice against adiposity. Proceedings of the National Academy of Sciences, 99(17), 11482-11486.

[45]Flowers, M. T., Ade, L., Strable, M. S., \&Ntambi, J. M. (2012). Combined deletion of SCD1 from adipose tissue and liver does not protect mice from obesity. Journal of Lipid Research, 53(8), 1646-1653.

[46]Li, H., Meng, Q., Xiao, F., Chen, S., Du, Y., Yu, J., Wang, C., \& Guo, F. (2011). ATF4 deficiency protects mice from high-carbohydrate-diet-inducced liver steatosis. Biochemical Journal, 438(2), 283-289.

[47]Seo, J., Fortuno, E. S., Suh, J. M., Stenesen, D., Tang, W., Parks, E. J.,Adams, C.M., Townes, T.,\& Graff, J. M. (2009). Atf4 regulates obesity, glucose homeostasis, and energy expenditure. Diabetes, 58(11), 2565-2573.

[48]Xiao, G., Zhang, T., Yu, S., Lee, S., Calabuig-Navarro, V., Yamauchi, J.,Ringquist, S., \& Dong, H. H. (2013). ATF4 protein deficiency protects against high fructose-induced hypertriglyceridemia in mice. Journal of biological chemistry, 288(35), 25350-25361. 
[49]Li, K., Zhang, J., Yu, J., Liu, B., Guo, Y., Deng, J., Chen, S., Wang, S.,\& Guo, F. (2015). MicroRNA-214 suppresses gluconeogenesis by targeting activating transcriptional factor 4. Journal of Biological Chemistry, 290(13), 8185-8195.

[50]Zhu, X., Li, H., Wu, Y., Zhou, J., Yang, G., \& Wang, W. (2019). lncRNA MEG3 promotes hepatic insulin resistance by serving as a competing endogenous RNA of miR-214 to regulate ATF4 expression. International journal of molecular medicine, 43(1), 345-357.

[51]Burrin, D. G., \& Stoll, B. (2009). Metabolic fate and function of dietary glutamate in the gut. The American journal of clinical nutrition, 90(3), 850S-856S.

[52]Stegink, L. D., Reynolds, W. A., Filer Jr, L. J., Pitkin, R. M., Boaz, D. P., \& Brummel, M. C. (1975). Monosodium glutamate metabolism in the neonatal monkey. American Journal of Physiology-Legacy Content, 229(1), 246-250.

[53]Shannon, M., Wilson, J., Xie, Y., \& Connolly, L. (2019). In vitro bioassay investigations of suspected obesogen monosodium glutamate at the level of nuclear receptor binding and steroidogenesis. Toxicology letters, 301, 11-16.

[54] Kjems, L. L., Holst, J. J., Vølund, A., \&Madsbad, S. (2003). The influence of GLP-1 on glucose-stimulated insulin secretion: effects on $\beta$-cell sensitivity in type 2 and nondiabetic subjects. Diabetes, 52(2), 380-386.

[55]Shannon, M., Green, B., Willars, G., Wilson, J., Matthews, N., Lamb, J., Gillespie, A.,\& Connolly, L. (2017). The endocrine disrupting potential of monosodium glutamate (MSG) on secretion of the glucagon-like peptide-1 (GLP-1) gut hormone and GLP-1 receptor interaction. Toxicology letters, 265, 97-105.

[56] Hotamisligil, G. S., \& Spiegelman, B. M. (1994). Tumor necrosis factor $\alpha$ : a key component of the obesity-diabetes link. Diabetes, 43(11), 1271-1278.

[57]Hotamisligil, G. S., Shargill, N. S., \& Spiegelman, B. M. (1993). Adipose expression of tumor necrosis factor-alpha: direct role in obesity-linked insulin resistance. Science, 259(5091), 8791.

[58]Machado, U. F., Shimizu, Y., \& Saito, M. (1993). Decreased glucose transporter (GLUT 4) content in insulin-sensitive tissues of obese aurothioglucose-and monosodium glutamatetreated mice. Hormone and metabolic research, 25(09), 462-465. 
[59]Yonamine, C. Y., Alves-Wagner, A. B., Esteves, J. V., Okamoto, M. M., Correa-Giannella, M. L., Giannella-Neto, D., \& Machado, U. F. (2019). Diabetes induces tri-methylation at lysine 9 of histone 3 at Slc2a4 gene in skeletal muscle: A new target to improve glycemic control. Molecular and cellular endocrinology, 481, 26-34.

[60]Yonamine, C., Pinheiro-Machado, E., Michalani, M., Alves-Wagner, A., Esteves, J., Freitas, H., \& Machado, U. (2017). Resveratrol improves glycemic control in type 2 diabetic obese mice by regulating glucose transporter expression in skeletal muscle and liver. Molecules, 22(7), 1180.

[61]vio BrandeleroJr, S., ciaBonfleur, M. L., Ribeiro, R. A., Vanzela, E. C., Nassar, C. A., Nassar, P. O., \& Balbo, S. L. (2011). Decreased TNF-a gene expression in periodontal ligature in MSGobese rats: A possible protective effect of hypothalamic obesity against periodontal disease?.Archives of Oral Biology, 57(3): 300-306.

[62]Islam, M. S., \& du Loots, T. (2009). Experimental rodent models of type 2 diabetes: a review. Methods and findings in experimental and clinical pharmacology, 31(4), 249-261.

[63]Hirata, A. E., Andrade, I. S. D., Vaskevicius, P., \&Dolnikoff, M. S. (1997). Monosodium glutamate (MSG)-obese rats develop glucose intolerance and insulin resistance to peripheral glucose uptake. Brazilian journal of medical and biological research, 30, 671-67.

[64]Liu, S. N., Liu, Q., Li, L. Y., Huan, Y., Sun, S. J., \& Shen, Z. F. (2011). Long-term fenofibrate treatment impaired glucose-stimulated insulin secretion and up-regulated pancreatic NF-kappa $\mathrm{B}$ and iNOS expression in monosodium glutamate-induced obese rats: Is that a latent disadvantage?. Journal of translational medicine, 9(1), 176.

[65]Li, P. P., Shan, S., Chen, Y. T., Ning, Z. Q., Sun, S. J., Liu, Q., Lu, X.P., Xie, M.Z.,\& Shen, Z. F. (2006). The PPAR $\alpha / \gamma$ dual agonist chiglitazar improves insulin resistance and dyslipidemia in MSG obese rats. British journal of pharmacology, 148(5), 610-618.

[66]Roman-Ramos, R., Almanza-Perez, J. C., Garcia-Macedo, R., Blancas-Flores, G., FortisBarrera, A., Jasso, E. I., Garcia-Lorenzana, M., Campos-Sepulveda, A.E., Cruz, M., \& Alarcon-Aguilar, F. J. (2011). Monosodium Glutamate Neonatal Intoxication Associated with Obesity in Adult Stage is Characterized by Chronic Inflammation and Increased mRNA 
Expression of Peroxisome Proliferator-Activated Receptors in Mice. Basic \& Clinical Pharmacology \& Toxicology, 108(6), 406-413.

[67]Pan, D. S., Wang, W., Liu, N. S., Yang, Q. J., Zhang, K., Zhu, J. Z., Shan, S., Li, Z.B., Ning, Z.Q., Huang, L.,\& Lu, X. P. (2017). Chiglitazar preferentially regulates gene expression via configuration-restricted binding and phosphorylation inhibition of PPAR $\gamma$.PPAR research, 2017.

[68]Burns, K. A., \& Heuvel, J. P. V. (2007). Modulation of PPAR activity via phosphorylation. Biochimica et Biophysica Acta (BBA)-Molecular and Cell Biology of Lipids, 1771(8), 952-960.

[69]Hu, E., Kim, J. B., Sarraf, P., \& Spiegelman, B. M. (1996). Inhibition of adipogenesis through MAP kinase-mediated phosphorylation of PPAR $\gamma$. Science, 274(5295), 2100-2103.

[70]Lafferty, M. J., Bradford, K. C., Erie, D. A., \&Neher, S. B. (2013). Angiopoietin-like protein 4 inhibition of lipoprotein lipase evidence for reversible complex formation. Journal of Biological Chemistry, 288(40), 28524-28534.

[71]van Otterdijk, S. D., Binder, A. M., vel Szic, K. S., Schwald, J., \&Michels, K. B. (2017). DNA methylation of candidate genes in peripheral blood from patients with type 2 diabetes or the metabolic syndrome. PloSone, 12(7), e0180955.

[72]McAinch, A. J., Cornall, L. M., Watts, R., Hryciw, D. H., O’Brien, P. E., \& Cameron-Smith, D. (2015). Increased pyruvate dehydrogenase kinase expression in cultured myotubes from obese and diabetic individuals. European journal of nutrition, 54(7), 1033-1043.

[73]Georgiadi, A., Lichtenstein, L., Degenhardt, T., Boekschoten, M., van Bilsen, M., Desvergne, B., Müller, M., \& Kersten, S. (2009). Induction of Cardiac Angptl4 by Dietary Fatty Acids IsMediated by Peroxisome Proliferator-Activated Receptor $\beta / \delta$ and Protects Against Fatty Acid-InducedOxidative Stress. Circulation Research, 106(11): 1712-1721

[74]Chokkalingam, K., Jewell, K., Norton, L., Littlewood, J., Van Loon, L. J. C., Mansell, P., Macdonald, I.A., \&Tsintzas, K. (2007). High-fat/low-carbohydrate diet reduces insulinstimulated carbohydrate oxidation but stimulates nonoxidative glucose disposal in humans: an important role for skeletal muscle pyruvate dehydrogenase kinase 4. The Journal of Clinical Endocrinology \& Metabolism, 92(1), 284-292. 
[75]Picard, F., Géhin, M., Annicotte, J. S., Rocchi, S., Champy, M. F., O'Malley, B. W., Chambon, P., \&Auwerx, J. (2002). SRC-1 and TIF2 control energy balance between white and brown adipose tissues. Cell, 111(7), 931-941.

[76]Duteil, D., Chambon, C., Ali, F., Malivindi, R., Zoll, J., Kato, S., Geny, B., Chambon, P.,\& Metzger, D. (2010). The transcriptional coregulators TIF2 and SRC-1 regulate energy homeostasis by modulating mitochondrial respiration in skeletal muscles. Cell metabolism, 12(5), 496-508.

[77]Tiraby, C., Tavernier, G., Capel, F., Mairal, A., Crampes, F., Rami, J., Pujol, C., Boutin, J.A.,\&Langin, D. (2007). Resistance to high-fat-diet-induced obesity and sexual dimorphism in the metabolic responses of transgenic mice with moderate uncoupling protein 3 overexpression in glycolytic skeletal muscles. Diabetologia, 50(10), 2190-2199.

[78]Besseiche, A., Riveline, J. P., Gautier, J. F., Breant, B., \&Blondeau, B. (2015). Metabolic roles of PGC-1 $\alpha$ and its implications for type 2 diabetes. Diabetes \& metabolism, 41(5), 347-357.

[79]Coste, A., Louet, J. F., Lagouge, M., Lerin, C., Antal, M. C., Meziane, H.,Schoonjans, K., Puigserver, P., O'Malley, B.W., \&Auwerx, J. (2008). The genetic ablation of SRC-3 protects against obesity and improves insulin sensitivity by reducing the acetylation of PGC$1 \alpha$. Proceedings of the national academy of sciences, 105(44), 17187-17192.

[80]Valtat, B., Riveline, J. P., Zhang, P., Singh-Estivalet, A., Armanet, M., Venteclef, N., Besseiche, A., Kelly, D.P., Tronche, F., Ferré, P., Gautier, J.F., Bréant, B.,\& Gautier, J. F. (2013). Fetal PGC-1 $\alpha$ overexpression programs adult pancreatic $\beta$-cell dysfunction. Diabetes, 62(4), 1206-1216.

[81]Cao, Y., Jiang, X., Ma, H., Wang, Y., Xue, P., \& Liu, Y. (2016). SIRT1 and insulin resistance. Journal of Diabetes and its Complications, 30(1), 178-183.

[82]Yoshizaki, T., Schenk, S., Imamura, T., Babendure, J. L., Sonoda, N., Bae, E. J., Oh, D.Y., Lu, M., Milne, J.C., Westphal, C., Bandyopadhyay, G.,\& Bandyopadhyay, G. (2009). SIRT1 inhibits inflammatory pathways in macrophages and modulates insulin sensitivity. American journal of physiology-endocrinology and metabolism, 298(3), E419-E428. 
[83]Wang, R. H., Kim, H. S., Xiao, C., Xu, X., Gavrilova, O., \& Deng, C. X. (2011). Hepatic Sirt1 deficiency in mice impairs mTorc2/Akt signaling and results in hyperglycemia, oxidative damage, and insulin resistance. The Journal of clinical investigation, 121(11), 4477-4490.

[84]Kim, M. J., An, H. J., Kim, D. H., Lee, B., Lee, H. J., Ullah, S.,Kim, S.J., Jeong, H.O., Moon, K.M., Lee, E.K., Yang, J., Akter, J., Chun, P., Moon, H.R.,\& Yang, J. (2018). Novel SIRT1 activator MHY2233 improves glucose tolerance and reduces hepatic lipid accumulation in db/db mice. Bioorganic \& medicinal chemistry letters, 28(4), 684-688.

[85]Yamazaki, Y., Usui, I., Kanatani, Y., Matsuya, Y., Tsuneyama, K., Fujisaka, S., Bukhari, A., Suzuki, H., Senda, S., Imanishi, S., Hirata, K., Ishiki, M., Hayashi, R., Urakaze, M., Nemoto, H., Kobayashi, M., \& Hirata, K. (2009). Treatment with SRT1720, a SIRT1 activator, ameliorates fatty liver with reduced expression of lipogenic enzymes in MSG mice. American Journal of Physiology-Endocrinology and Metabolism, 297(5), E1179-E1186.

[86]Gilbert, R. E., Thai, K., Advani, S. L., Cummins, C. L., Kepecs, D. M., Schroer, S. A., Woo, M., \& Zhang, Y. (2015). SIRT1 activation ameliorates hyperglycaemia by inducing a torporlike state in an obese mouse model of type 2 diabetes. Diabetologia, 58(4), 819-827.

[87]Erion, D. M., Yonemitsu, S., Nie, Y., Nagai, Y., Gillum, M. P., Hsiao, J. J., Iwasaki, T., Stark, R., Weismann, D., Yu, X.X., Murray, S.F., Bhanot, S., Monia, B.P., Horvath, T.L., Gao, Q., Samuel, V.T., \& Murray, S. F. (2009). SIRT1 knockdown in liver decreases basal hepatic glucose production and increases hepatic insulin responsiveness in diabetic rats. Proceedings of the National Academy of Sciences, 106(27), 11288-11293.

[88]Rodgers, J. T., \&Puigserver, P. (2007). Fasting-dependent glucose and lipid metabolic response through hepatic sirtuin 1. Proceedings of the National Academy of Sciences, 104(31), 12861-12866.

[89]Wei, D., Tao, R., Zhang, Y., White, M. F., \& Dong, X. C. (2010). Feedback regulation of hepatic gluconeogenesis through modulation of SHP/Nr0b2 gene expression by Sirt1 and FoxO1. American Journal of Physiology-Endocrinology and Metabolism, 300(2), E312-E320.

[90]Sud, N., Zhang, H., Pan, K., Cheng, X., Cui, J., \& Su, Q. (2017). Aberrant expression of microRNA induced by high-fructose diet: implications in the pathogenesis of hyperlipidemia 
and hepatic insulin resistance. The Journal of Nutritional Biochemistry, 43, 125-131. doi:10.1016/j.jnutbio.2017.02.003

[91]Leguisamo, N. M., Lehnen, A. M., Machado, U. F., Okamoto, M. M., Markoski, M. M., Pinto, G. H., \& Schaan, B. D. (2012). GLUT4 content decreases along with insulin resistance and high levels of inflammatory markers in rats with metabolic syndrome. Cardiovascular Diabetology, 11(1), 100.

[92]Poletto, A. C., David-Silva, A., Yamamoto, A. P. de M., Machado, U. F., \& Furuya, D. T. (2015). Reduced Slc2a4/GLUT4 expression in subcutaneous adipose tissue of monosodium glutamate obese mice is recovered after atorvastatin treatment. Diabetology \& Metabolic Syndrome, 7(1), 18.

[93] Silva A.D.,Favaro R.R, Furuya D.T., Silva P.E., Belpiede L.T., Freitas H.S., Okamoto M.M., Barrance F., Zorn T.M.T., Machado U.F. (2015). Overexpression of GLUT2/ Slc2a2 are accompanied by Hnf- $1 \alpha$, Hnf-4 $\alpha$ and Hnf-3 $\beta$ transcriptional, Journal of Liver, 4(3).

[94]Collison, K. S., Zaidi, M. Z., Saleh, S. M., Makhoul, N. J., Inglis, A., Burrows, J., Araujo, J.A., \& Al-Mohanna, F. A. (2011). Nutrigenomics of hepatic steatosis in a feline model: effect of monosodium glutamate, fructose, and Trans-fat feeding. Genes \& Nutrition, 7(2), 265-280.

[95]Beale, E. G., Hammer, R. E., Antoine, B., \& Forest, C. (2004). Disregulatedglyceroneogenesis: PCK1 as a candidate diabetes and obesity gene. Trends in Endocrinology \& Metabolism, 15(3), 129-135.

[96]Collison, K. S., Maqbool, Z., Saleh, S. M., Inglis, A., Makhoul, N. J., Bakheet, R., Al-Johi, M., Al-Rabiah, R., Zaidi, M.Z., \&Al-Mohanna, F. A. (2008). Effect of dietary monosodium glutamate ontransfat-induced nonalcoholic fatty liver disease. Journal of Lipid Research, 50(8), 1521-1537.

[97]Collison, K. S., Makhoul, N. J., Zaidi, M. Z., Inglis, A., Andres, B. L., Ubungen, R., Saleh, S., \& Al-Mohanna, F. A. (2013). Prediabetic changes in gene expression induced by aspartame and monosodium glutamate in Trans fat-fed C57Bl/6 J mice. Nutrition \& Metabolism, 10(1), 44. 
[98]Collison, K. S., Maqbool, Z. M., Inglis, A. L., Makhoul, N. J., Saleh, S. M., Bakheet, R. H., Al-Johi, M.A., Al-Rabiah, R.K., Zaidi, M.Z., \& Al-Mohanna, F. A. (2010). Effect of Dietary Monosodium Glutamate on HFCS-Induced Hepatic Steatosis: Expression Profiles in the Liver and Visceral Fat. Obesity, 18(6), 1122-1134.

[99]Wu, H., Deng, X., Shi, Y., Su, Y., Wei, J., Duan, H. (2016). PGC-1 $\alpha$, glucose metabolism and type 2 diabetes mellitus. J. Endocrinol, 229(3), R99-R115.

[100]Zheng, Y., Ley, S. H., \& Hu, F. B. (2018). Global aetiology and epidemiology of type 2 diabetes mellitus and its complications. Nature Reviews Endocrinology, 14(2), 88.

[101]Sakurai, M., Nakamura, K., Miura, K., Takamura, T., Yoshita, K., Nagasawa, S. Y., ... \&Nakagawa, H. (2016). Dietary carbohydrate intake, presence of obesity and the incident risk of type 2 diabetes in Japanese men. Journal of diabetes investigation, 7(3), 343-351.

[102]Khawaja, A., Qassim, S., Hassan, N., \& Arafa, E. S. A. (2019). Added sugar: Nutritional knowledge and consumption pattern of a principal driver of obesity and diabetes among undergraduates in UAE. Diabetes \& Metabolic Syndrome: Clinical Research \& Reviews, 13(4), 2579-2584

[103]Nanditha, A., Ma, R. C., Ramachandran, A., Snehalatha, C., Chan, J. C., Chia, K. S., Shaw, J.E., \&Zimmet, P. Z. (2016). Diabetes in Asia and the Pacific: implications for the global epidemic. Diabetes care, 39(3), 472-485.

[104]Ramachandran, A., Snehalatha, C., Mary, S., Mukesh, B., Bhaskar, A. D., \& Vijay, V. (2006). The Indian Diabetes Prevention Programme shows that lifestyle modification and metformin prevent type 2 diabetes in Asian Indian subjects with impaired glucose tolerance (IDPP1). Diabetologia, 49(2), 289-297.

[105]Gross, L. S., Li, L., Ford, E. S., \& Liu, S. (2004). Increased consumption of refined carbohydrates and the epidemic of type 2 diabetes in the United States: an ecologic assessment. The American journal of clinical nutrition, 79(5), 774-779.

[106] Schulze, M. B., Manson, J. E., Ludwig, D. S., Colditz, G. A., Stampfer, M. J., Willett, W. C., \& Hu, F. B. (2004). Sugar-sweetened beverages, weight gain, and incidence of type 2 diabetes in young and middle-aged women. Jama, 292(8), 927-934. 
[107]Chan, J. C., Malik, V., Jia, W., Kadowaki, T., Yajnik, C. S., Yoon, K. H., \& Hu, F. B. (2009). Diabetes in Asia: epidemiology, risk factors, and pathophysiology. Jama, 301(20), 2129-2140.

[108]Tsushita, K., Hosler, A. S., Miura, K., Ito, Y., Fukuda, T., Kitamura, A., \&Tatara, K. (2017). Rationale and descriptive analysis of specific health guidance: the nationwide lifestyle intervention program targeting metabolic syndrome in Japan. Journal of atherosclerosis and thrombosis, 42010.

[109]Kosaka, K., Noda, M., \&Kuzuya, T. (2005). Prevention of type 2 diabetes by lifestyle intervention: a Japanese trial in IGT males. Diabetes research and clinical practice, 67(2), $152-162$.

[110]Liu, X., Zheng, Y., Guasch-Ferré, M., Ruiz-Canela, M., Toledo, E., Clish, C., Liang, L., Razquin, C., Corella, D., Estruch, R., Fito, M., Gómez-Gracia, E., Arós, F., Ros, E., Lapetra, J., Fiol, M., Serra-Majem, L., Papandreou, C.,Martínez-González, M.A.,Hu, F.B., \&SalasSalvadó, J. (2019). High plasma glutamate and low glutamine-to-glutamate ratio are associated with Type 2 Diabetes: case-cohort study within the PREDIMED trial. Nutrition, Metabolism and Cardiovascular Diseases, 29(10), 1040-1049.

[111]Insawang, T., Selmi, C., Cha'on, U., Pethlert, S., Yongvanit, P., Areejitranusorn, P., Boonsiri, P., Khampitak, T., Tangrassameeprasert, R., Pinitsoontorn, C., Prasongwattana, V., Gershwin, M.E.,\&Prasongwattana, V. (2012). Monosodium glutamate (MSG) intake is associated with the prevalence of metabolic syndrome in a rural Thai population. Nutrition \& metabolism, 9(1), 50.

[112] He, K., Du, S., Xun, P., Sharma, S., Wang, H., Zhai, F., \& Popkin, B. (2011). Consumption of monosodium glutamate in relation to incidence of overweight in Chinese adults: China Health and Nutrition Survey (CHNS). The American journal of clinical nutrition, 93(6), 13281336.

[113]Shi, Z., Luscombe-Marsh, N. D., Wittert, G. A., Yuan, B., Dai, Y., Pan, X., \& Taylor, A. W. (2010). Monosodium glutamate is not associated with obesity or a greater prevalence of weight gain over 5 years: findings from the Jiangsu Nutrition Study of Chinese adults. British journal of nutrition, 104(3), 457-463. 
[114]Shi, Z., Taylor, A. W., Yuan, B., Zuo, H., \&Wittert, G. A. (2014). Monosodium glutamate intake is inversely related to the risk of hyperglycemia. Clinical nutrition, 33(5), 823-828.

762 [115] Brosnan, J. T., Drewnowski, A., \& Friedman, M. I. (2014). Is there a relationship between dietary MSG obesity in animals or humans?Amino acids, 46(9), 2075-2087.

[116] Hernández-Bautista, R., Alarcón-Aguilar, F., Escobar-Villanueva, D. C., Almanza-Pérez, J., Merino-Aguilar, H., Fainstein, M., \& López-Diazguerrero, N. (2014). Biochemical alterations during the obese-aging process in female and male monosodium glutamate (MSG)-treated mice. International journal of molecular sciences, 15(7), 11473-11494.

[117]Chavasit, V., Kriengsinyos, W., Photi, J., \&Tontisirin, K. (2017). Trends of increases in potential risk factors and prevalence rates of diabetes mellitus in Thailand. European journal of clinical nutrition, 71(7), 839. 
When revising your work, please submit a list of changes or a rebuttal against each point which is being raised when you submit the revised manuscript.

Your revision is due by 25 Feb 2020.

You will see a menu item called 'Submissions Needing Revision'. You will find your submission record there.

Please make sure to submit your editable source files (i.e. Word, tex).

Yours sincerely,

Sebastiano Filetti

Editor-in-Chief

Endocrine

\section{COMMENTS FOR THE AUTHOR:}

Reviewer \#1: 1- MSG (monosodium glutamate) as an abbreviation should be spelled out in the title as well as the abstract and should be added into the abbreviation list. Moreover, MSG should be spelled out when it is first mentioned then only MSG and not monosodium glutamate should be used later. This should be done for all the used abbreviations.

Reply: MSG and T2D in the title, and abstract have been prolonged for the first time However, for the gene name, we still use the abbreviations.

2- The manuscript should be revised for linguistic and grammatical mistakes as well as typographical errors e.g. the authors (in the abstract), dephosphorilation of FoxO1 (in Figure 1) and in page 5 line 119 "Scd1 deficient alone ..." should be "Scd1 deficiency alone ...".

Reply: We are grateful for the input. We change the figure 1 also ask Mrs Helen to recheck and do some proofread on the manuscript.

3- The authors stated that high carbohydrate diet plus high intake of MSG contribute to the emergence of type 2 diabetes. The authors should differentiate between correlation and causation. The authors should show which studies revealed only that the prevalence of type 2 diabetes is correlated with high carbohydrate diet and high intake of MSG and which studies investigated the possibility that high carbohydrate diet and high intake of MSG could lead to type 2 diabetes.

Reply: we deleted the sentence "both factors combine to increase risk of T2D" in the introduction. We noticed that we have to tone down this sentence. Therefore, we just put this as hypothesis that might be interesting to be investigated in animal studies in the last paragraph in the genetic aspects section (before entering human population study).

For genetic aspects, such as in Table 1, we already wrote that for genes which affects T2D development, it is highly probable that disruption of those genes by imbalance diet could lead to the onset of hyperglycemia. As for changed by T2D, then the hyperglycemic period happen first that lead to the change to gene expression. However, indeed many genes are still on the side of N.D., which is the there is missing link on the time period of the activation of the phenotypes. Meanwhile, it can be also caused by a feedback loop from the activation / suppression of the genes itself that create vicious cycle. Also to give balance to the 
experimental data, we then added a new section about human-population study. This will describe more about the correlation between lifestyle and diet to the metabolic disorders. We also added several sentences in the MSG section and in the epidemiology studies that highlighted the main difference in the treatment for MSG case, in which in various animal, genetic, and experimental studies, the model was created by MSG injection, and not by feeding.

4- Are there any studies showing non-significant correlation between the prevalence of type 2 diabetes is and high carbohydrate diet as well as high intake of MSG? You should show all relevant studies!!

Reply: We added some results from epigenetic studies related to the onset of T2D due to highcarbohydrate and high-MSG diet. We also added a new section related to a more comprehensive epidemiological data so that the experimental data can be compared with population-based study and gave a bigger picture of the status quo on both high-carbo and high-MSG. Indeed, despites various factors plays in the epidemiological study, major results for high-carbohydrate is that high-carbohydrate diet is positively correlated with diabetes and could also gave rise to diabetes for a healthy patient. But for highMSG diet, many results are in conflict to each other. We also tried to give some explanation to this in the new section and also in the first paragraph of the impact of MSG by describing the fate of MSG in the gut and why MSG can be considered GRAS as food additive.

5- It would be great if the authors can explain the strategy they used to pick up the genes to be discussed in this review.

Reply: New sentences are added in the last paragraph of the introduction to explain basic ideas on how we screen some genes and gather the articles to assign the review.

6- I suggest adding a small paragraph about the fate (absorption and metabolism) of MSG after its ingestion.

Reply: A new paragraph is added in the impact of MSG section as its first paragraph (line 173-179). There, we describe how MSG can be considered GRAS as food additive We also added a new paragraph after the section to differentiate that various genetic and experimental data employed either MSG injection (subcutan or peritoneal) or by cell culture not by feeding.

7- The authors should also mention epigenetic mechanism leading to insulin resistance by referring to: $\mathrm{J}$ Hypertens. 2019;37(11):2123-2134. doi:10.1097/HJH.0000000000002156. Is something known about epigenetic mechanisms of High-Carbohydrate and High-MSG Diet induced insulin resistance?

Reply: Epigenetic experimental data have been added in the introduction, such as famine, related to low birth weight, imbalance diet, fetal programming by impaired maternal.

8- In Figure 3, what is the relation between the factors in the upper part of the figure and the term "MSG induced".

Reply: it has been corrected to

9- The authors should spell out MSG in the title. In general, use rather full names then abbreviations.

Reply : It is corrected. 


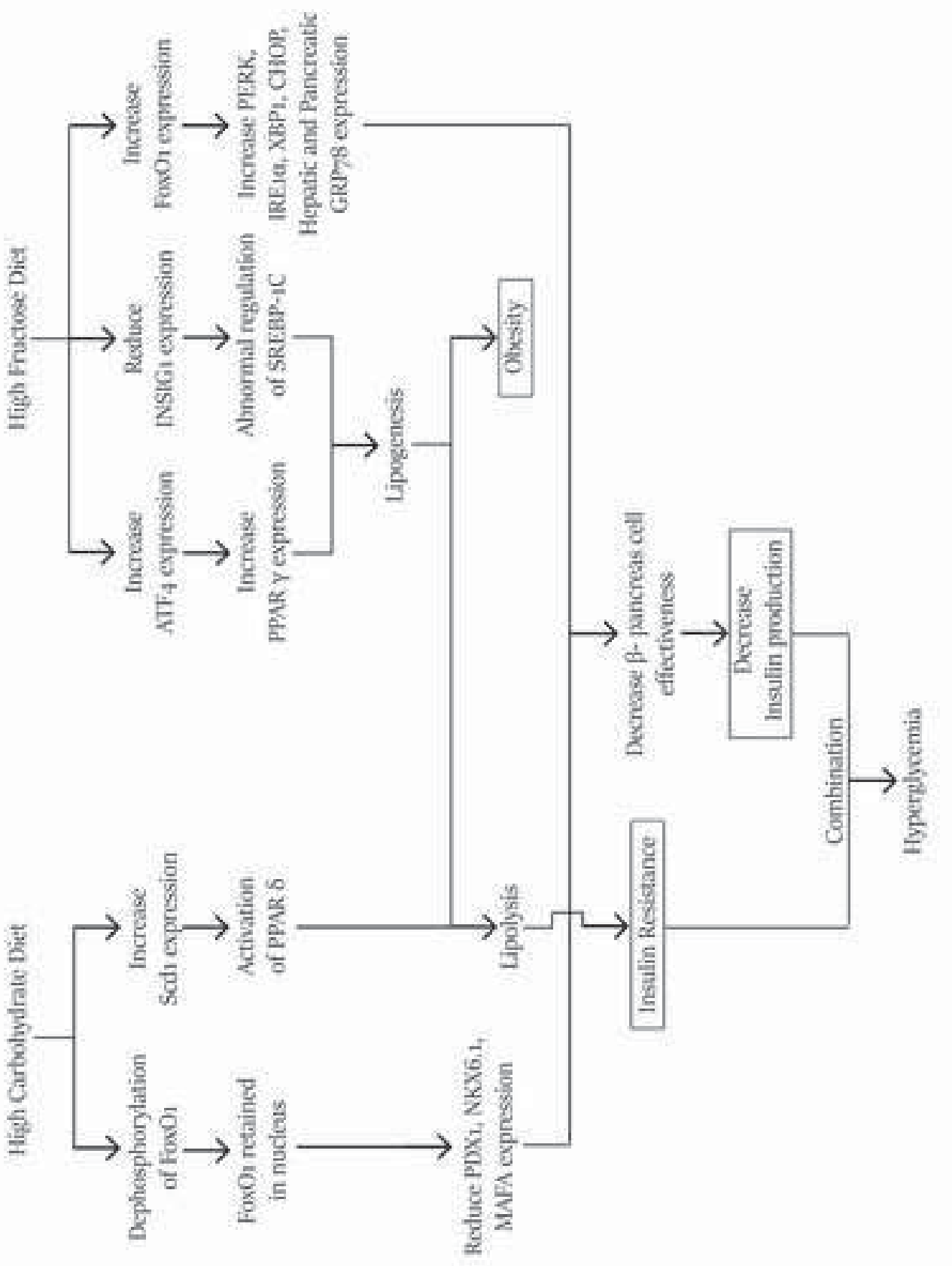


High MSG Diet

neonatal

periode

$\downarrow$

Increase PPAR $\gamma$,

PPAR $\alpha$ expression
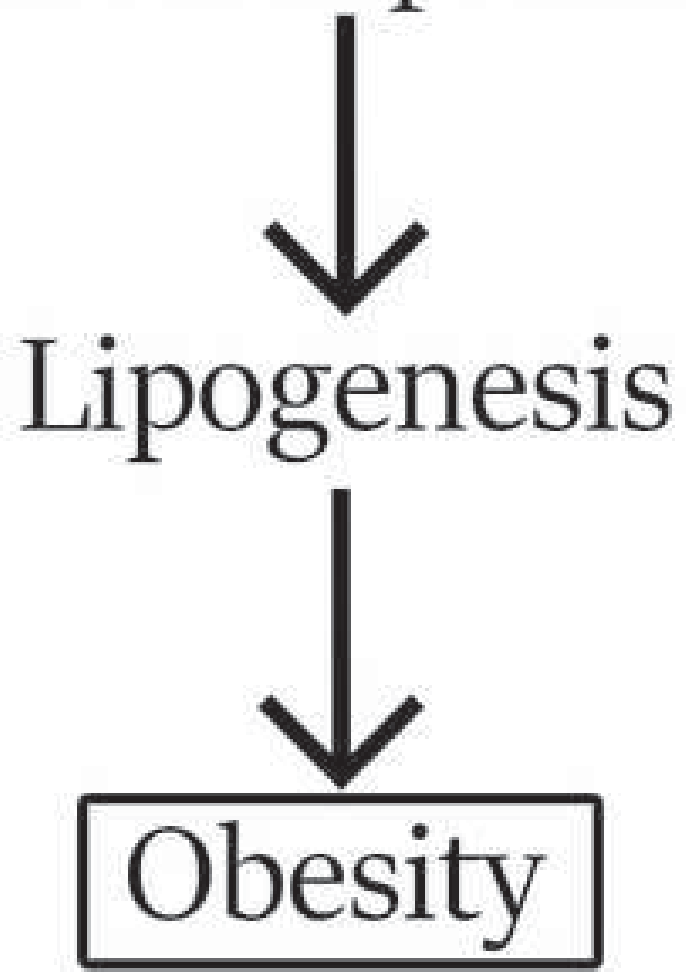


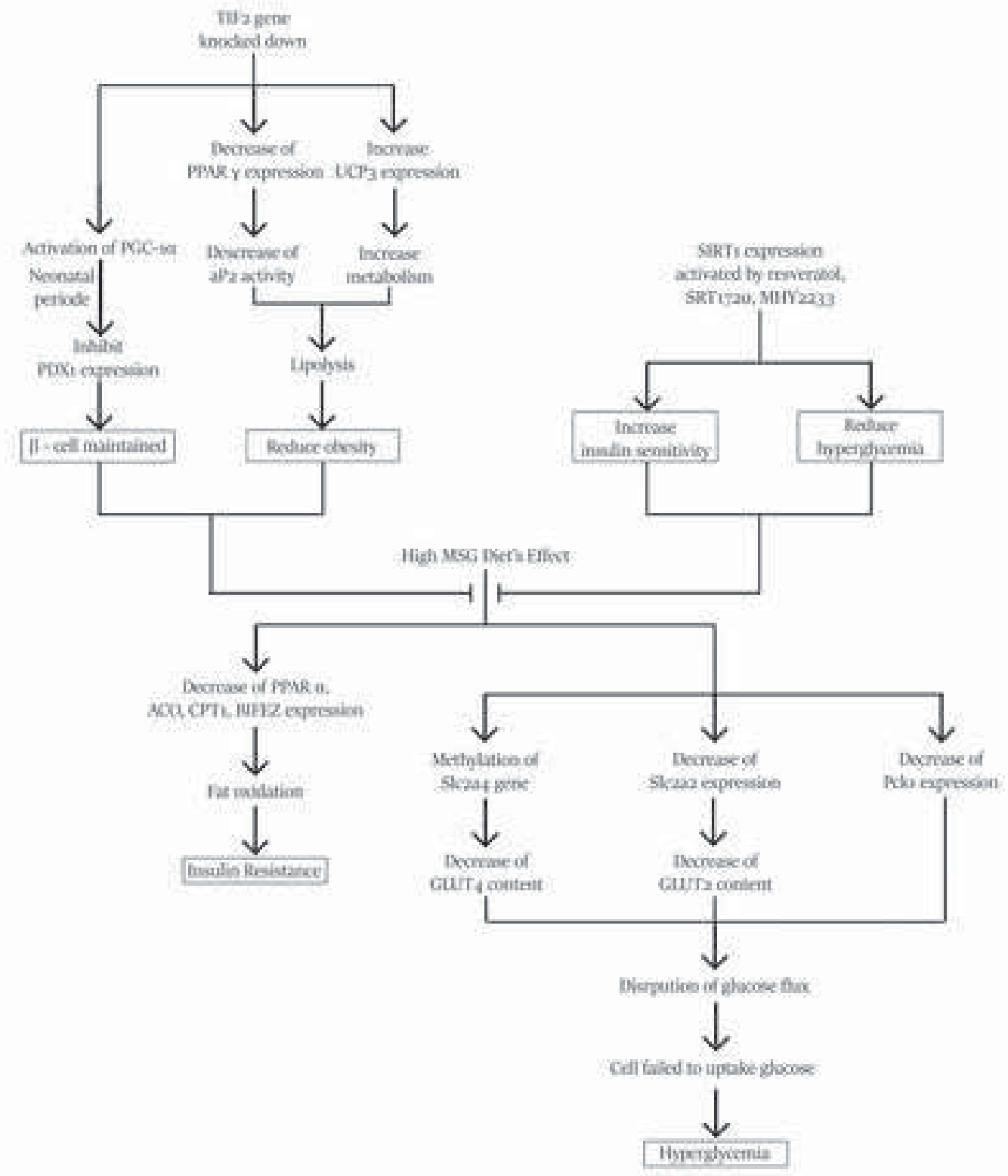



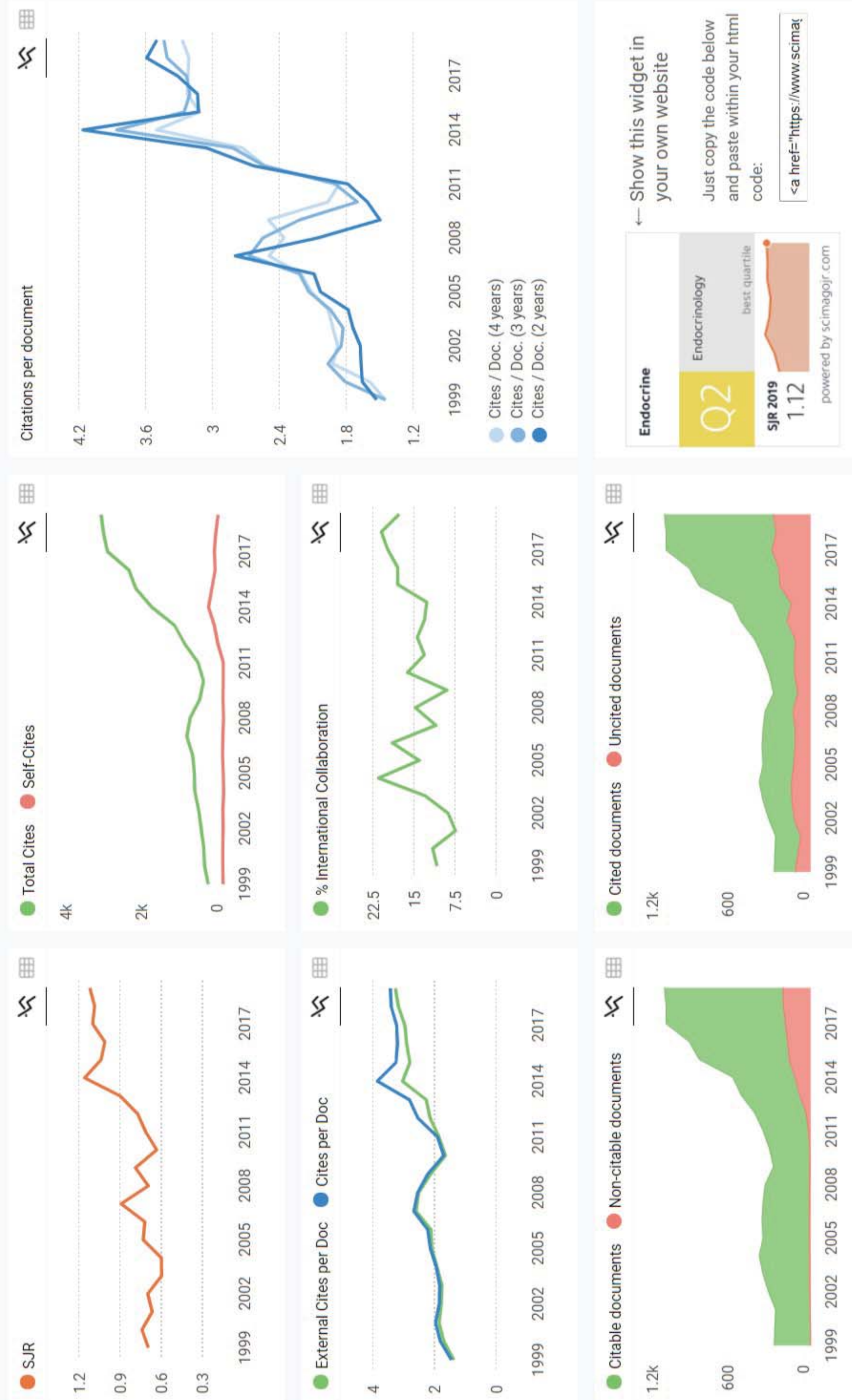


\title{
The genetic basis of high-carbohydrate and high-monosodium glutamate diet related to the increase of likelihood of type 2 diabetes mellitus: a review
}

\author{
Joshua Nathanael ${ }^{1} \cdot$ Hans Cristian Adhinatya Harsono $^{1} \cdot$ Aubrey Druce Wibawa $^{1} \cdot$ Putu Suardana $^{1}$. \\ Yoanes Maria Vianney (D) ${ }^{1} \cdot$ Sulistyo Emantoko Dwi Putra (D) $^{1}$
}

Received: 21 October 2019 / Accepted: 3 March 2020

(c) Springer Science+Business Media, LLC, part of Springer Nature 2020

\begin{abstract}
Diabetes is one of the most common metabolic diseases. Aside from the genetic factor, previous studies stated that other factors such as environment, lifestyle, and paternal-maternal condition play critical roles in diabetes through DNA methylation in specific areas of the genome. One of diabetic cases is caused by insulin resistance and changing the homeostasis of blood glucose control so glucose concentration stood beyond normal rate (hyperglycemia). High fat diet has been frequently studied and linked to triggering diabetes. However, most Asians consume rice (or food with high carbohydrate) and food with monosodium glutamate (MSG). This habit could lead to pathophysiology of type 2 diabetes mellitus (T2D). Previous studies showed that high-carbohydrate or high-MSG diet could change gene expression or modify protein activity in body metabolism. This imbalanced metabolism can lead to pleiotropic effects of diabetes mellitus. In this study, the authors have attempted to relate various changes in genes expression or protein activity to the high-carbohydrate and high-MSG-induced diabetes. The authors have also tried to relate several genes that contribute to pathophysiology of T2D and proposed several ideas of genes as markers and target for curing people with T2D. These are done by investigating altered activities of various genes that cause or are caused by diabetes. These genes are selected based on their roles in pathophysiology of T2D.
\end{abstract}

Keywords High carbohydrate $\cdot$ Insulin resistance $\cdot$ Monosodium glutamate $\cdot$ Obesity $\cdot$ Type 2 diabetes mellitus

$\begin{array}{ll}\text { Abbreviations } \\ \text { GLUT4 } & \text { Glucose transporter } 4 \\ \text { PDX1 } & \text { Pancreatic and duodenal homeobox } 1 \\ \text { NKX6.1 } & \text { NK6 homeobox 1 } \\ \text { MAFA } & \text { MAF bZIPtranscritpion factor A } \\ \text { FOXO1 } & \text { Forkhead box protein O1 } \\ \text { GRP-78 } & \text { Binding immunoglobulin protein } \\ \text { PERK } & \text { Protein kinase R (PKR)-like endoplasmic } \\ & \text { reticulum kinase } \\ \text { IRE1 } \alpha & \text { Inositol-requiring enzyme } 1 \alpha \\ \text { XBP1 } & \text { X-box binding protein 1 } \\ \text { CHOP } & \text { C/EBP homologous protein } \\ \text { INSIG1 } & \text { Insulin induced gene } 1\end{array}$

Sulistyo Emantoko Dwi Putra

emantoko@staff.ubaya.ac.id

1 Department of Biology, Faculty of Biotechnology, University of Surabaya, Raya Kalirungkut, Surabaya, East Java 60292, Indonesia
SREBP-1c Sterol regulatory element binding protein 1c

SIRT1 NAD-dependent deacetylase sirtuin-1

SCD1 Stearoyl-CoA desaturase-1

PPAR Peroxisome proliferator-activated receptor

ATF4 Activating transcription factor 4

CREB-2 cAMP-response element binding protein 2

MEG3 Maternally expressed 3

SLC2A4 Solute carrier family 2 member 4

H3K9me3 Trimethylation of lysine 9 on histone $\mathrm{H} 3$ protein

PCK1 Phosphoenolpyruvate carboxykinase 1 (soluble)

ACO Acyl-CoA oxidase

CPT1 Carnitine palmitoyltransferase 1

BIFEZ Bifunctionalenzyme

ANGPTL4 Angiopoietin-like 4

PDK4 Pyruvate dehydrogenase lipoamide kinase isozyme 4

TIF2 Transcriptional mediators/intermediary factor 2

UCP3 Mitochondrial uncoupling protein 3 
PGC-1 $\alpha$ Peroxisome proliferator-activated receptor gamma co-activator 1-alpha

SRC 1 Steroid Receptor Co-activator 1

aP2 Adipocyte Protein 2

SHP Small Heterodimer Partner

MSG Monosodium Glutamate

\section{Introduction}

Diabetic prevalences are continuously increasing and they were predicted to reach 693 million in 2045 [1]. Various factors contributed to the emergence of diabetes ranging from parental genetics [2], maternal epigenetic inheritance due to nutritional imbalances consumption during pregnancy [3], lifestyle, and diet [4, 5]. Physiologically, diabetes could be due to insulin resistance [6], insulin secretory dysfunction [7], or death of pancreas $\beta$-cell [8]. The pathogenesis of type 2 diabetes mellitus (T2D) related to obesity has been well reviewed [6]. Epidemic and epigenetics that convey relationship between genetics and environment are closely related to T2D cases [9, 10]. The fact that famines impact on the family health, pregnancy planning, lifestyle, and diet in early stages of pregnancy contributed to future risks of various metabolic disorders, such as obesity and diabetes. This fact has been wellreviewed in the literature [9]. Various environmental factors previously mentioned lead to various epigenetic modifications and cause early insulin resistance associated with the fetal low birth weight [10].

Certain patterns of diets increase the chances of T2D due to alteration in the gene expression. High-fat diet is the most commonly studied and frequently used to induce diabetes $[11,12]$. High-fat diets internalize and reduce the expression of pancreatic glucose transporter gene (GLUT2) and glucokinase caused by the hyperglycemia and create a vicious loop of impaired insulin secretion [13, 14]. This diet also reduces the expression of GLUT4 protein and causes insulin resistance in skeletal muscles. High-fat diets also inactivated insulin receptor substrate (IRS-1) in liver and caused inflammation in mice models [15]. Methylation studies on PDK4 also revealed that high-fat-diet-induced methylation on a specific $\mathrm{CpG}$ site before the onset of hyperglycemia as one proof of epigenetic regulation plays an important role in metabolic disorder [16].

Primary food with high glycemic index, such as rice, is a staple food for more than half of the world's population in various Asian countries [17]. High carbohydrate diet, such as refined grain is also associated with an increased risk of T2D [18-20]. High sucrose and fructose diets are also contributing factors to T2D since sucrose and fructose cause pancreas and liver toxicity [21-23]. Another relevant Asian food additive that can induce T2D is the high intake of
MSG [24-28]. Epigenetically, a newborn female in the suckling period who eats a high-carbohydrate diet has been reported to readily develop hyperinsulinemia and to acquire obesity in the adulthood [29]. The second generation of these female rats spontaneously develop the similar phenotype even without any intervention studies indicating maternal fetal programming [29]. MSG-induced obesity by subcutaneous injection of female Wistar rats' parent, has been reported to bring forth male offspring that experienced various metabolic disorders, such as insulin and leptin resistance [30]. These initial facts implied that both highcarbohydrate and high-MSG diets contribute to the emergence of T2D.

To the extent of the authors' literature reviews, diets with high carbohydrate and high MSG have not been so extensively reviewed as those with high fat (especially in the consequences of high-carbohydrate and high-MSG intakes on gene expression). This review focuses on exploring the genetic interactions of both diet patterns that leads to T2D. Literature reviews related to T2D and human central metabolism were employed to initially screen some genes or proteins that have been extensively studied. Then, the possibilities of alteration of these genetic expressions using carbohydrate and MSG adjustment were also investigated. Thus, this review can provide insights into the screening processes of genes that can serve as potential biomarkers in $\mathrm{T} 2 \mathrm{D}$ prediction. The genes or the proteins can also offer possible breakthroughs in therapies for T2D patients.

\section{Genetic aspects that promote T2D: high- carbohydrate diet study}

High-carbohydrate feeding after a period of time of noncarbohydrate diets caused the mice to enter fast hyperglycemic period [13]. The high-carbohydrate diet in mice models dephosphorylate FoxO1 without reducing its expression where the phosphorylation was regulated in Akt pathway. Thus, FoxO1 stayed in the nucleus and significantly reduced the expression of PDX1, NKX6.1, and $M A F A$ genes that are essential for the survival and the maintenance of $\beta$-pancreas cell and insulin production $[13,31,32]$. High-fructose diets were also found to increase both the m-RNA content of FoxOl and the expression of pancreatic GRP-78, PERK, IRE1 $\alpha, X B P 1, C H O P$ gene, hepatic $G R P-78$, and caspase activity [21]. All these genes belong to the family of endoplasmic reticulum stress markers and relate to cell death. Interestingly, high fructose diets also reduce the expression of INSIGI [21]. This is the protein that regulates $S R E B P-1 c$ that is important to synthesize fat when the cells are rich in carbohydrate [33]. In contrast, activation and retainment of FoxO1 in the nucleus by deacetylation are essential to protect $\beta$-pancreas 
cell of diabetic mice within the long term by reducing the dependence on fatty acid oxidation as energy source [34]. This signifies that FoxOl activation might be one approach of our body to control homeostasis.

Animal models showed that high-carbohydrate diet induced the expression of hepatic acetyl-CoA carboxylase stearoyl-CoA desaturase 1 gene $(S c d 1)$, while $S c d 1$ normally is not expressed in liver but expressed constitutively in adipose tissue [35-38]. High-carbohydrate diet was found to increase the expression of various elongase and desaturase enzymes that synthesize unsaturated fatty acid, especially monounsaturated fatty acid in liver [39]. Scdl activation created vicious cycle which created insulin resistance. Downregulation of $S c d l$ proved to increase the phosphorylation of AKT and to alleviate the insulin resistance [40-43].

Although Scdl might be an interesting gene to be downregulated, Scdl deficiency alone was found to be insufficient to protect mice from getting obese [44]. In contrast, the activation of $S c d l$ gene specifically in skeletal muscle enhanced the activation of PPAR- $\delta$ to oxidize fat and increased the metabolism in skeletal muscles that could protect T2D mice from obesity [45]. This opposing phenotype in skeletal muscles and hepatic cells both arising from the activation of $S c d l$ expression denoted that each protein behaves differently and possibly targets different proteins in each organ. The $S c d l$ gene correlation with high-carbohydrate diet has been investigated for more than two decades but with no firm consequences. Care must be taken when making a research to silence this gene or to make an inhibitor for Scd1. Clearly, more data are needed to be able to map the effect of $S c d l$ on not only various genes but also various organs.

ATF4 (or CREB2) deficiency has been shown to suppress the expression of $S C D 1$ in liver, and ATF4-deficiency mice has lower fat content compared with the normal genotype. In high-carbohydrate diet mice, deletion of ATF4 improved insulin sensitivity and caused hypoglycemia [46, 47]. ATF4 deletion also significantly reduced the expression of hepatic PPAR- $\gamma$ which contributed to lipogenesis resulting in reduction of other genes expression involved in lipogenesis, such as SREBP-1C and acetyl-coA carboxylase. ATF4 deletion also protected high-fructose diet mice from developing hypertriglyceridemia and liver steatosis [48]. This fact was further enhanced by the downregulation of ATF4 in liver by miRNA-214 that could alleviate gluconeogenesis and reduce the expression of FoxOl in high-fat diet mice [49]. MEG3, a noncoding RNA, was found to be a competing endogenous RNA for miRNA-214 that resulted in increase of ATF4 and FoxOl expressions that create insulin resistance [50]. These facts might seem that downregulating ATF4 or regulating the miRNA-214-MEG3 axis can be a promising way to combat $\mathrm{T} 2 \mathrm{D}$. Nevertheless, referring to the contrasting long-term effect of FoxO1 [34], more data are required to observe long-term effects of ATF4 up- or downregulation on the diabetic animal models.

Evenly, nutritional factors of high-carbohydrate and high-fat diet-induced diabetic mice overlap with each other in the genetic pathways when a different metabolic pathway is used. This condition possibly occurs when food enters the body and several mechanisms of metabolisms interact with each other to form a complex mechanism to maintain homeostasis. Prolonged imbalanced diet or excessive carbohydrate consumption may lead to pathophysiology of T2D. The idea of some gene expression and protein activity alterations when the body encounters high-carbohydrate diet is summarized in the following Figs. 1 and 2.

\section{Genetic aspects that promote T2D: high- MSG intervention study}

Monosodium glutamate (MSG) has been linked with various metabolic disorders. Metabolism of MSG by dietary intake is well reviewed [51]. Glutamate is a nonessential amino acid that is usually oxidized or acted as precursor for other amino acids in gut. With excess of MSG intakes, the intestine capacity to absorb MSG remain unchanged. In neonatal primate, high dose of MSG administered by gastric tube, induced elevation of glutamate, and aspartate content (the result of glutamate metabolism by liver) after 1 or $2 \mathrm{~h}$ of treatment without any lesion in neuron [52]. Thus, MSG is considered as GRAS food additive.

Here, the focus of the study is the genetical and experimental effects of MSG intervention study toward expression of genes and metabolism. However, it should be taken into account that various experimental data used MSG injection to develop obesity and hyperglycemic animal models to reveal the genetic architecture between MSG and T2D. MSG is also now a suspected obesogen - a small chemical that could disrupt fat metabolism and appetite [53]. MSG was found to impair glucagon-like peptide (GLP-1) secretion in cell model, a peptide hormone that is important for $\beta$-cell growth, and insulin production [54]. In short term $(3 \mathrm{~h})$, secretion of GLP-1 was increased, but in chronic term (72 h), cytotoxicity was observed and there was a reduction in GLP-1 secretion [55].

MSG-induced hyperglycemia caused the same insulin resistance phenomenon induced by streptozotocin. MSG also caused obesity in the nongenetic mice models. However, MSG-induced diabetic mice did not experience an increase in expression of TNF- $\alpha$, a marker that is usually used to indicate obesity and might also cause diabetes $[56,57]$. No reduction of pancreatic $\beta$-cell in the MSGinduced diabetes was observed compared with that in the streptozotocin-induced diabetes [25]. 

carbohydrate and high-fructose diets affecting gene expression and protein activity
Fig. 1 Mechanism of high-

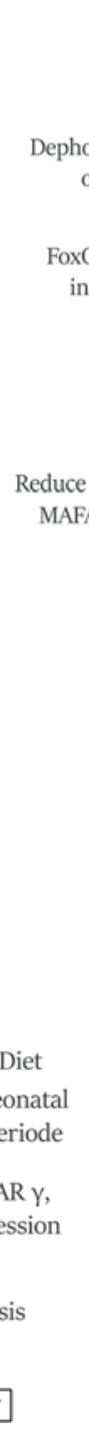

Fig. 2 Changes of gene expression by MSG-induced diabetes in neonatal period

MSG-induced diabetic mice exerted decreased content of GLUT4 protein (not GLUT1), disrupt glucose utilization, and caused insulin resistance [58]. This is due to methylation of Slc2a4 promoter area that produced GLUT4 by H3K9me3 using gastrocnemius skeletal cell [59]. An increase of Slc2a2 gene expression (encoding GLUT2) and $p c k 1$ (encoding key enzyme in gluconeogenesis in the liver) was also induced in MSG-diabetic mice. This increase caused glucose outflow and created hyperglycemia [60].

MSG-induced diabetes also takes a longer time to develop hyperglycemia phenomenon, and the obesity period is usually the first indicator [26, 61-63]. Subcutaneous injection of rats with MSG reduced the expression of genes related to the fat oxidation, such as PPAR $\alpha$, ACO, CPT1, and BIFEZ [64, 65]. Conversely, MSG-induced diabetic mice in neonatal period gain an increase of expression in PPAR $\alpha$ and PPAR $\gamma$, and inflammation [66]. Although both mechanisms are intertwined, MSG observably induced the lipogenesis. Chiglitazar, the agonist PPAR $\alpha$ and PPAR $\gamma$, is reported to inhibit the phosphorylation of PPAR $\gamma$, thus deactivates the protein and increases the expression of ANGPTL4 and PDK4 [67-69]. ANGPTL4 is a protein that protects human from getting obese and myocardial infarction due to high-fat diet by inhibiting the lipoprotein lipase activity, reducing free fatty acid levels in serum [70]. PDK4 is an enzyme that turns off the pyruvate dehydrogenase and in turn, activates the $\beta$-oxidation pathway that is often expressed in skeletal muscle cell, and can be repressed by insulin. An increase of PDK4 expression is often observed in diabetic patients and increases insulin resistance and dependence on fatty acids oxidation as energy source $[71,72]$. However, in a short-term high-fat diet, the increase of $P D K 4$ expression is important to balance the glucose and fat level. The increase of ANGPTLA and PDK4 expression is regarded as the feedback mechanism to protect cells from fatty acid-induced oxidative stress [73, 74].

The loss-of-function experiment using skeletal muscle cells and adipocytes on TIF2 revealed PPAR $\gamma$ expression reduction [75]. The deletion of TIF2 reduced the expression of lipoprotein lipase, aP2, and increased lipolysis and the resistance of MSG-diabetic induced mice from getting obese in combination with SRCl expression for better energy expenditure [75]. Experiment on $T I F 2^{-1-}$ mouse supported the idea about the role of TIF2 on obesity whereas TIF2 and SRC1 act antagonistically toward UCP3 expression [76]. Silencing TIF2 gene increased the expression of UCP3 and in turn, increased body 
metabolism, and reduced weight gain [77]. Loss-of-function of TIF 2 also induced the expression of PGC- $1 \alpha$ in skeletal muscle cells, and the expression increased the oxidative metabolism of muscle cell [76, 78]. SRC3 deletion on mice also increased the PGC- $1 \alpha$ activity by reducing acetylation on skeletal muscle cells [79]. However, expressed PGC-1 $\alpha$ raised different phenotypes from different organs and periods of induction. Pancreatic overexpression of PGC- $1 \alpha$ in neonatal period inhibited the expression of $P D X 1$. The inhibition of $P D X 1$ expression caused dysfunction and mass reduction in pancreatic $\beta$-cell. However, PGC- $1 \alpha$ overexpression in the adult mice did not affect the pancreatic $\beta$-cell [80].

Recently, SIRT1, a histone deacetylase protein, has been proved to increase insulin sensitivity. SIRT1 expression improved glycemic control and insulin sensitivity on liver, muscle, adipose tissue, and $\beta$-cell pancreas $[81,82]$. It is further supported by mice that are deficient in SIRT1 which develop hyperglycemic and insulin resistance [83]. MSG-induced diabetic mice does not seem to cause any changes in SIRTI expression level. However, various ligands that acted as SIRT1 activator such as resveratrol, SRT1720, and MHY2233, improved the steatosis condition [60,84, 85]. In contrast, genetic diabetic $d b / d b$ mice reportedly were in use [86]. Although the activation of SIRT1 did stimulate the pancreatic $\beta$-cell plasma insulin concentration, SIRT1 activation caused a reduction in body temperature and metabolism (torpor condition) with more long-term effects of weight gain and hepatic steatosis [86].

However, acute knockout of SIRT1 lead to reduction of hyperglycemia setting and an increase of insulin sensitivity by increasing the liver responsiveness to insulin and reducing gluconeogenesis [87, 88]. The results regarding SIRT1 effects on gluconeogenesis and insulin sensitivity seem inconsistent. This discrepancy could be due to the feedback mechanism on the SIRT1-FOXO1 pathway by SHP (encoded by NrOb2) [89]. Furthermore, SIRT1 knockout in healthy mice brings normal fed and fasting blood glucose level [89]. However, SIRT1 knockout in genetic diabetic mice (double knockout on IRS1/2) resulted in better blood glucose level and glucose tolerance, although the mice were still insulin resistant. This implied that SIRT1 activation can be completed in genetically derived diabetic patients or in already diabetic patients. SIRT1 treatment might not be used to prevent people from diabetes.

In general, MSG-induced mice are more related to obese phenomenon. Quite a few involved genes are intertwined with obesity, such as fat metabolism from PPARs family. While high-carbohydrate-induced diabetes can also cause lipogenesis by balancing the excess of carbohydrate into fat, MSG-induced diabetes seems to directly activate lipogenesis.
The changes in genes expression triggered by MSG- induced T2D are summarized in Fig. 3.

\section{Involvement of genes and proteins in T2D}

It is important to figure out whether the disruption of the gene expression is the reason for the $\mathrm{T} 2 \mathrm{D}$, or whether the disruption is generated by the T2D. Two categories were used to sort some genes whether the genes induce T2D, or T2D changes the genes expression (Table 1). The genes that could affect T2D development might be used as diabetes markers and targeted to prevent T2D. While some gene expressions that are altered after T2D has occurred can be treated to alleviate the diabetes symptoms. The delicate interaction of the proteins, such as pleiotropic effects and highly branched signaling pathways and feedback mechanisms, also complicates the treatment of the targeted gene without disrupting the homeostasis of our body. Genes or proteins whose activities are altered after diabetes and increase diabetes severity, or the further missing link that still has to be developed is placed in not determined (ND).

Various genes such as FOXO1, PDX1, ATF4, and INSIG1 proved to be important for the development of $\beta$-pancreas cells, or to maintain the balance of metabolism to increase glucose tolerance. Meanwhile, genes expression alteration that directly corelate with carbohydrate or fat metabolism, such as GLUT families, pckl, scdl, and PPAR are more likely caused by feedback mechanism and complex regulation to give better glucose level performa [60, 97]. Disturbance of expression in genes like ACO, CPT1, TIF2, $S R C 1, s c d 1$, and UCP3 in muscle cells and adipocyte cells are more into causing obesity, in which these genes are related to fat metabolism and energy expenditure. Caution must be taken that diabetes could also abberated these genes expression directly related to metabolism and disruption of these genes in early stage of development could also cause various physiological imbalances. However, genes like TIF2, $S R C 1$, and $P G C-1 \alpha$ were predicted to be more upstream in the signaling pathway. Thus, modulation of these genes might prevent further physiological abberations related to metabolism imbalances such as obesity and diabetes. SIRT1 expression was not changed by diabetes and its knockout also did not cause T2D. SIRT1 is a promising gene to be targeted in the already diabetic patient as previously stated above. We further hypothesized that based on the animal studies, both high carbohydrate (found in high glycemic index food or energy-dense food) and introduction of high MSG (by injection) might reinforce each other to increase the prevalence of T2D or other metabolic disorders. The possibility of intervention study employing both factors might be noteworthy to be investigated. 
Fig. 3 Mechanisms of changing genes expression affected by MSG-induced diabetes and of genes affecting MSG-induced diabetes

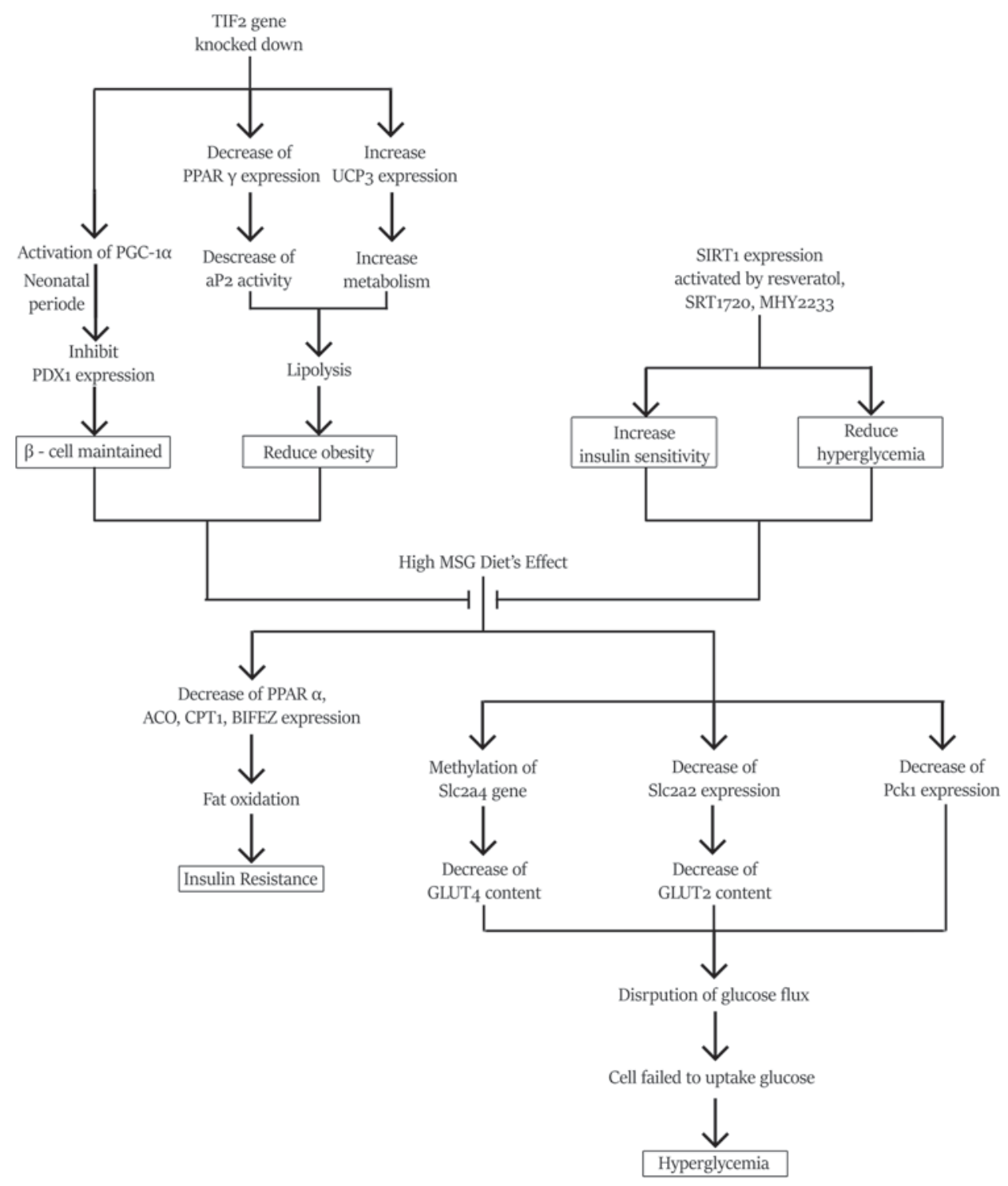

\section{Population-based studies of high- carbohydrate and high-MSG diet}

Using animal and cell line models, high-MSG and highcarbohydrate diets correlated and might also contribute to the onset of T2D by disrupting expression and the activity of various genes mentioned in Table 1 . However, studies on epidemiology might support or contrast the idea of the correlation between T2D and high-MSG or highcarbohydrate diet. Various factors contributed to this conditions such as age, ethnicity, genetics, anatomical and metabolic differences, or socioeconomics or even in the experimental design itself [100].

Population study of dietary carbohydrate intake above normal level in Japanese population showed that obese participants develops $\mathrm{T} 2 \mathrm{D}$ more readily than nonobese participants. This indicated that large samples, genetic effects, participants' backgrounds should be considered in the epidemiology study [101]. However, epidemiological studies in China, India, United States, and UAE supported the dietary style of high-carbohydrate intake (such as refined grain and added sugar) positively correlated with T2D [18, 102-105]. Another profound study on epidemiology related to the increasing risk of T2D was conducted on sugar-sweetened diet beverages in female US nurses in 1989 [106]. The intake of these high-calorie beverages (such as, soft drink and fruit punch) was said to be associated with the increasing chances of T2D development. More than $60 \%$ diabetic people live in China and India, followed by Japan [103, 107]. Asian countries, such as China, India, or UAE are predicted to yield a higher rate of diabetic prevalence [18, 102-105]. Although general 
Table 1 Summary of genes involved in diet-induced diabetes

\begin{tabular}{|c|c|c|c|c|c|c|}
\hline \multirow[t]{2}{*}{ Diet } & \multirow[t]{2}{*}{ Gene/protein } & \multirow[t]{2}{*}{ Effect } & \multicolumn{3}{|l|}{ Condition } & \multirow[t]{2}{*}{ Reference } \\
\hline & & & Changed by T2D & $\begin{array}{l}\text { Affecting T2D } \\
\text { development }\end{array}$ & ND & \\
\hline \multirow[t]{5}{*}{ High carbohydrate } & FoxO1 [protein] & Dephosphorylated & & $\checkmark$ & & [13] \\
\hline & Scdl [gene] & Increase of expression & & & $\checkmark$ & [36] \\
\hline & ATF4 [gene] & Increase of expression & & $\checkmark$ & & [48] \\
\hline & INSIG1 [gene] & Reduction of expression & & $\checkmark$ & & {$[90]$} \\
\hline & FoxO1 [gene] & Increase of expression & & $\checkmark$ & & {$[90]$} \\
\hline \multirow[t]{23}{*}{ High-MSG } & GLUT4 [protein] & $\begin{array}{l}\text { Reduction of expression accompanied with whole- } \\
\text { body insulin resistance and increased plasma } \\
\text { concentration of inflammatory markers }\end{array}$ & & & $\checkmark$ & {$[91]$} \\
\hline & slc2a4 [gene] & $\begin{array}{l}\text { Reduction of expression that contributes to the } \\
\text { impairment of glycemic homeostasis }\end{array}$ & & & $\checkmark$ & {$[92]$} \\
\hline & Slc $2 a 2$ [gene] & $\begin{array}{l}\text { Increase of the content and collaboration with } \\
\text { nonalcoholic steatohepatitis to facilitate the glucose } \\
\text { input to hepatocyte }\end{array}$ & & & $\checkmark$ & {$[93]$} \\
\hline & pck1 [gene] & Increase of expression level & & & $\checkmark$ & {$[94,95]$} \\
\hline & $\begin{array}{l}\operatorname{PPAR} \alpha \text { and } \\
\operatorname{PPAR} \gamma[\text { protein] }\end{array}$ & $\begin{array}{l}\text { Increase of the level and creation of inflammatory } \\
\text { effect(s) }\end{array}$ & & & $\checkmark$ & {$[66]$} \\
\hline & ACO [protein] & Lowered expression might cause obesity & & & $\checkmark$ & [96] \\
\hline & $C P T 1$ [gene] & $\begin{array}{l}\text { Increase of expression level possibly leading to } \\
\text { obesity }\end{array}$ & & & $\checkmark$ & {$[97]$} \\
\hline & $P D K 4$ [gene] & Increase of muscle PDK4 expression & & & $\checkmark$ & {$[98]$} \\
\hline & TIF2 [gene] & Deletion of this gene protects mice from obese & & & $\checkmark$ & {$[75]$} \\
\hline & $S R C 1$ [gene] & Antagonist of $T I F 2^{-}$ & & & $\checkmark$ & {$[76]$} \\
\hline & $P G C-1 \alpha$ & $\begin{array}{l}\text { Activation at neonatal period reduced } P D X 1 \\
\text { expression and pancreas maturation }\end{array}$ & & & $\checkmark$ & [99] \\
\hline & SIRT1 [gene] & $\begin{array}{l}\text { Increase of this gene expression alleviates symptoms } \\
\text { in the already diabetic patient }\end{array}$ & & & $\checkmark$ & [81] \\
\hline & slc2a4 [gene] & $\begin{array}{l}\text { Reduction of expression that contributes to the } \\
\text { impairment of glycemic homeostasis }\end{array}$ & & & $\checkmark$ & {$[92]$} \\
\hline & Slc2a2 [gene] & $\begin{array}{l}\text { Increase of the content and collaboration with } \\
\text { nonalcoholic steatohepatitis to facilitate the glucose } \\
\text { input to hepatocyte }\end{array}$ & & & $\checkmark$ & [93] \\
\hline & pck1 [gene] & Increase of expression level & & & $\checkmark$ & {$[94,95]$} \\
\hline & $\begin{array}{l}\operatorname{PPAR} \alpha \text { and } \\
\operatorname{PPAR} \gamma[\text { protein] }\end{array}$ & $\begin{array}{l}\text { Increase of the level and creation of inflammatory } \\
\text { effect(s) }\end{array}$ & & & $\checkmark$ & {$[66]$} \\
\hline & ACO [protein] & Lowered expression might cause obesity & & & $\checkmark$ & {$[96]$} \\
\hline & $C P T 1$ [gene] & $\begin{array}{l}\text { Increase of expression level possibly leading to } \\
\text { obesity }\end{array}$ & & & $\checkmark$ & {$[97]$} \\
\hline & PDK4 [gene] & Increase of muscle PDK4 expression & & & $\checkmark$ & [98] \\
\hline & $T I F 2$ [gene] & $\begin{array}{l}\text { Deletion of this gene protects mice from } \\
\text { getting obese }\end{array}$ & & & $\checkmark$ & {$[75]$} \\
\hline & $S R C 1$ [gene] & Antagonist of $T I F 2^{-}$ & & & $\checkmark$ & [76] \\
\hline & $P G C-1 \alpha$ & $\begin{array}{l}\text { Activation at neonatal period reduces } P D X 1 \\
\text { expression and pancreas maturation }\end{array}$ & & & $\checkmark$ & [99] \\
\hline & SIRT1 [gene] & $\begin{array}{l}\text { Increase of this gene expression alleviates symptoms } \\
\text { in the already diabetic patient }\end{array}$ & & & $\checkmark$ & [81] \\
\hline
\end{tabular}

population in Japan consume white rice and MSG-enriched food like people in other Asian countries, uniquely, Japan is projected to have only a small increase in the ratio of its diabetic people in 2025. This fact might be due to the nationwide health guidance and lifestyle intervention program [107-109]. 
While studies on epidemiology related to highcarbohydrate diet related to the risk of T2D development are clearly [18, 102-105], findings about human population study at risk of high-MSG diet are inconsistent. Studies on MSG-related diabetic cases have been frequently reported using animal models. There is a lack of epidemiological data of MSG consumption which contribute to T2D in comparison to those of high-carbohydrate consumption. Epidemiology in Spanish population has been linked to the increasing risks of getting T2D to cardiovascular diseases due to high glutamate plasma level [110]. Based on another epidemiology in Thailand, daily consumption exceeding $5 \mathrm{~g}$ of MSG is considered risky to carry metabolic disorders, including T2D [111]. MSG intakes have also been reported to increase the incidence of overweight [112]. However, two studies from the Jiangsu Nutrition Study argued that MSG intake did not correlate with obesity, and even high MSG intake was negatively associated with hyperglycemia [113, 114].

One possible explanation that could explain the opposing results among the studies of epidemiology is the unready transportation from the intestine into the blood circulation in contrast to various experimental data that used MSGinduced diabetic mice models by MSG subcutaneous injection [51, 115]. Another explanation arises from experimental data where life period is an important factor related to the genetic programming by environmental factors. Mice at the age of 4 months old with high-MSG diet are prone to various metabolic disorders, including the increased signs of glucose intolerance. However, along with the aging process, the impairment of metabolism from the obesity effects can be attenuated [116].

By considering both experimental data from animal or cell culture studies with epidemiological data, we summarize that high-carbohydrate diet evidently positively correlates with T2D and could cause the onset of T2D. Although MSG studies are still in conflict with one another, we do not encourage people to slacken their diets by consuming high amount of MSG based on the experimental data of MSG potentials to alter homeostasis on carbohydrate and fat metabolism. All in all, lifestyle intervention shows to be a promising primary prevention of diabetes, and healthy lifestyle is shown to be comparable with metformin intake as reported by Indian Diabetes Prevention Program [104]. Govermental policies can play a huge role on combating the increasing prevalence of diabetes by encouraging a healthy diet and lifestyle, such as taxation program in Thailand for beverages which contain high level of sugar content [117].

\section{Conclusion and future perspectives}

High-fat diet is commonly known to induce T2D, especially in the case of high-carbohydrate and high-MSG diets. However, high-MSG diet requires longer time to develop hyperglycemia preceded by obesity. Various genes, especially genes related to glucose and fat metabolism are interrelated within these two diets. Branched signal transduction pathways and different phenotypes of each gene in different organs or ages revealed complicated mechanisms that should be taken as precautions as the targeted gene of interest to treat T2D or to construct a specific biomarker for T2D. Initially, some activated or repressed genes are only a feedback mechanism to control body homeostasis related to the imbalanced diet. For example, high-carbohydrate diet increased SCD-1 expression. Prolonged feedback mechanism often creates vicious cycle thus developing metabolic syndromes including obesity and T2D.

Increasing FoxOl and ATF4 expressions or their activation in high-carbohydrate-induced diabetic mice will lead to insulin resistance. It could be interesting to study the repression or the side effects of both genes of diabetic mice for long-term experiments. Both genes might have potential uses as a biomarker for early detection of the T2D. The fact of MSG-induced diabetic mice often leads to the increase of gene expressions related to lipogenesis, such as PPARs family. However, the changes in PPARs expression and activation may disrupt the balance between glucose and lipid metabolism. Both TIF2 and SIRT1 are promising genes in alleviating insulin resistance developed from MSGinduced diabetes. However, these strategies have also exhibited some drawbacks. TIF2 silencing increased the expression of PGC- $1 \alpha$ that inhibited the maturation of pancreas at neonatal period. Further information on TIF2 silencing of pancreatic cells from various ages of mice models may enlighten the benefits of targeting TIF 2 as a gene of interest to treating T2D. It is still unclear how the MSG affects the TIF2 expression in $\beta$-cells. Similarly, SIRT1 is indeed an interesting target gene, however, precautions should be taken in drug administration, diet lifestyle, and targeted organs. Otherwise, the disruption of the delicate balance of homeostasis may lead to worsening physical conditions. Studying the SIRT1 signal transduction pathway and its effects on T2D in a more long-term experiment will shed more understanding into how SIRT1 maintains homeostasis.

Acknowledgements The research and writing of this paper was funded by Indonesia Ministry of Research, Technology, and Higher Education (021/SP-Lit/LPPM-01/DRPM/Multi/FTB/III/2019). We thank Helen Hendaria Kamandhari, Ph.D. for her editing and comments.

\section{Compliance with ethical standards}

Conflict of interest The authors declare that they have no conflict of interest. 
Ethical approval The studies conducted in this article do not involve human participants or animals.

Publisher's note Springer Nature remains neutral with regard to jurisdictional claims in published maps and institutional affiliations.

\section{References}

1. N. Cho, J.E. Shaw, S. Karuranga, Y. Huang, J.D. da Rocha Fernandes, A.W. Ohlrogge, B. Malanda, IDF Diabetes Atlas: Global estimates of diabetes prevalence for 2017 and projections for 2045. Diabetes Res. Clin. Pract. 138, 271-281 (2018)

2. S.K. Das, S.C. Elbein, The genetic basis of type 2 diabetes. Cellscience 2(4), 100-131 (2006)

3. J.C. Jimenez-Chillaron, M. Ramon-Krauel, S. Ribo, R. Diaz, Transgenerational epigenetic inheritance of diabetes risk as a consequence of early nutritional imbalances. Proc. Nutr. Soc. 75 (1), 78-89 (2015)

4. A. Alkhatib, C. Tsang, A. Tiss, T. Bahorun, H. Arefanian, R. Barake, Abdelkrim Khadir, J. danTuomilehto, Functional foods and lifestyle approaches for diabetes prevention and management. Nutrients 9(12), 1310 (2017)

5. Y. Sun, W. You, F. Almeida, P. Estabrooks, B. Davy, The effectiveness and cost of lifestyle interventions including nutrition education for diabetes prevention: a systematic review and meta-analysis. J. Acad. Nutr. Diet. 117(3), 404-421.e36 (2017)

6. S.E. Kahn, R.L. Hull, K.M. Utzschneider, Mechanisms linking obesity to insulin resistance and type 2 diabetes. Nature $\mathbf{4 4 4}$ (7121), 840 (2006)

7. C. Weyer, C. Bogardus, D.M. Mott, R.E. Pratley, The natural history of insulin secretory dysfunction and insulin resistance in the pathogenesis of type 2 diabetes mellitus. J. Clin. Investig. 104(6), 787-794 (1999)

8. M.Y. Donath, J.A. Ehses, K. Maedler, D.M. Schumann, H. Ellingsgaard, E. Eppler, M. Reinecke, Mechanisms of $\beta$-cell death in type 2 diabetes. Diabetes 54(Suppl 2), S108-S113 (2005)

9. P. Zimmet, Z. Shi, A. El-Osta, L. Ji, Epidemic T2DM, early development and epigenetics: implications of the Chinese Famine. Nat. Rev. Endocrinol. 14(12), 738-746 (2018)

10. M. Tian, C. Reichetzeder, J. Li, B. Hocher, Low birth weight, a risk factor for diseases in later life, is a surrogate of insulin resistance at birth. J. Hypertens. 37(11), 2123-2134 (2019)

11. E.R. Gilbert, Z. Fu, D. Liu, Development of a nongenetic mouse model of type 2 diabetes. Exp. Diabetes Res. 2011, 416254 (2011)

12. M. Manco, M. Calvani, G. Mingrone, Effects of dietary fatty acids on insulin sensitivity and secretion. Diabetes Obes. Metab. 6(6), 402-413 (2004)

13. O. Kluth, F. Mirhashemi, S. Scherneck, D. Kaiser, R. Kluge, S. Neschen, H.G. Joost, A. Schürmann, Dissociation of lipotoxicity and glucotoxicity in a mouse model of obesity associated diabetes: role of forkhead box O1 (FOXO1) in glucose-induced beta cell failure. Diabetologia 54(3), 605-616 (2011)

14. Y.B. Kim, S. Iwashita, T. Tamura, K. Tokuyama, M. Suzuki, Effect of high-fat diet on the gene expression of pancreatic GLUT2 and glucokinase in rats. Biochem. Biophys. Res. Commun. 208(3), 1092-1098 (1995)

15. Z. Liu, I.Y. Patil, T. Jiang, H. Sancheti, J.P. Walsh, B.L. Stiles, F. Yin, E. Cadenas, High-fat diet induces hepatic insulin resistance and impairment of synaptic plasticity. PloS ONE 10(5), e0128274 (2015)

16. S.E.D. Putra, S. Singajaya, F. Thesman, D.A. Pranoto, R. Sanjaya, Y.M. Vianney, I.B.M. Artadana, Aberrant PDK4 promoter methylation preceding hyperglycemia in a mouse model. Appl. Biochem. Biotechnol. (2019). https://doi.org/10.1007/s12010019-03143-6

17. S. Muthayya, J.D. Sugimoto, S. Montgomery, G.F. Maberly, An overview of global rice production, supply, trade, and consumption. Ann. N. Y. Acad. Sci. 1324(1), 7-14 (2014)

18. Y. Li, D.D. Wang, S.H. Ley, M. Vasanti, A.G. Howard, Y. He, F.B. Hu, Time trends of dietary and lifestyle factors and their potential impact on diabetes burden in China. Diabetes Care 40 (12), 1685-1694 (2017)

19. E.A. Hu, A. Pan, V. Malik, Q. Sun, White rice consumption and risk of type 2 diabetes: meta-analysis and systematic review. BMJ 344, e1454 (2012)

20. V. Mohan, G. Radhika, P. Vijayalakshmi, V. Sudha, Can the diabetes/cardiovascular disease epidemic in India be explained, at least in part, by excess refined grain (rice) intake? Indian J. Med. Res. 131, 369-372 (2010)

21. M. Balakumar, L. Raji, D. Prabhu, C. Sathishkumar, P. Prabu, V. Mohan, M. Balasubramanyam, High-fructose diet is as detrimental as high-fat diet in the induction of insulin resistance and diabetes mediated by hepatic/pancreatic endoplasmic reticulum (ER) stress. Mol. Cell. Biochem. 423(1-2), 93-104 (2016)

22. M.E. Bizeau, M.J. Pagliassotti, Hepatic adaptations to sucrose and fructose. Metabolism 54(9), 1189-1201 (2005)

23. M. Dirlewanger, P. Schneiter, E. Jéquier, L. Tappy, Effects of fructose on hepatic glucose metabolism in humans. Am. J. Physiol. Endocrinol. Metab. 279(4), E907-E911 (2000)

24. Y. Sasaki, W. Suzuki, T. Shimada, S. Iizuka, S. Nakamura, M. Nagata, M. Fujimoto, K. Tsuneyama, R. Hokao, K. Miyamoto, M. Aburada, Dose dependent development of diabetes mellitus and non-alcoholic steatohepatitis in monosodium glutamateinduced obese mice. Life Sci. 85(13-14), 490-498 (2009)

25. J.F. Morrison, S. Shehab, R. Sheen, S. Dhanasekaran, M. Shaffiullah, E. Mensah-Brown, Sensory and autonomic nerve changes in the monosodium glutamate-treated rat: a model of type II diabetes. Exp. Physiol. 93(2), 213-222 (2008)

26. M. Nagata, W. Suzuki, S. Iizuka, M. Tabuchi, H. Maruyama, S. Takeda, M. Aburada, K.I. Miyamoto, Type 2 diabetes mellitus in obese mouse model induced by monosodium glutamate. Exp. Anim. 55(2), 109-115 (2006)

27. K. Beyreuther, H.K. Biesalski, J.D. Fernstrom, P. Grimm, W.P. Hammes, U. Heinemann, O. Kempski, P. Stehle, H. Steinhart, R. Walker, Consensus meeting: monosodium glutamate-an update. Eur. J. Clin. Nutr. 61(3), 304-313 (2007)

28. W. Prawirohardjono, I. Dwiprahasto, I. Astuti, S. Hadiwandowo, E. Kristin, M. Muhammad, M.F. Kelly, The administration to Indonesians of monosodium L-glutamate in Indonesian foods: an assessment of adverse reactions in a randomized double-blind, crossover, placebo-controlled study. J. Nutr. 130(4), 1074S-1076S (2000)

29. M. Srinivasan, R. Aalinkeel, F. Song, M.S. Patel, Programming of islet functions in the progeny of hyperinsulinemic/obese rats. Diabetes 52(4), 984-990 (2003)

30. R.A. Miranda, C.C. da Silva Franco, J.C. de Oliveira, L.F. Barella, L.P. Tófolo, T.A. Ribeiro, P.C. Lisboa, Cross-fostering reduces obesity induced by early exposure to monosodium glutamate in male rats. Endocrine 55(1), 101-112 (2017)

31. T. Kitamura, J. Nakae, Y. Kitamura, Y. Kido, W.H. Biggs, C.V. Wright, M.F. White, K.C. Arden, D. Accili, The forkhead transcription factor Foxo1 links insulin signaling to $\mathrm{Pdx} 1$ regulation of pancreatic $\beta$ cell growth. J. Clin. Investig. 110(12), 1839-1847 (2002)

32. U. Ahlgren, J. Jonsson, L. Jonsson, K. Simu, H. Edlund, $\beta$-Cellspecific inactivation of the mouseIpf1/Pdx 1 gene results in loss of the $\beta$-cell phenotype and maturity onset diabetes. Genes Dev. 12(12), 1763-1768 (1998) 
33. G. Sethi, M.K. Shanmugam, A.P. Kumar, SREBP-1c as a molecular bridge between lipogenesis and cell cycle progression of clear cell renal carcinoma. Biosci. Rep. 37(6), BSR20171270 (2017)

34. J.Y. Kim-Muller, Y.J.R. Kim, J. Fan, S. Zhao, A.S. Banks, M. Prentki, D. Accili, FoxO1 deacetylation decreases fatty acid oxidation in $\beta$-cells and sustains insulin secretion in diabetes. $J$. Biol. Chem. 291(19), 10162-10172 (2016)

35. J.M. Ntambi, Dietary regulation of stearoyl-CoA desaturase 1 gene expression in mouse liver. J. Biol. Chem. 267(15), 10925-10930 (1992)

36. K.M. Waters, J.M. Ntambi, Insulin and dietary fructose induce stearoyl-CoA desaturase 1 gene expression of diabetic mice. J. Biol. Chem. 269(44), 27773-27777 (1994)

37. J.M. Ntambi, The regulation of stearoyl-CoA desaturase (SCD). Prog. Lipid Res. 34(2), 139-150 (1995)

38. M.E. Pape, F. Lopez-Casillas, K.H. Kim, Physiological regulation of acetyl-CoA carboxylase gene expression: effects of diet, diabetes, and lactation on acetyl-CoA carboxylase mRNA. Arch. Biochem. Biophys. 267(1), 104-109 (1988)

39. M.P. Rogowski, M.T. Flowers, A.D. Stamatikos, J.M. Ntambi, C.M. Paton, SCD1 activity in muscle increases triglyceride PUFA content, exercise capacity, and PPAR $\delta$ expression in mice. J. Lipid Res. 54(10), 2636-2646 (2013)

40. J. Drąg, A. Goździalska, M. Knapik-Czajka, A. Gawędzka, K. Gawlik, J. Jaśkiewicz, Effect of high carbohydrate diet on elongase and desaturase activity and accompanying gene expression in rat's liver. Genes Nutr. 12(1), 1-8 (2017)

41. M. Miyazaki, M.T. Flowers, H. Sampath, K. Chu, C. Otzelberger, X. Liu, J.M. Ntambi, Hepatic stearoyl-CoA desaturase-1 deficiency protects mice from carbohydrate-induced adiposity and hepatic steatosis. Cell Metab. 6(6), 484-496 (2007)

42. R. Gutiérrez-Juárez, A. Pocai, C. Mulas, H. Ono, S. Bhanot, B.P. Monia, L. Rossetti, Critical role of stearoyl-CoA desaturase-1 (SCD1) in the onset of diet-induced hepatic insulin resistance. J. Clin. Investig. 116, 1686-1695 (2006)

43. G. Jiang, Z. Li, F. Liu, K. Ellsworth, Q. Dallas-Yang, M. Wu, R. Bergeron, Prevention of obesity in mice by antisense oligonucleotide inhibitors of stearoyl-CoA desaturase-1. J. Clin. Investig. 115(4), 1030-1038 (2005)

44. J.M. Ntambi, M. Miyazaki, J.P. Stoehr, H. Lan, C.M. Kendziorski, B.S. Yandell, Y. Song, P. Cohen, J.M. Friedman, A.D. Attie, Loss of stearoyl-CoA desaturase-1 function protects mice against adiposity. Proc. Natl Acad. Sci. 99(17), 11482-11486 (2002)

45. M.T. Flowers, L. Ade, M.S. Strable, J.M. Ntambi, Combined deletion of SCD1 from adipose tissue and liver does not protect mice from obesity. J. Lipid Res. 53(8), 1646-1653 (2012)

46. H. Li, Q. Meng, F. Xiao, S. Chen, Y. Du, J. Yu, C. Wang, F. Guo, ATF4 deficiency protects mice from high-carbohydratediet-inducced liver steatosis. Biochem. J. 438(2), 283-289 (2011)

47. J. Seo, E.S. Fortuno, J.M. Suh, D. Stenesen, W. Tang, E.J. Parks, C.M. Adams, T. Townes, J.M. Graff, Atf4 regulates obesity, glucose homeostasis, and energy expenditure. Diabetes 58(11), 2565-2573 (2009)

48. G. Xiao, T. Zhang, S. Yu, S. Lee, V. Calabuig-Navarro, J. Yamauchi, S. Ringquist, H.H. Dong, ATF4 protein deficiency protects against high fructose-induced hypertriglyceridemia in mice. J. Biol. Chem. 288(35), 25350-25361 (2013)

49. K. Li, J. Zhang, J. Yu, B. Liu, Y. Guo, J. Deng, S. Chen, S. Wang, F. Guo, MicroRNA-214 suppresses gluconeogenesis by targeting activating transcriptional factor 4. J. Biol. Chem. 290 (13), 8185-8195 (2015)

50. X. Zhu, H. Li, Y. Wu, J. Zhou, G. Yang, W. Wang, lncRNA MEG3 promotes hepatic insulin resistance by serving as a competing endogenous RNA of miR-214 to regulate ATF4 expression. Int. J. Mol. Med. 43(1), 345-357 (2019)

51. D.G. Burrin, B. Stoll, Metabolic fate and function of dietary glutamate in the gut. Am. J. Clin. Nutr. 90(3), 850S-856S (2009)

52. L.D. Stegink, W.A. Reynolds, L.J. Filer Jr, R.M. Pitkin, D.P. Boaz, M.C. Brummel, Monosodium glutamate metabolism in the neonatal monkey. Am. J. Physiol. 229(1), 246-250 (1975)

53. M. Shannon, J. Wilson, Y. Xie, L. Connolly, In vitro bioassay investigations of suspected obesogen monosodium glutamate at the level of nuclear receptor binding and steroidogenesis. Toxicol. Lett. 301, 11-16 (2019)

54. L.L. Kjems, J.J. Holst, A. Vølund, S. Madsbad, The influence of GLP-1 on glucose-stimulated insulin secretion: effects on $\beta$-cell sensitivity in type 2 and nondiabetic subjects. Diabetes 52(2), 380-386 (2003)

55. M. Shannon, B. Green, G. Willars, J. Wilson, N. Matthews, J. Lamb, A. Gillespie, L. Connolly, The endocrine disrupting potential of monosodium glutamate (MSG) on secretion of the glucagon-like peptide-1 (GLP-1) gut hormone and GLP-1 receptor interaction. Toxicol. Lett. 265, 97-105 (2017)

56. G.S. Hotamisligil, B.M. Spiegelman, Tumor necrosis factor $\alpha$ : a key component of the obesity-diabetes link. Diabetes 43(11), 1271-1278 (1994)

57. G.S. Hotamisligil, N.S. Shargill, B.M. Spiegelman, Adipose expression of tumor necrosis factor-alpha: direct role in obesitylinked insulin resistance. Science 259(5091), 87-91 (1993)

58. U.F. Machado, Y. Shimizu, M. Saito, Decreased glucose transporter (GLUT 4) content in insulin-sensitive tissues of obese aurothioglucose-and monosodium glutamate-treated mice. Horm. Metab. Res. 25(09), 462-465 (1993)

59. C.Y. Yonamine, A.B. Alves-Wagner, J.V. Esteves, M.M. Okamoto, M.L. Correa-Giannella, D. Giannella-Neto, U.F. Machado, Diabetes induces tri-methylation at lysine 9 of histone 3 at Slc2a4 gene in skeletal muscle: A new target to improve glycemic control. Mol. Cell. Endocrinol. 481, 26-34 (2019)

60. C. Yonamine, E. Pinheiro-Machado, M. Michalani, A. AlvesWagner, J. Esteves, H. Freitas, U. Machado, Resveratrol improves glycemic control in type 2 diabetic obese mice by regulating glucose transporter expression in skeletal muscle and liver. Molecules 22(7), 1180 (2017)

61. S. vio Brandelero Jr, M.L. ciaBonfleur, R.A. Ribeiro, E.C. Vanzela, C.A. Nassar, P.O. Nassar, S.L. Balbo, Decreased TNFa gene expression in periodontal ligature in MSG-obese rats: A possible protective effect of hypothalamic obesity against periodontal disease?. Arch. Oral. Biol. 57(3), 300-306 (2011)

62. M.S. Islam, T. du Loots, Experimental rodent models of type 2 diabetes: a review. Methods Find. Exp. Clin. Pharmacol. 31(4), 249-261 (2009)

63. A.E. Hirata, I.S.D. Andrade, P. Vaskevicius, M.S. Dolnikoff, Monosodium glutamate (MSG)-obese rats develop glucose intolerance and insulin resistance to peripheral glucose uptake. Braz. J. Med. Biol. Res. 30, 671-67 (1997)

64. S.N. Liu, Q. Liu, L.Y. Li, Y. Huan, S.J. Sun, Z.F. Shen, Longterm fenofibrate treatment impaired glucose-stimulated insulin secretion and up-regulated pancreatic NF-kappa B and iNOS expression in monosodium glutamate-induced obese rats: Is that a latent disadvantage? J. Transl. Med. 9(1), 176 (2011)

65. P.P. Li, S. Shan, Y.T. Chen, Z.Q. Ning, S.J. Sun, Q. Liu, X.P. Lu, M.Z. Xie, Z.F. Shen, The PPAR $\alpha / \gamma$ dual agonist chiglitazar improves insulin resistance and dyslipidemia in MSG obese rats. Br. J. Pharmacol. 148(5), 610-618 (2006)

66. R. Roman-Ramos, J.C. Almanza-Perez, R. Garcia-Macedo, G. Blancas-Flores, A. Fortis-Barrera, E.I. Jasso, M. GarciaLorenzana, A.E. Campos-Sepulveda, M. Cruz, F.J. AlarconAguilar, Monosodium glutamate neonatal intoxication associated 
with obesity in adult stage is characterized by chronic inflammation and increased mrna expression of peroxisome proliferator-activated receptors in mice. Basic Clin. Pharmacol. Toxicol. 108(6), 406-413 (2011)

67. D.S. Pan, W. Wang, N.S. Liu, Q.J. Yang, K. Zhang, J.Z. Zhu, S Shan, Z.B. Li, Z.Q. Ning, L. Huang, X.P. Lu, Chiglitazar preferentially regulates gene expression via configuration-restricted binding and phosphorylation inhibition of PPAR $\gamma$. PPAR Res. 2017, 4313561 (2017)

68. K.A. Burns, J.P.V. Heuvel, Modulation of PPAR activity via phosphorylation. Biochim. Biophys. Acta. 1771(8), 952-960 (2007)

69. E. Hu, J.B. Kim, P. Sarraf, B.M. Spiegelman, Inhibition of adipogenesis through MAP kinase-mediated phosphorylation of PPAR $\gamma$. Science 274(5295), 2100-2103 (1996)

70. M.J. Lafferty, K.C. Bradford, D.A. Erie, S.B. Neher, Angiopoietin-like protein 4 inhibition of lipoprotein lipase evidence for reversible complex formation. J. Biol. Chem. 288(40), 28524-28534 (2013)

71. S.D. van Otterdijk, A.M. Binder, K.S. vel Szic, J. Schwald, K.B. Michels, DNA methylation of candidate genes in peripheral blood from patients with type 2 diabetes or the metabolic syndrome. PloS ONE 12(7), e0180955 (2017)

72. A.J. McAinch, L.M. Cornall, R. Watts, D.H. Hryciw, P.E. O'Brien, D. Cameron-Smith, Increased pyruvate dehydrogenase kinase expression in cultured myotubes from obese and diabetic individuals. Eur. J. Nutr. 54(7), 1033-1043 (2015)

73. A. Georgiadi, L. Lichtenstein, T. Degenhardt, M. Boekschoten, M. van Bilsen, B. Desvergne, M. Müller, S. Kersten, Induction of cardiac Angptl4 by dietary fatty acids is mediated by peroxisome proliferator-activated receptor $\beta / \delta$ and protects against fatty acid-inducedoxidative stress. Circ. Res. 106(11), 1712-1721 (2009)

74. K. Chokkalingam, K. Jewell, L. Norton, J. Littlewood, L.J.C. Van Loon, P. Mansell, I.A. Macdonald, K. Tsintzas, High-fat/lowcarbohydrate diet reduces insulin-stimulated carbohydrate oxidation but stimulates nonoxidative glucose disposal in humans: an important role for skeletal muscle pyruvate dehydrogenase kinase 4. J. Clin. Endocrinol. Metab. 92(1), 284-292 (2007)

75. F. Picard, M. Géhin, J.S. Annicotte, S. Rocchi, M.F. Champy, B. W. O'Malley, P. Chambon, J. Auwerx, SRC-1 and TIF2 control energy balance between white and brown adipose tissues. Cell 111(7), 931-941 (2002)

76. D. Duteil, C. Chambon, F. Ali, R. Malivindi, J. Zoll, S. Kato, B. Geny, P. Chambon, D. Metzger, The transcriptional coregulators TIF2 and SRC-1 regulate energy homeostasis by modulating mitochondrial respiration in skeletal muscles. Cell Metab. 12(5), 496-508 (2010)

77. C. Tiraby, G. Tavernier, F. Capel, A. Mairal, F. Crampes, J. Rami, C. Pujol, J.A. Boutin, D. Langin, Resistance to high-fatdiet-induced obesity and sexual dimorphism in the metabolic responses of transgenic mice with moderate uncoupling protein 3 overexpression in glycolytic skeletal muscles. Diabetologia 50 (10), 2190-2199 (2007)

78. A. Besseiche, J.P. Riveline, J.F. Gautier, B. Breant, B. Blondeau, Metabolic roles of PGC- $1 \alpha$ and its implications for type 2 diabetes. Diabetes Metab. 41(5), 347-357 (2015)

79. A. Coste, J.F. Louet, M. Lagouge, C. Lerin, M.C. Antal, H. Meziane, K. Schoonjans, P. Puigserver, B.W. O’Malley, J. Auwerx, The genetic ablation of SRC-3 protects against obesity and improves insulin sensitivity by reducing the acetylation of PGC-1 $\alpha$. Proc. Natl Acad. Sci. 105(44), 17187-17192 (2008)

80. B. Valtat, J.P. Riveline, P. Zhang, A. Singh-Estivalet, M. Armanet, N. Venteclef, A. Besseiche, D.P. Kelly, F. Tronche, P. Ferré, J.F. Gautier, B. Bréant, J.F. Gautier, Fetal PGC- $1 \alpha$ overexpression programs adult pancreatic $\beta$-cell dysfunction. Diabetes 62(4), 1206-1216 (2013)
81. Y. Cao, X. Jiang, H. Ma, Y. Wang, P. Xue, Y. Liu, SIRT1 and insulin resistance. J. Diabetes Complic. 30(1), 178-183 (2016)

82. T. Yoshizaki, S. Schenk, T. Imamura, J.L. Babendure, N Sonoda, E.J. Bae, D.Y. Oh, M. Lu, J.C. Milne, C. Westphal, G. Bandyopadhyay, G. Bandyopadhyay, SIRT1 inhibits inflammatory pathways in macrophages and modulates insulin sensitivity. Am. J. Physiol. Endocrinol. Metab. 298(3), E419-E428 (2009)

83. R.H. Wang, H.S. Kim, C. Xiao, X. Xu, O. Gavrilova, C.X. Deng, Hepatic Sirt1 deficiency in mice impairs mTorc2/Akt signaling and results in hyperglycemia, oxidative damage, and insulin resistance. J. Clin. Investig. 121(11), 4477-4490 (2011)

84. M.J. Kim, H.J. An, D.H. Kim, B. Lee, H.J. Lee, S. Ullah, S.J. Kim, H.O. Jeong, K.M. Moon, E.K. Lee, J. Yang, J. Akter, P. Chun, H.R. Moon, J. Yang, Novel SIRT1 activator MHY2233 improves glucose tolerance and reduces hepatic lipid accumulation in db/db mice. Bioorg. Med. Chem. Lett. 28(4), 684-688 (2018)

85. Y. Yamazaki, I. Usui, Y. Kanatani, Y. Matsuya, K. Tsuneyama, S. Fujisaka, A. Bukhari, H. Suzuki, S. Senda, S. Imanishi, K. Hirata, M. Ishiki, R. Hayashi, M. Urakaze, H. Nemoto, M. Kobayashi, K. Hirata, Treatment with SRT1720, a SIRT1 activator, ameliorates fatty liver with reduced expression of lipogenic enzymes in MSG mice. Am. J. Physiol. Endocrinol. Metab. 297(5), E1179-E1186 (2009)

86. R.E. Gilbert, K. Thai, S.L. Advani, C.L. Cummins, D.M. Kepecs, S.A. Schroer, M. Woo, Y. Zhang, SIRT1 activation ameliorates hyperglycaemia by inducing a torpor-like state in an obese mouse model of type 2 diabetes. Diabetologia 58(4), 819-827 (2015)

87. D.M. Erion, S. Yonemitsu, Y. Nie, Y. Nagai, M.P. Gillum, J.J. Hsiao, T. Iwasaki, R. Stark, D. Weismann, X.X. Yu, S.F. Murray, S. Bhanot, B.P. Monia, T.L. Horvath, Q. Gao, V.T. Samuel, S.F. Murray, SIRT1 knockdown in liver decreases basal hepatic glucose production and increases hepatic insulin responsiveness in diabetic rats. Proc. Natl Acad. Sci. 106(27), 11288-11293 (2009)

88. J.T. Rodgers, P. Puigserver, Fasting-dependent glucose and lipid metabolic response through hepatic sirtuin 1. Proc. Natl Acad. Sci. 104(31), 12861-12866 (2007)

89. D. Wei, R. Tao, Y. Zhang, M.F. White, X.C. Dong, Feedback regulation of hepatic gluconeogenesis through modulation of SHP/Nr0b2 gene expression by Sirt1 and FoxO1. Am. J. Physiol. Endocrinol. Metab. 300(2), E312-E320 (2010)

90. N. Sud, H. Zhang, K. Pan, X. Cheng, J. Cui, Q. Su, Aberrant expression of microRNA induced by high-fructose diet: implications in the pathogenesis of hyperlipidemia and hepatic insulin resistance. J. Nutr. Biochem. 43, 125-131 (2017). https://doi.org/ 10.1016/j.jnutbio.2017.02.003

91. N.M. Leguisamo, A.M. Lehnen, U.F. Machado, M.M. Okamoto, M.M. Markoski, G.H. Pinto, B.D. Schaan, GLUT4 content decreases along with insulin resistance and high levels of inflammatory markers in rats with metabolic syndrome. Cardiovasc Diabetol. 11(1), 100 (2012)

92. A.C. Poletto, A. David-Silva, A.P. Yamamoto, M. de, U.F. Machado, D.T. Furuya, Reduced Slc2a4/GLUT4 expression in subcutaneous adipose tissue of monosodium glutamate obese mice is recovered after atorvastatin treatment. Diabetol. Metab. Syndr. 7(1), 18 (2015)

93. A.D. Silva, R.R. Favaro, D.T. Furuya, P.E. Silva, L.T. Belpiede, H.S. Freitas, M.M. Okamoto, F. Barrance, T.M. Zorn, U.F. Machado, Overexpression of GLUT2/ Slc2a2 are accompanied by Hnf- $1 \alpha$, Hnf- $4 \alpha$ and Hnf-3 $\beta$ transcriptional. J. Liver, 4(3) (2015)

94. K.S. Collison, M.Z. Zaidi, S.M. Saleh, N.J. Makhoul, A. Inglis, J. Burrows, J.A. Araujo, F.A. Al-Mohanna, Nutrigenomics of 
hepatic steatosis in a feline model: effect of monosodium glutamate, fructose, and trans-fat feeding. Genes Nutr. 7(2), 265-280 (2011)

95. E.G. Beale, R.E. Hammer, B. Antoine, C. Forest, Disregulatedglyceroneogenesis: PCK1 as a candidate diabetes and obesity gene. Trends Endocrinol. Metab. 15(3), 129-135 (2004)

96. K.S. Collison, Z. Maqbool, S.M. Saleh, A. Inglis, N.J. Makhoul, R. Bakheet, M. Al-Johi, R. Al-Rabiah, M.Z. Zaidi, F.A. AlMohanna, Effect of dietary monosodium glutamate ontransfatinduced nonalcoholic fatty liver disease. J. Lipid Res. 50(8), 1521-1537 (2008)

97. K.S. Collison, N.J. Makhoul, M.Z. Zaidi, A. Inglis, B.L. Andres, R. Ubungen, S. Saleh, F.A. Al-Mohanna, Prediabetic changes in gene expression induced by aspartame and monosodium glutamate in trans fat-fed C57Bl/6 J mice. Nutr. Metab. 10(1), 44 (2013)

98. K.S. Collison, Z.M. Maqbool, A.L. Inglis, N.J. Makhoul, S.M. Saleh, R.H. Bakheet, M.A. Al-Johi, R.K. Al-Rabiah, M.Z. Zaidi, F.A. Al-Mohanna, Effect of dietary monosodium glutamate on HFCS-induced hepatic steatosis: expression profiles in the liver and visceral fat. Obesity 18(6), 1122-1134 (2010)

99. H. Wu, X. Deng, Y. Shi, Y. Su, J. Wei, H. Duan, PGC- $1 \alpha$, glucose metabolism and type 2 diabetes mellitus. J. Endocrinol. 229(3), R99-R115 (2016)

100. Y. Zheng, S.H. Ley, F.B. Hu, Global aetiology and epidemiology of type 2 diabetes mellitus and its complications. Nat. Rev. Endocrinol. 14(2), 88 (2018)

101. M. Sakurai, K. Nakamura, K. Miura, T. Takamura, K. Yoshita, S.Y. Nagasawa, H. Nakagawa, Dietary carbohydrate intake, presence of obesity and the incident risk of type 2 diabetes in Japanese men. J. Diabetes Investig. 7(3), 343-351 (2016)

102. A. Khawaja, S. Qassim, N. Hassan, E.S.A. Arafa, Added sugar: nutritional knowledge and consumption pattern of a principal driver of obesity and diabetes among undergraduates in UAE. Diabetes Metab. Syndr. Clin. Res. Rev. 13(4), 2579-2584 (2019)

103. A. Nanditha, R.C. Ma, A. Ramachandran, C. Snehalatha, J.C. Chan, K.S. Chia, J.E. Shaw, P.Z. Zimmet, Diabetes in Asia and the Pacific: implications for the global epidemic. Diabetes Care 39(3), 472-485 (2016)

104. A. Ramachandran, C. Snehalatha, S. Mary, B. Mukesh, A.D. Bhaskar, V. Vijay, The Indian Diabetes Prevention Programme shows that lifestyle modification and metformin prevent type 2 diabetes in Asian Indian subjects with impaired glucose tolerance (IDPP-1). Diabetologia 49(2), 289-297 (2006)

105. L.S. Gross, L. Li, E.S. Ford, S. Liu, Increased consumption of refined carbohydrates and the epidemic of type 2 diabetes in the United States: an ecologic assessment. Am. J. Clin. Nutr. 79(5), 774-779 (2004)

106. M.B. Schulze, J.E. Manson, D.S. Ludwig, G.A. Colditz, M.J. Stampfer, W.C. Willett, F.B. Hu, Sugar-sweetened beverages, weight gain, and incidence of type 2 diabetes in young and middle-aged women. JAMA 292(8), 927-934 (2004)
107. J.C. Chan, V. Malik, W. Jia, T. Kadowaki, C.S. Yajnik, K.H. Yoon, F.B. Hu, Diabetes in Asia: epidemiology, risk factors, and pathophysiology. JAMA 301(20), 2129-2140 (2009)

108. K. Tsushita, A.S. Hosler, K. Miura, Y. Ito, T. Fukuda, A. Kitamura, K. Tatara, Rationale and descriptive analysis of specific health guidance: the nationwide lifestyle intervention program targeting metabolic syndrome in Japan. J. Atheroscler. Thromb 25(4), 308-322 (2018)

109. K. Kosaka, M. Noda, T. Kuzuya, Prevention of type 2 diabetes by lifestyle intervention: a Japanese trial in IGT males. Diabetes Res. Clin. Pract. 67(2), 152-162 (2005)

110. X. Liu, Y. Zheng, M. Guasch-Ferré, M. Ruiz-Canela, E. Toledo, C. Clish, L. Liang, C. Razquin, D. Corella, R. Estruch, M. Fito, E. Gómez-Gracia, F. Arós, E. Ros, J. Lapetra, M. Fiol, L. Serra-Majem, C. Papandreou, M.A. Martínez-González, F.B. Hu, J. Salas-Salvadó, High plasma glutamate and low glutamine-to-glutamate ratio are associated with type 2 diabetes: case-cohort study within the PREDIMED trial. Nutr. Metab. Cardiovasc. Dis. 29(10), 1040-1049 (2019)

111. T. Insawang, C. Selmi, U. Cha'on, S. Pethlert, P. Yongvanit, P. Areejitranusorn, P. Boonsiri, T. Khampitak, R. Tangrassameeprasert, C. Pinitsoontorn, V. Prasongwattana, M.E. Gershwin, V. Prasongwattana, Monosodium glutamate (MSG) intake is associated with the prevalence of metabolic syndrome in a rural Thai population. Nutr. Metab. 9(1), 50 (2012)

112. K. He, S. Du, P. Xun, S. Sharma, H. Wang, F. Zhai, B. Popkin, Consumption of monosodium glutamate in relation to incidence of overweight in Chinese adults: China Health and Nutrition Survey (CHNS). Am. J. Clin. Nutr. 93(6), 1328-1336 (2011)

113. Z. Shi, N.D. Luscombe-Marsh, G.A. Wittert, B. Yuan, Y. Dai, X. Pan, A.W. Taylor, Monosodium glutamate is not associated with obesity or a greater prevalence of weight gain over 5 years: findings from the Jiangsu Nutrition Study of Chinese adults. Br. J. Nutr. 104(3), 457-463 (2010)

114. Z. Shi, A.W. Taylor, B. Yuan, H. Zuo, G.A. Wittert, Monosodium glutamate intake is inversely related to the risk of hyperglycemia. Clin. Nutr. 33(5), 823-828 (2014)

115. J.T. Brosnan, A. Drewnowski, M.I. Friedman, Is there a relationship between dietary MSG obesity in animals or humans? Amino Acids 46(9), 2075-2087 (2014)

116. R. Hernández-Bautista, F. Alarcón-Aguilar, D.C. EscobarVillanueva, J. Almanza-Pérez, H. Merino-Aguilar, M. Fainstein, N. López-Diazguerrero, Biochemical alterations during the obese-aging process in female and male monosodium glutamate (MSG)-treated mice. Int. J. Mol. Sci. 15(7), 11473-11494 (2014)

117. V. Chavasit, W. Kriengsinyos, J. Photi, K. Tontisirin, Trends of increases in potential risk factors and prevalence rates of diabetes mellitus in Thailand. Eur. J. Clin. Nutr. 71(7), 839 (2017) 


\section{Emantoko_High_Carbohydrate.p df \\ by Sulistyo Harsono}

Submission date: 01-Feb-2021 05:20PM (UTC+0700)

Submission ID: 1498970295

File name: Emantoko_High_Carbohydrate.pdf (838.69K)

Word count: 9445

Character count: 51382 


\title{
The genetic basis of high-carbohydrate and high-monosodium glutamate diet related to the increase of likelihood of type 2 diabetes mellitus: a review
}

\author{
Joshua Nathanael' ${ }^{1}$ Hans Cristian Adhinatya Harsono ${ }^{1} \cdot$ Aubrey Druce Wibawa' ${ }^{1}$ Putu Suardana' \\ Yoanes Maria Vianney $\odot^{1} \cdot$ Sulistyo Emantoko Dwi Putra $\odot^{1}$ \\ Received: 21 October 2019 / Accepted: 3 March 2020 \\ O Springer Science+Business Media, LLC, part of Springer Nature 2020
}

\section{Abstract}

Diabetes is one of the most common metabolic diseases. Aside from the genetic factor, previous studies stated that other factors such as environment, lifestyle, and paternal-maternal condition play critical roles in diabetes through DNA methylation in specific areas of the genome. One of diabetic cases is caused by insulin resistance and changing the homeostasis of blood glucose control so glucose concentration stood beyond normal rate (hyperglycemia). High fat diet has been frequently studied and linked to triggering diabetes. However, most Asians consume rice ( ${ }_{29}$ jood with high carbohydrate) and food with monosodium glutamate (MSG). This habit could lead to pathophysiology of type 2 diabetes mellitus (T2D). Previous studies showed that high-carbohydrate or high-MSG diet could change gene expression or modify protein activity in body metabolism. This imbalanc 7 metabolism can lead to pleiotropic effects of diabetes mellitus. In this study, the authors have attempted to relate various changes in genes expression or protein activity to the high-carbohydrate and high-MSG-induced diabetes. The authors have also tried to relate several genes that contribute to pathophysiology of $\mathrm{T} 2 \mathrm{D}$ and proposed several ideas of genes as markers and target for curing people with T2D. These are done by investigating altered activities of various genes that cause or are caused by diabetes. These genes are selected based on their roles in pathophysiology of T2D.

Keywords High carbohydrate $\cdot$ Insulin resistance $\cdot$ Monosodium glutamate $\cdot$ Obesity $\cdot$ Type 2 diabetes mellitus

Abbreviations
$\begin{array}{ll}\text { GLUT4 } & \text { 9lucose transporter } 4 \\ \text { PDX1 } & \text { Pancreatic and duodenal homeobox } 1 \\ \text { NKX6.1 } & \text { NK6 homeobox 1 } \\ \text { MAFA } & \text { MAF bZIPtranscritpion factor A } \\ \text { FOXO1 } & \text { Forkhead box protein O1 } \\ \text { GRP-78 } & \text { 3inding immunoglobulin protein } \\ \text { PERK } & \begin{array}{l}\text { Protein kinase R (PKR)-like endoplasmic } \\ \text { reticulum kinase }\end{array} \\ \text { IRE1 } \alpha & \text { Inositol-requiring enzyme 1 } \alpha \\ \text { XBP1 } & \text { X-box binding protein 1 } \\ \text { CHOP } & \text { C/EBP homologous protein } \\ \text { INSIG1 } & \text { Insulin induced gene 1 }\end{array}$

$\checkmark$ Sulistyo Emantoko Dwi Putra emantoko@staff.ubayaac.id

1 Department of Biology, Faculty of Biotechnology, University of Surabaya, Raya Kalirungkut, Surabaya, East Java 60292. Indonesia
4 SREBP-1c Sterol regulatory element binding protein

SIRT1 NAD-dependent deacetylase sirtuin-I

SCD1 Stearoyl-CoA desaturase-1

PPAR 15 oxisome proliferator-activated receptor

ATF4 Activating transcription factor 4

CREB-2 CAMP-response element binding protein 2

MEG3 38ternally expressed 3

SLC2A4 Solute carrier family 2 member 4

$\mathrm{H} 3 \mathrm{~K}$ 9me3 Trimethylation of lysine 9 on histone $\mathrm{H} 3$ protein

28 K1 Phosphoenolpyruvate carboxykinase 1 (soluble)

ACO Acyl-CoA oxidase

CPT1 Carnitine palmitoyltransferase 1

BIFEZ Bifunctionalenzyme

ANGPTL4 Angiopoietin-like 4

PDK4 Pyruvate dehydrogenase lipoamide kinase isozyme 4

TIF2 Transcriptional mediators/intermediary factor 2

UCP3 Mitochondrial uncoupling protein 3 
PGC-1 $\alpha$ Peroxisome proliferator-activated receptor gamma co-activator 1-alpha

SRC 1 Steroid Receptor Co-activator 1

aP2 Adipocyte Protein 2

SHP Small Heterodimer Partner

MSG Monosodium Glutamate

\section{Introduction}

Diabetic prevalences are continuously increasing and they were predicted to reach 693 million in 2045 [1]. Various factors contributed to the emergence of diabetes ranging from parental genetics [2], maternal epigenetic inheritance due to nutritional imbalances consumption during pregnancy [3], lifestyle, and diet [4, 5]. Physiologically, diabetes could be due to insulin resistance [6], insulin secretory dysfunction [7], 37 death of pancreas $\beta$-cell [8]. The pathogenesis of type 2 diabetes mellitus (T2D) related to obesity has been well reviewed [6]. Epidemic and epigenetics that convey relationship between genetics and environment are closely related to T2D cases $[9,10]$. The fact that famines impact on the family health, pregnancy planning, lifestyle, and diet in early stages of 22 nancy contributed to future risks of various metabolic disorders, such as obesity and diabetes. This fact has been wellreviewed in the literature [9]. Various environmental factors previously mentioned lead to various epigenetic modifications and cause early insulin resistance associated with the fetal low birth weight [10].

Certain patterns of diets increase the chances of T2D due to alteration in the gene expression. High-fat diet is the most commonly studied and frequently used to induce diabetes $[11,12]$. High-fat diets internalize and reduce the expression of pancreatic glucose transporter gene (GLUT2) and glucokinase caused by the hyperglycemia and create a vicious $l_{34}$ of impaired insulin secretion [13, 14]. This diet al reduces the expression of GLUT4 protein and causes 36 alin re 33 ance in skeletal muscles. High-fat diets also inactivated insulin receptor substrate (IRS-1) in liver and caused inflammation in mice models [15]. Methylation studies on PDK4 also revealed that high-fat-diet-induced methylation on a specific $\mathrm{CpG}$ site before the onset of hyperglycemia as one proof of epigenetic regulation plays an important role in metabolic disorder [16].

Primary food with high glycemic index, such as rice, is a staple food for more than half of the world's population in various Asian $\mathrm{c}_{27}$ tries [17]. High carbohydrate diet, such as refined grain is also associated with an increased risk of T2D [18-20]. High sucrose and fructose diets are also contributing factors to T2D since sucrose and fructose cause pancreas and liver toxicity [21-23]. Another relevant Asian food additive that can induce T2D is the high intake of
MSG [24-28]. Epigenetically, a newborn female in the suckling period who eats a high-carbohydrate diet has been reported to readily develop hyperinsulinemia and to acquire obesity in the adulthood [29]. The second generation of these female rats spontaneously develop the similar phenotype even without any intervention studies indicating maternal fetal programming [29]. MSG-induced obesity by subcutaneous injection of female Wistar rats' parent, has been reported to bring forth male offspring that experienced various metabolic disorders, such as insulin and leptin resistance [30]. These initial facts implied that both highcarbohydrate and high-MSG diets contribute to the emergence of T2D.

To the extent of the authors' literature reviews, diets with high carbohydrate and high MSG have not been so extensively reviewed as those with high fat (especially in the con 21 uences of high-carbohydrate and high-MSG intakes on gene expression). This review focuses on exploring the genetic interactions of both diet pattems that leads to T2D. Literature reviews related to $\mathrm{T} 2 \mathrm{D}$ and human central metabolism were employed to initially screen some genes or proteins that have been extensively studied. Then, the possibilities of alteration of these genetic expressions using carbohydrate and MSG adjustment were also investigated. Thus, this review can provide insights into the screening processes of genes that can serve as potential biomarkers in T2D prediction. The genes or the proteins can also offer possible breakthroughs in therapies for T2D patients.

\section{Genetic aspects that promote T2D: high- carbohydrate diet study}

High-carbohydrate feeding after a period of time of noncarbohydrate diets caused the mice to enter fast hyperglycemic period [13]. The high-carbohydrate diet in mice models dephosphorylate FoxO1 without reducing its expression where the phosphorylation was regulated in Akt pathway. $26^{11}$, FoxO1 stayed in the nucleus and significantly reduced the expression of $P D X I, N K X{ }_{8}$, and $M A F A$ genes that are essential for the survival and the maintenance of $\beta$-pancreas cell and insulin production $[13,31,32]$. High-fructose diets were also fou 32 o increase both the m-RNA content of FoxOl and the expression of pancreatic GRP-78, PERK, IREI, XBPI, CHOP gene, hepatic GRP-78, and caspase activity [21]. All these genes belong to the family of endoplasmic reticulum stress markers and relate to cell death. Interestingly, high fructose diets also reduce the expression of INSIG1 [21]. This is the protein that regulates SREBP-1C that is important to synthesize fat when the cells are rich in carbohydrate [33]. In contrast, activation and retainment of FoxOl in the nucleus by deacetylation are essential to protect $\beta$-pancreas 
cell of diabetic mice within the long term by reducing the dependence on fatty acid oxidation as energy source [34]. This signifies that $\mathrm{FoxOl}$ activation might be one approach of our body to control homeostasis. 20

Animal models showed that high-carbohydrate diet 19 uced the expression of hepatic acetyl-CoA carboxylase stearoyl-CoA desaturase 1 gene $(S c d I)$, while $S c d l$ normally is not expressed in liver but expressed constitutively in adipose tissue [35-38]. High-carbohydrate diet was found to increase the expression of various elongase and desaturase enzymes that synthesize unsaturated fatty acid, especially monounsaturated fatty acid in liver [39]. Scdl activation created vicious cycle which created insulin resistance. Downregulation of $S c d l$ proved to increase the phosphorylation of AKT and to alleviate the insulin resistance [40-43].

Although $S c d l$ might be an interesting gene to be downregulated, Scdl deficiency alone was found to insufficient to protect mice from getting obese [44]. In contrast, the activation of Scdl gene specifically in skeletal muscle enhanced the activation of PPAR- $\delta$ to oxidize fat and increased the metabolism in skeletal muscles that could protect T2D mice from obesity [45]. This opposing phenotype in skeletal muscles and hepatic cells both arising from the activation of $S c d l$ expression denoted that each protein behaves differently and possibly targets different proteins in each organ. The $S c d l$ gene correlation with high-carbohydrate diet has been investigated for more than two decades but with no firm consequences. Care must be taken when making a research to silence this gene or to make an inhibitor for Scd1. Clearly, more data are needed to be able to map the effect of $S c d l$ on not only various genes but also various organs.

ATF4 (or CREB2) deficiency has been shown to suppress the expression of $S C D 1$ in liver, and ATF4-deficiency mice has lower fat content compared with the normal genotype. In high-carbohydrate diet mice, deletion of ATF4 improved insulin sensitivity and caused hypoglycemia [46, 47]. ATF4 deletion also significantly reduced the expression of hepatic PPAR- $\gamma$ which contributed to lip 18 enesis resulting in reduction of other genes expression involved in lipogenesis, such as SREBP-IC and acetyl-coA carboxylase. ATF4 deletion also protected high-fructose diet mice from developing hypertriglyceridemia and liver steatosis [48]. This fact was further enhanced by the downregulation of ATF 4 in liver by miRNA-214 that could alleviate gluconeogenesis and reduce the expression of $\mathrm{FoxOl}$ in high-fat diet mice [49]. MEG3, a noncoding RNA, was found to be a competing endogenous RNA for miRNA-214 that resulted in increase of ATF4 and FoxOI expression 5 that create insulin resistance [50]. These facts might seem that downregulating ATF4 or regulating the miRNA-214-MEG3 axis can be a promising way to combat T2D. Nevertheless, referring to the contrasting long-term effect of FoxOl [34], more data are required to observe long-term effects of ATF4 up- or downregulation on the diabetic animal models.

Evenly, nutritional factors of high-carbohydrate and high-fat diet-induced diabetic mice overlap with each other in the genetic pathways when a different metabolic pathway is used. This condition possibly occurs when food enters the body and several mechanisms of metabolisms interact with each other to form a complex mechanism to maintain homeostasis. Prolonged imbalanced diet or excessive carbohydrate consumption may lead to pathophysiology of T2D. The idea of some gene expression and protein activity alterations when the body encounters high-carbohydrate diet is summarized in the following Figs. 1 and 2.

\section{Genetic aspects that promote T2D: high- MSG intervention study}

Monosodium glutamate (MSG) has been linked with various metabolic disorders. Metabolism of MSG by dietary intake is well reviewed [51]. Glutamate is a nonessential amino acid that is usually oxidized or acted as precursor for other amino acids in gut. With excess of MSG intakes, the intestine capacity to absorb MSG remain unchanged. In neonatal primate, high dose of MSG administered by gastric tube, induced elevation of glutamate, and aspartate content (the result of glutamate metabolism by liver) after $1 / 25 \mathrm{~h}$ of treatment without any lesion in neuron [52]. Thus, MSG is considered as GRAS food additive.

Here, the focus of the study is the genetical and experimental effects of MSG intervention study toward expression of genes and metabolism. However, it should be taken into account that various experimental data used MSG injection to develop obesity and hyperglycemic animal models to reveal the genetic architecture between MSG and T2D. MSG is also now a suspected obesogen - a small chemical that could disrupt fat metabolism and appetite [53]. MSG was found to impair 31 cagon-like peptide ${ }_{8}$ GLP-1) secretion in cell model, a peptide hormone that is important for $\beta$-cell growth, and insulin production [54]. In short term $(3 \mathrm{~h})$, secretion of GLP-1 was increased, but in c 35 nic term $(72 \mathrm{~h})$, cytotoxicity was observed and there was a reduction in GLP-1 secretion [55].

MSG-induced hyperglycemia caused the same insulin resistance phenomenon induced by streptozotocin. MSG also caused obesity in the nongenetic mice models. However, MSG-induced diabetic mice did not experience an increase in expression of TNF- $\alpha$, a marker that is usually used to indicate obesity and might also cause diabetes $[56,57]$. No reduction of pancreatic $\beta$-cell in the MSGinduced diabetes was observed compared with that in the streptozotocin-induced diabetes [25]. 
Fig. 1 Mechanism of highcarbohydrate and high-fructose diets affecting gene expression and protein activity

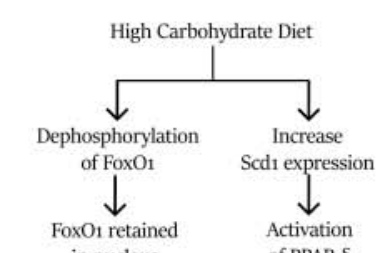

Activation
in nucleus

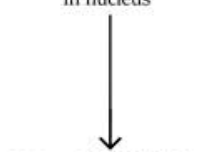

Reduce PDX1, NKX6.1, MAFA expression

(1)

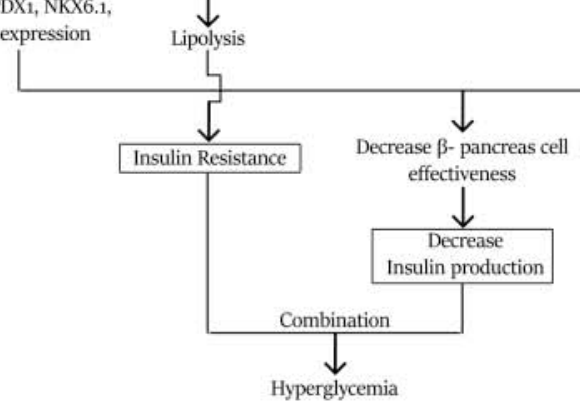

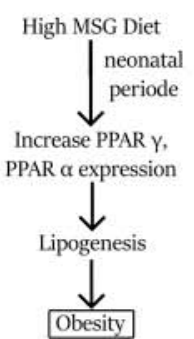

Fig. 2 Changes of gene expression by MSG-induced diabetes in neonatal period

MSG-induced diabetic mice exerted decreased content of GLUT4 protein (not GLUT1), disrupt glucose utilization, and caused insulin resistance [58]. This is due to methylation of Slc2a4 promoter area that produced GLUT4 by H3K9me3 using gastrocnemius skeletal cell [59]. An increase of $S l c 2 a 2$ gene expression (encoding GLUT2) and $p c k l$ (encoding key enzyme in gluconeogenesis in the liver) was also induced in MSG-diabetic mice. This increase caused glucose outflow and created hyperglycemia [60].

MSG-induced diabetes also takes a longer time to develop hyperglycemia phenomenon, and the obesity period is usually the first indicator $[26,6177$. Subcutaneous injection of rats with MSG reduced the expression of genes related to the fat oxidation, such as PPAR $\alpha$, ACO, CPT1, and BIFEZ [64, 65]. Conversely, MSG-induced diabetic mice in neonatal period gain an increase of expression in PPAR $\alpha$ and PPAR $\gamma$, and inflammation [66]. Although both mechanisms are intertwined, MSG observably induced the lipogenes ${ }_{24}$ Chiglitazar, the agonist PPAR $\alpha$ and PPAR $\gamma$, is reported to inhibit the phosphorylation of PPAR $\gamma$, thus deactivates the protein and increases the expression of ANGPTL4 and PDK4 [67-69]. ANGPTL4 is a protein that protects human from getting obese and myocardial infarction due to high-fat diet by inhibiting the lipoprotein lipase activity, reducing free fatty acid levels in serum [70]. PDK4 is an enzyme that turns off the pyruvate dehydrogenase and in turn, activates the $\beta$-oxidation pathway that is often expressed in skeletal muscle cell, and can be repressed by insulin. An increase of PDK4 expression is often observed in diabetic patients and increases insulin resistance and dependence on fatty pids oxidation as energy source $[71,72]$. However, in a short-term high-fat diet, the increase of $P D K 4$ expression is important to balance the glucose and fat level. The increase of ANGPTL4 an $P D K 4$ expression is regarded as the feedback mechanism to protect cells from fatty acid-induced oxidative stress [73, 74].

The loss-of-function experiment using skeletal muscle cells and adipocytes on TIF 2 revealed PPAR $\gamma$ expression reduction [75]. The deletion of $T I F 2$ reduced the expression of lipoprotein lipase, aP2, and increased lipolysis and the resistance of MSG-diabetic induced mice from getting obese in combination with $S R C l$ expression for better energy expenditure [75]. Experiment on $T I F 2^{-1-}$ mouse supported the idea about the role of TIF2 on obesity whereas $T I F 2$ and $S R C 1$ act antagonistically toward $U C P 3$ expression [76]. Silencing TIF2 gene increased the expression of UCP3 and in tum, increased body 
metabolism, and reduc 23 weight gain [77]. Loss-of-function of TIF2 also induced the expression of PGC- $1 \alpha$ in skeletal muscle cells, and the expression increased the oxidative metabolism of muscle cell [76, 78]. SRC3 deletion on mice also increased the PGC- $1 \alpha$ activity by reducing acetylation on skeletal muscle cells [79]. However, expressed PGC-1 $\alpha$ raised different phenotypes from different organs and periods of induction. Pancreatic overexpression of PGC-1 $\alpha$ in neonatal period inhibited the expression of PDXI. The inhibition of $P D X 1$ expression caused dysfunction and mass reduction in pancreatic $\beta$-cell. However, PGC- $1 \alpha$ overexpression in the adult mice did not affect the pancreatic $\beta$-cell [80].

Recently, SIRT1, a histone deacetylase protein, has been proved to increase insulin sensitivity. SIRTI expression improved glycemic control and insulin sensitivity on liver, muscle, adipose tissue, and $\beta$-cell pancreas $[81,82]$. It is further supported by mice that are deficient in SIRT1 which develop hyperglycemic and insulin resistance [83]. MSG-induced diabetic mice does not seem to cause any changes in SIRT1 expression level. However, various ligands that acted as SIRT1 activator such as resveratrol, SRT1720, and MHY2233, improved the steatosis condition $[60,84,85]$. In contrast, genetic diabetic $d b / d b$ mice reportedly were in use [86]. Although the activation of SIRT1 did stimulate the pancreatic $\beta$-cell plasma insulin concentration, SIRT1 activation caused a reduction in body temperature and metabolism (torpor condition) with more long-term effects of weight gain and hepatic steatosis [86].

However, acute knockout of SIRT1 lead to reduction of hyperglycemia setting and an increase of insulin sensitivity by increasing the liver responsiveness to insulin and reducing gluconeogenesis $[87,88]$. The results regarding SIRT1 effects on gluconeogenesis and insulin sensitivity seem inconsistent. This discrepancy could be due to the feedback mechanism on the SIRTI-FOXOI pathway by SHP (encoded by $\mathrm{NrOb2}$ ) [89]. Furthermore, SIRT1 knockout in healthy mice brings normal fed and fasting blood glucose level [89]. However, SIRT1 knockout in genetic diabetic mice (double knockout on IRS1/2) resulted in better blood glucose level and glucose tolerance, although the mice were still insulin resistant. This implied that SIRTI activation can be completed in genetically derived diabetic patients or in already diabetic patients. SIRTI treatment might not be used to prevent people from diabetes.

In general, MSG-induced mice are more related to obese phenomenon. Quite a few involved genes are intertwined with obesity, such as fat metabolism from PPARs family. While high-carbohydrate-induced diabetes can also cause lipogenesis by balancing the excess of carbohydrate into fat, MSG-induced diabetes seems to directly activate lipogenesis.
The changes in genes expression triggered by MSG- induced T2D are summarized in Fig. 3.

\section{Involvement of genes and proteins in T2D}

It is important to figure out whether the disruption of the gene expression is the reason for the $\mathrm{T} 2 \mathrm{D}$, or whether the disruption is generated by the T2D. Two categories were used to sort some genes whether the genes induce T2D, or T2D changes the genes expression (Table 1). The genes that could affect T2D development might be used as diabetes markers and targeted to prevent T2D. While some gene expressions that are altered after T2D has occurred can be treated to alleviate the diabetes symptoms. The delicate interaction of the proteins, such as pleiotropic effects and highly branched signaling pathways and feedback mechanisms, also complicates the treatment of the targeted gene without disrupting the homeostasis of our body. Genes or proteins whose activities are altered after diabetes and increase diabetes severity, or the further missing link that still has to be developed is placed in not determined (ND).

Various ger 8 such as FOXOI, PDXI, ATF4, and INSIGI proved to be important for the development of $\beta$-pancreas cells, or to maintain the balance of metabolism to increase glucose tolerance. Meanwhile, genes expression alteration that directly corelate with carbohydrate or fat metabolism, such as GLUT families, pckl, scdl, and PPAR are more likely caused by feedback mechanism and complex regulation to give better glucose level performa [60, 97]. Disturbance of expression in genes like ACO, CPTI, TIF2, $S R C 1, s c d 1$, and $U C P 3$ in muscle cells and adipocyte cells are more into causing obesity, in which these genes are related to fat metabolism and energy expenditure. Caution must be taken that diabetes could also abberated these genes expression directly related to metabolism and disruption of these genes in early stage of development could also cause various physiological imbalances. However, genes like $T I F 2$, $S R C 1$, and $P G C-1 \alpha$ were predicted to be more upstream in the signaling pathway. Thus, modulation of these genes might prevent further physiological abberations related to metabolism imbalances such as obesity and diabetes. SIRTI expression was not changed by diabetes and its knockout also did not cause T2D. SIRT1 is a promising gene to be targeted in the already diabetic patient as previously stated above. We further hypothesized that based on the animal studies, both high carbohydrate (found in high glycemic index food or energy-dense food) and introduction of high MSG (by injection) might reinforce each other to increase the prevalence of T2D or other metabolic disorders. The possibility of intervention study employing both factors might be noteworthy to be investigated. 
Fig. 3 Mechanisms of changing genes expression affected by MSG-induced diabetes and of genes affecting MSG-induced diabetes

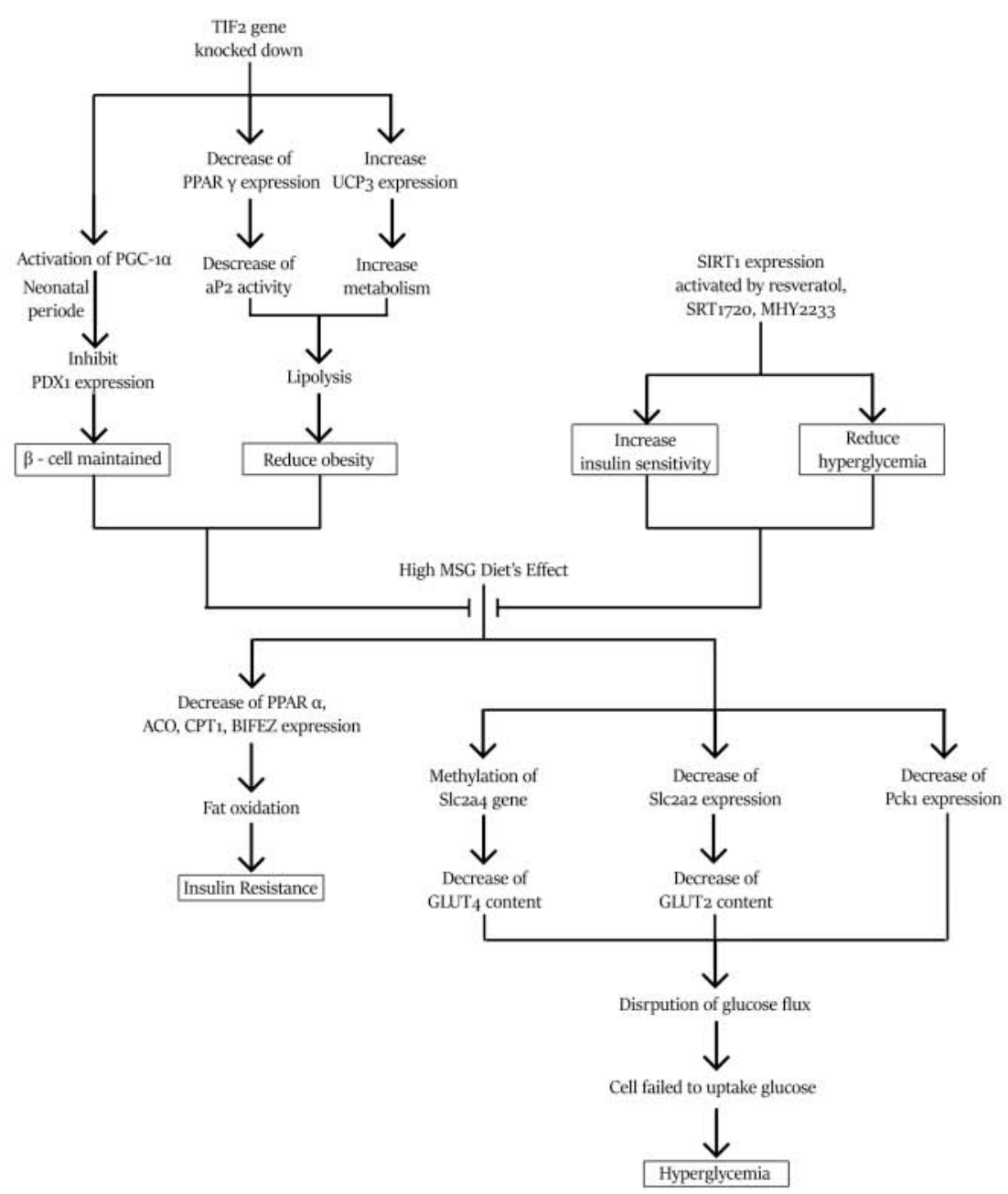

\section{Population-based studies of high- carbohydrate and high-MSG diet}

Using animal and cell line models, high-MSG and highcarbohydrate diets correlated and might also contribute to the onset of T2D by disrupting expression and the activity of various genes mentioned in Table 1. However, studies on epidemiology might support or contrast the idea of the correlation between T2D and high-MSG or highcarbohydrate diet. Various factors contributed to this conditions such as age, ethnicity, genetics, anatomical and metabolic differences, or socioeconomics or even in the experimental design itself [100].

Population study of dietary carbohydrate intake above normal level in Japanese population showed that obese participants develops T2D more readily than nonobese participants. This indicated that large samples, genetic effects, participants' backgrounds should be considered in the epidemiology study [101]. However, epidemiological studies in China, India, United States, and UAE supported the dietary style of high-carbohydrate intake (such as refined grain and added sugar) positively correlated with T2D [18, 102-105]. Another profound study on epidemiology related to the increasing risk of T2D was conducted on sugar-sweetened diet beverages in female US nurses in 1989 [106]. The intake of these high-calorie beverages (such as, soft drink and fruit punch) was said to be associated with the increasing chances of T2D development. More than $60 \%$ diabetic people live in China and India, followed by Japan [103, 107]. Asian countries, such as China, India, or UAE are predicted to yield a higher rate of diabetic prevalence [18, 102-105]. Although general 


\begin{tabular}{|c|c|c|c|c|c|c|}
\hline \multirow[t]{2}{*}{ Diet } & \multirow[t]{2}{*}{ Gene/protein } & \multirow[t]{2}{*}{ Effect } & \multicolumn{3}{|l|}{ Condition } & \multirow[t]{2}{*}{ Reference } \\
\hline & & & Changed by $\mathrm{T} 2 \mathrm{D}$ & $\begin{array}{l}\text { Affecting T2D } \\
\text { development }\end{array}$ & ND & \\
\hline \multirow[t]{5}{*}{ High carbohydrate } & FoxO1 [protein] & Dephosphorylated & & $\checkmark$ & & [13] \\
\hline & Scdl [gene] & Increase of expression & & & $\checkmark$ & [36] \\
\hline & ATF4 [gene] & Increase of expression & & $\checkmark$ & & [48] \\
\hline & INSIG1 [gene] & Reduction of expression & & $\checkmark$ & & {$[90]$} \\
\hline & FoxOl [gene] & Increase of expsion & & $\checkmark$ & & {$[90]$} \\
\hline \multirow[t]{23}{*}{ High-MSG } & GLUT4 [protein] & $\begin{array}{l}\text { Reduction of expression accompanied with whole- } \\
\text { body insulin resistance and increased plasma } \\
\text { a ncentration of inflammatory markers }\end{array}$ & & & $\checkmark$ & [91] \\
\hline & slc $2 a 4$ [gene] & $\begin{array}{l}\text { Reduction of expression that contributes to the } \\
\text { impairment of glycemic homeostasis }\end{array}$ & & & $\checkmark$ & [92] \\
\hline & Slc $2 a 2$ [gene] & $\begin{array}{l}\text { Increase of the content and collaboration with } \\
\text { nonalcoholic steat ohepatitis to facilitate the glucose } \\
\text { input to hepatocyte }\end{array}$ & & & $\checkmark$ & [93] \\
\hline & $p c k 1$ [gene] & Increase of expression level & & & $\checkmark$ & {$[94,95]$} \\
\hline & $\begin{array}{l}\text { PPAR } \alpha \text { and } \\
\text { PPAR } \gamma \text { [protein] }\end{array}$ & $\begin{array}{l}\text { Increase of the level and creation of inflammatory } \\
\text { effect(s) }\end{array}$ & & & $\checkmark$ & [66] \\
\hline & ACO [protein] & Lowered expression might cause obesity & & & $\checkmark$ & [96] \\
\hline & $C P T 1$ [gene] & $\begin{array}{l}\text { Increase of expression level possibly leading to } \\
\text { obesity }\end{array}$ & & & $\checkmark$ & [97] \\
\hline & PDK4 [gene] & Increase of muscle PDK4 expression & & & $\checkmark$ & [98] \\
\hline & $T I F 2$ [gene] & Deletion of this gene protects mice from obese & & & $\checkmark$ & [75] \\
\hline & $S R C 1$ [gene] & Antagonist of $T I F 2^{-}$ & & & $\checkmark$ & [76] \\
\hline & $P G C-1 \alpha$ & $\begin{array}{l}\text { Activation at neonatal period reduced } P D X 1 \\
\text { expression and pancreas maturation }\end{array}$ & & & $\checkmark$ & [99] \\
\hline & SIRT1 [gene] & $\begin{array}{l}\text { Increase of this gene expression alleviates symptoms } \\
9 \text { the already diabetic patient }\end{array}$ & & & $\checkmark$ & {$[81]$} \\
\hline & slc $2 a 4$ [gene] & $\begin{array}{l}\text { Reduction of expression that contributes to the } \\
\text { impairment of glycemic homeostasis }\end{array}$ & & & $\checkmark$ & [92] \\
\hline & Slc $2 a 2$ [gene] & $\begin{array}{l}\text { Increase of the content and collaboration with } \\
\text { nonalcoholic steatohepatitis to facilitate the glucose } \\
\text { input to hepatocyte }\end{array}$ & & & $\checkmark$ & [93] \\
\hline & $p c k l$ [gene] & Increase of expression level & & & $\checkmark$ & {$[94,95]$} \\
\hline & $\begin{array}{l}\text { PPAR } \alpha \text { and } \\
\text { PPAR } \gamma \text { [protein] }\end{array}$ & $\begin{array}{l}\text { Increase of the level and creation of inflammatory } \\
\text { effect(s) }\end{array}$ & & & $\checkmark$ & [66] \\
\hline & ACO [protein] & Lowered expression might cause obesity & & & $\checkmark$ & [96] \\
\hline & $C P T 1$ [gene] & $\begin{array}{l}\text { Increase of expression level possibly leading to } \\
\text { obesity }\end{array}$ & & & $\checkmark$ & [97] \\
\hline & PDK4 [gene] & Increase of muscle PDK4 expression & & & $\checkmark$ & [98] \\
\hline & $T I F 2$ [gene] & $\begin{array}{l}\text { Deletion of this gene protects mice from } \\
\text { getting obese }\end{array}$ & & & $\checkmark$ & [75] \\
\hline & $S R C 1$ [gene] & Antagonist of $T I F 2^{-}$ & & & $\checkmark$ & [76] \\
\hline & $P G C-1 \alpha$ & $\begin{array}{l}\text { Activation at neonatal period reduces } P D X I \\
\text { expression and pancreas maturation }\end{array}$ & & & $\checkmark$ & [99] \\
\hline & SIRTI [gene] & $\begin{array}{l}\text { Increase of this gene expression alleviates symptoms } \\
\text { in the already diabetic patient }\end{array}$ & & & $\checkmark$ & {$[81]$} \\
\hline
\end{tabular}

population in Japan consume white rice and MSG-enriched food like people in other Asian countries, uniquely, Japan is projected to have only a small increase in the ratio of its diabetic people in 2025. This fact might be due to the nationwide health guidance and lifestyle intervention program [107-109]. 
While studies on epidemiology related to highcarbohydrate diet related to the risk of T2D development are clearly [18, 102-105], findings about human population study at risk of high-MSG diet are inconsistent. Studies on MSG-related diabetic cases have been frequently reported using animal models. There is a lack of epidemiological data of MSG consumption which contribute to T2D in comparison to those of high-carbohydrate consumption. Epidemiology in Spanish population has been linked to the increasing risks of getting T2D to cardiovascular diseases due to high glutamate plasma level [110]. Based on another epidemiology in Thailand, daily consumption exceeding $5 \mathrm{~g}$ of MSG is considered risky to carry metabolic disorders, including T2D [111]. MSG intakes have also been reported to increase the 12 dence of overweight [112]. However, two studies from the Jiangsu Nutrition Study argued 12 MSG intake did not correlate with obesity, and even high MSG intake was negatively associated with hyperglycemia [113, 114].

One possible explanation that could explain the opposing results among the studies of epidemiology is the unready transportation from the intestine into the blood circulation in contrast to various experimental data that used MSGinduced diabetic mice models by MSG subcutaneous injection [51, 115]. Another explanation arises from experimental data where life period is an important factor related to the genetic programming by environmental factors. Mice at the age of 4 months old with high-MSG diet are prone to various metabolic disorders, including the increased signs of glucose intolerance. However, along with the aging process, the impairment of metabolism from the obesity effects can be attenuated [116].

By considering both experimental data from animal or cell culture studies with epidemiological data, we summarize that high-carbohydrate diet evidently positively correlates with T2D and could cause the onset of T2D. Although MSG studies are still in conflict with one another, we do not encourage people to slacken their diets by consuming high amount of MSG based on the experimental data of MSG potentials to alter homeostasis on carbohydrate and fat metabolism. All in all, lifestyle intervention shows to be a promising primary prevention of diabetes, and healthy lifestyle is shown to be comparable with metformin intake as reported by Indian Diabetes Prevention Program [104]. Govermental policies can play a huge role on combating the increasing prevalence of diabetes by encouraging a healthy diet and lifestyle, such as taxation program in Thailand for beverages which contain high level of sugar content [117].

\section{Conclusion and future perspectives}

High-fat diet is commonly known to induce T2D, especially in the case of high-carbohydrate and high-MSG diets. However, high-MSG diet requires longer time to develop hyperglycemia preceded by obesity. Various genes, especially genes related to glucose and fat metabolism are interrelated within these two diets. Branched signal transduction pathways and different phenotypes of each gene in different organs or ages revealed complicated mechanisms that should be taken as precautions as the targeted gene of interest to treat T2D or to construct a specific biomarker for T2D. Initially, some activated or repressed genes are only a feedback mechanism to control body homeostasis related to the imbalanced diet. For example, high-carbohydrate diet increased $S C D-1$ expression. Prolonged feedback mechanism often creates vicious cycle thus developing metabolic syndromes including obesity and T2D.

Increasing FoxOl and ATF4 expressions or their activation in high-carbohydrate-induced diabetic mice will lead to insulin resistance. It could be interesting to study the repression or the side effects of both genes of diabetic mice for long-term xperiments. Both genes might have potential uses as a biomarker for early detection of the T2D. The fact of MSG-induced diabetic mice often leads to the increase of gene expressions related to lipogenesis, such as PPARs family. However, the changes in PPARs expression and activation may disrupt the $b_{5}$ ance between glucose and lipid metabolism. Both TIF2 and SIRTI are promising genes in alleviating insulin resistance developed from MSGinduced diabetes. However, these strategis 30 have also exhibited some drawbacks. TIF 2 silencing increased the expression of PGC- $1 \alpha$ that inhibited the maturation of pancreas at neonatal period. Further information on $T I F 2$ silencing of pancreatic cells from various ages of mice models may enlighten the benefits of targeting TIF 2 as a gene of interest to treating T2D. It is still unclear how the MSG affects the TIF2 expression in $\beta$-cells. Similarly, SIRTI is indeed an interesting target gene, however, precautions should be taken in drug administration, diet lifestyle, and targeted organs. Otherwise, the disruption of the delicate balance of homeostasis may lead to worsening physical conditions. Studying the SIRTI signal transduction pathway and its effects on T2D in a more long-term experiment will shed more understanding into how SIRTI maintains homeostasis.

1 Ack 1 wledgements The research and writing of this paper was funded by Indonesia Ministry of Research, Technology, and Higher Education (021/SP-Lit/LPPM-01/DRPM/Multi/FTB/II/2019). We thank Helen Hendaria Kamandhari, Ph.D. for her editing and comments.

\section{Compliance with ethical standards}

Conflict of interest The authors declare that they have no conflict of interest. 
Ethical approval The studies conducted in this article do not involve human participants or animals.

Publisher's note Springer Nature remains neutral with regard to jurisdictional claims in published maps and institutional affiliations.

\section{References}

1. N. Cho, J.E. Shaw, S. Karuranga, Y. Huang, J.D. da Rocha Fernandes, A.W. Ohlrogge, B. Malanda, IDF Diabetes Atlas: Global estimates of diabetes prevalence for 2017 and projections for 2045. Diabetes Res. Clin. Pract. 138, 271-281 (2018)

2. S.K. Das, S.C. Elbein, The genetic basis of type 2 diabetes. Cellscience 2(4), 100-131 (2006)

3. J.C. Jimenez-Chillaron, M. Ramon-Krauel, S. Ribo, R. Diaz, Transgenerational epigenetic inheritance of diabetes risk as a consequence of early nutritional imbalances. Proc. Nutr. Soc. 75 (1), 78-89 (2015)

4. A. Alkhatib, C. Tsang, A. Tiss, T. Bahorun, H. Arefanian, R. Barake, Abdelkrim Khadir, J, danTuomilehto, Functional foods and lifestyle approaches for diabetes prevention and management. Nutrients 9(12), 1310 (2017)

5. Y. Sun, W. You, F. Almeida, P. Estabrooks, B. Davy, The effectiveness and cost of lifestyle interventions including nutrition education for diabetes prevention: a systematic review and meta-analysis. J. Acad. Nutr. Diet. 117(3), 404-421 e36 (2017)

6. S.E. Kahn, R.L. Hull, K.M. Utzschneider, Mechanisms linking obesity to insulin resistance and type 2 diabetes. Nature 444 (7121), 840 (2006)

7. C. Weyer, C. Bogardus, D.M. Mott, R.E. Pratley, The natural history of insulin secretory dysfunction and insulin resistance in the pathogenesis of type 2 diabetes mellitus. J. Clin. Investig. 104(6), 787-794 (1999)

8. M.Y. Donath, J.A. Ehses, K. Maedler, D.M. Schumann, H. Ellingsgaard, E. Eppler, M. Reinecke, Mechanisms of $\beta$-cell death in type 2 diabetes. Diabetes 54(Suppl 2), S108-S113 (2005)

9. P. Zimmet, Z. Shi, A. El-Osta, L. Ji, Epidemic T2DM, early development and epigenetics: implications of the Chinese Famine. Nat. Rev. Endocrinol. 14(12), 738-746 (2018)

10. M. Tian, C. Reichetzeder, J. Li, B. Hocher, Low birth weight, a risk factor for diseases in later life, is a surrogate of insulin resistance at birth. J. Hypertens. 37(11), 2123-2134 (2019)

11. E.R. Gilbert, Z. Fu, D. Liu, Development of a nongenetic mouse model of type 2 diabetes. Exp. Diabetes Res. 2011, 416254 (2011)

12. M. Manco, M. Calvani, G. Mingrone, Effects of dietary fatty acids on insulin sensitivity and secretion. Diabetes Obes. Metab. 6(6), 402-413 (2004)

13. O. Kluth, F. Mirhashemi, S. Scherneck, D. Kaiser, R. Kluge, S. Neschen, H.G. Joost, A. Schürmann, Dissociation of lipotoxicity and glucotoxicity in a mouse model of obesity associated diabetes: role of forkhead box $\mathrm{Ol}$ (FOXO1) in glucose-induced beta cell failure. Diabetologia 54(3), 605-616 (2011)

14. Y.B. Kim, S. Iwashita, T. Tamura, K. Tokuyama, M. Suzuki, Effect of high-fat diet on the gene expression of pancreatic GLUT2 and glucokinase in rats. Biochem. Biophys. Res. Commun. 208(3), 1092-1098 (1995)

15. Z. Liu, I.Y. Patil, T. Jiang, H. Sancheti, J.P. Walsh, B.L. Stiles, F. Yin, E. Cadenas, High-fat diet induces hepatic insulin resistance and impairment of synaptic plasticity. PloS ONE 10(5), e0128274 (2015)

16. S.E.D. Putra, S. Singajaya, F. Thesman, D.A. Pranoto, R. Sanjaya, Y.M. Vianney, I.B.M. Artadana, Aberrant PDK4 promoter methylation preceding hyperglycemia in a mouse model. Appl. Biochem. Biotechnol. (2019). https://doi.org/10.1007/s12010019-03143-6

17. S. Muthayya, J.D. Sugimoto, S. Montgomery, G.F. Maberly, An overview of global rice production, supply, trade, and consumption. Ann. N. Y. Acad. Sci. 1324(1), 7-14 (2014)

18. Y. Li, D.D. Wang, S.H. Ley, M. Vasanti, A.G. Howard, Y. He, F.B. Hu, Time trends of dietary and lifestyle factors and their potential impact on diabetes burden in China. Diabetes Care 40 (12), 1685-1694 (2017)

19. E.A. Hu, A. Pan, V. Malik, Q. Sun, White rice consumption and risk of type 2 diabetes: meta-analysis and systematic review. BMJ 344, el454 (2012)

20. V. Mohan, G. Radhika, P. Vijayalakshmi, V. Sudha, Can the diabetes/cardiovascular disease epidemic in India be explained, at least in part, by excess refined grain (rice) intake? Indian J. Med. Res. 131, 369-372 (2010)

21. M. Balakumar, L. Raji, D. Prabhu, C. Sathishkumar, P. Prabu, V. Mohan, M. Balasubramanyam, High-fructose diet is as detrimental as high-fat diet in the induction of insulin resistance and diabetes mediated by hepatic/pancreatic endoplasmic reticulum (ER) stress. Mol. Cell. Biochem. 423(1-2), 93-104 (2016)

22. M.E. Bizeau, M.J. Pagliassotti, Hepatic adaptations to sucrose and fructose. Metabolism 54(9), 1189-1201 (2005)

23. M. Dirlewanger, P. Schneiter, E. Jéquier, L. Tappy, Effects of fructose on hepatic glucose metabolism in humans. Am. J. Physiol. Endocrinol. Metab. 279(4), E907-E911 (2000)

24. Y. Sasaki, W. Suzuki, T. Shimada, S. lizıka, S. Nakamura, M. Nagata, M. Fujimoto, K. Tsuneyama, R. Hokao, K. Miyamoto, M. Aburada, Dose dependent development of diabetes mellitus and non-alcoholic steatohepatitis in monosodium glutamateinduced obese mice. Life Sci. 85(13-14), 490-498 (2009)

25. J.F. Morrison, S. Shehab, R. Sheen, S. Dhanasekaran, M. Shaffiullah, E. Mensah-Brown, Sensory and autonomic nerve changes in the monosodium glutamate-treated rat: a model of type II diabetes. Exp. Physiol. 93(2), 213-222 (2008)

26. M. Nagata, W. Suzuki, S. Iizuka, M. Tabuchi, H. Maruyama, S. Takeda, M. Aburada, K.I. Miyamoto, Type 2 diabetes mellitus in obese mouse model induced by monosodium glutamate. Exp. Anim. 55(2), 109-115 (2006)

27. K. Beyreuther, H.K. Biesalski, J.D. Fernstrom, P. Grimm, W.P. Hammes, U. Heinemann, O. Kempski, P. Stehle, H. Steinhart, R. Walker, Consensus meeting: monosodium glutamate-an update. Eur. J. Clin. Nutr. 61(3), 304-313 (2007)

28. W. Prawirohardjono, I. Dwiprahasto, I. Astuti, S. Hadiwandowo, E. Kristin, M. Muhammad, M.F. Kelly, The administration to Indonesians of monosodium L-glutamate in Indonesian foods: an assessment of adverse reactions in a randomized double-blind, crossover, placebo-controlled study. J. Nutr. 130(4), 1074S-1076S (2000)

29. M. Srinivasan, R. Aalinkeel, F. Song, M.S. Patel, Programming of islet functions in the progeny of hyperinsulinemic/obese rats. Diabetes 52(4), 984-990 (2003)

30. R.A. Miranda, C.C. da Silva Franco, J.C. de Oliveira, L.F. Barella, L.P. Tófolo, T.A. Ribeiro, P.C. Lisboa, Cross-fostering reduces obesity induced by early exposure to monosodium glutamate in male rats. Endocrine 55(1), 101-112 (2017)

31. T. Kitamura, J. Nakae, Y. Kitamura, Y. Kido, W.H. Biggs, C.V. Wright, M.F. White, K.C. Arden, D. Accili, The forkhead transcription factor Foxol links insulin signaling to $\mathrm{Pdx} I$ regulation of pancreatic $\beta$ cell growth. J. Clin. Investig. 110(12), 1839-1847 (2002)

32. U. Ahlgren, J. Jonsson, L. Jonsson, K. Simu, H. Edlund, $\beta$-Cellspecific inactivation of the mouseIpfl/Pdx $\mathrm{l}$ gene results in loss of the $\beta$-cell phenotype and maturity onset diabetes. Genes Dev. 12(12), 1763-1768 (1998) 
33. G. Sethi, M.K. Shanmugam, A.P. Kumar, SREBP-Ic as a molecular bridge between lipogenesis and cell cycle progression of clear cell renal carcinoma. Biosci. Rep. 37(6), BSR20171270 (2017)

34. J.Y. Kim-Muller, Y.J.R. Kim, J. Fan, S. Zhao, A.S. Banks, M. Prentki, D. Accili, FoxOl deacetylation decreases fatty acid oxidation in $\beta$-cells and sustains insulin secretion in diabetes. J. Biol. Chem. 291(19), 10162-10172 (2016)

35. J.M. Ntambi, Dietary regulation of stearoyl-CoA desaturase 1 gene expression in mouse liver. J. Biol. Chem. 267(15), 10925-10930 (1992)

36. K.M. Waters, J.M. Ntambi, Insulin and dietary fructose induce stearoyl-CoA desaturase 1 gene expression of diabetic mice. J. Biol. Chem. 269(44), 27773-27777 (1994)

37. J.M. Ntambi, The regulation of stearoyl-CoA desaturase (SCD). Prog. Lipid Res. 34(2), 139-150 (1995)

38. M.E. Pape, F. Lopez-Casillas, K.H. Kim, Physiological regulation of acetyl-CoA carboxylase gene expression: effects of diet, diabetes, and lactation on acetyl-CoA carboxylase mRNA. Arch. Biochem. Biophys. 267(1), 104-109 (1988)

39. M.P. Rogowski, M.T. Flowers, A.D. Stamatikos, J.M. Ntambi, C.M. Paton, SCD1 activity in muscle increases triglyceride PUFA content, exercise capacity, and PPARס expression in mice. J. Lipid Res. 54(10), 2636-2646 (2013)

40. J. Drąg, A. Goździalska, M. Knapik-Czajka, A. Gawędzka, K. Gawlik, J. Jaśkiewicz, Effect of high carbohydrate diet on elongase and desaturase activity and accompanying gene expression in rat's liver. Genes Nutr. 12(1), 1-8 (2017)

41. M. Miyazaki, M.T. Flowers, H. Sampath, K. Chu, C. Otzelberger, X. Liu, J.M. Ntambi, Hepatic stearoyl-CoA desaturase-1 deficiency protects mice from carbohydrate-induced adiposity and hepatic steatosis. Cell Metab. 6(6), 484-496 (2007)

42. R. Gutiérrez-Juárez, A. Pocai, C. Mulas, H. Ono, S. Bhanot, B.P. Monia, L. Rossetti, Critical role of stearoyl-CoA desaturase-1 (SCD1) in the onset of diet-induced hepatic insulin resistance. J. Clin. Investig. 116, 1686-1695 (2006)

43. G. Jiang, Z. Li, F. Liu, K. Ellsworth, Q. Dallas-Yang, M. Wu, R Bergeron, Prevention of obesity in mice by antisense oligonucleotide inhibitors of stearoyl-CoA desaturase-1. J. Clin. Investig. 115(4), 1030-1038 (2005)

44. J.M. Ntambi, M. Miyazaki, J.P. Stoehr, H. Lan, C.M. Kendziorski, B.S. Yandell, Y. Song, P. Cohen, J.M. Friedman, A.D Attie, Loss of stearoyl-CoA desaturase-1 function protects mice against adiposity. Proc. Natl Acad. Sci. 99(17), 11482-11486 (2002)

45. M.T. Flowers, L. Ade, M.S. Strable, J.M. Ntambi, Combined deletion of SCD1 from adipose tissue and liver does not protect mice from obesity. J. Lipid Res. 53(8), 1646-1653 (2012)

46. H. Li, Q. Meng, F. Xiao, S. Chen, Y. Du, J. Yu, C. Wang, F. Guo, ATF4 deficiency protects mice from high-carbohydratediet-inducced liver steatosis. Biochem. J. 438 $(2)$, 283-289 (2011)

47. J. Seo, E.S. Fortuno, J.M. Suh, D. Stenesen, W. Tang, E.J. Parks, C.M. Adams, T. Townes, J.M. Graff, Atf4 regulates obesity, glucose homeostasis, and energy expenditure. Diabetes 58(11), 2565-2573 (2009)

48. G. Xiao, T. Zhang, S. Yu, S. Lee, V. Calabuig-Navarro, J. Yamauchi, S. Ringquist, H.H. Dong, ATF4 protein deficiency protects against high fructose-induced hypertriglyceridemia in mice. J. Biol. Chem. 288(35), 25350-25361 (2013)

49. K. Li, J. Zhang, J. Yu, B. Liu, Y. Guo, J. Deng, S. Chen, S. Wang, F. Guo, MicroRNA-214 suppresses gluconeogenesis by targeting activating transcriptional factor 4 . J. Biol. Chem. 290 (13), 8185-8195 (2015)

50. X. Zhu, H. Li, Y. Wu, J. Zhou, G. Yang, W. Wang, IncRNA MEG3 promotes hepatic insulin resistance by serving as a competing endogenous RNA of miR-214 to regulate ATF4 expression. Int. J. Mol. Med. 43(1), 345-357 (2019)

51. D.G. Burrin, B. Stoll, Metabolic fate and function of dietary glutamate in the gut. Am. J. Clin. Nutr. 90(3), 850S-856S (2009)

52. L.D. Stegink, W.A. Reynolds, L.J. Filer Jr, R.M. Pitkin, D.P. Boaz, M.C. Brummel, Monosodium glutamate metabolism in the neonatal monkey. Am. J. Physiol. 229(1), 246-250 (1975)

53. M. Shannon, J. Wilson, Y. Xie, L. Connolly, In vitro bioassay investigations of suspected obesogen monosodium glutamate at the level of nuclear receptor binding and steroidogenesis. Toxicol. Lett. 301, 11-16 (2019)

54. L.L. Kjems, J.J. Holst, A. Vølund, S. Madsbad, The influence of GLP-1 on glucose-stimulated insulin secretion: effects on $\beta$-cell sensitivity in type 2 and nondiabetic subjects. Diabetes 52(2), 380-386 (2003)

55. M. Shannon, B. Green, G. Willars, J. Wilson, N. Matthews, J. Lamb, A. Gillespie, L. Connolly, The endocrine disrupting potential of monosodium glutamate (MSG) on secretion of the glucagon-like peptide-1 (GLP-1) gut hormone and GLP-1 receptor interaction. Toxicol. Lett. 265, 97-105 (2017)

56. G.S. Hotamisligil, B.M. Spiegelman, Tumor necrosis factor $\alpha$ : a key component of the obesity-diabetes link. Diabetes $43(11)$ 1271-1278 (1994)

57. G.S. Hotamisligil, N.S. Shargill, B.M. Spiegelman, Adipose expression of tumor necrosis factor-alpha: direct role in obesitylinked insul in resistance. Science 259(5091), 87-91 (1993)

58. U.F. Machado, Y. Shimizu, M. Saito, Decreased glucose transporter (GLUT 4) content in insulin-sensitive tissues of obese aurothioglucose-and monosodium glutamate-treated mice. Horm. Metab. Res. 25(09), 462-465 (1993)

59. C.Y. Yonamine, A.B. Alves-Wagner, J.V. Esteves, M.M. Okamoto, M.L. Correa-Giannella, D. Giannella-Neto, U.F. Machado, Diabetes induces tri-methylation at lysine 9 of histone 3 at Slc2a 4 gene in skeletal muscle: A new target to improve glycemic control. Mol. Cell. Endocrinol. 481, 26-34 (2019)

60. C. Yonamine, E. Pinheiro-Machado, M. Michalani, A. AlvesWagner, J. Esteves, H. Freitas, U. Machado, Resveratrol improves glycemic control in type 2 diabetic obese mice by regulating glucose transporter expression in skeletal muscle and liver. Molecules 22(7), 1180 (2017)

61. S. vio Brandelero Jr, M.L. ciaBonfleur, R.A. Ribeiro, E.C Vanzela, C.A. Nassar, P.O. Nassar, S.L. Balbo, Decreased TNFa gene expression in periodontal ligature in MSG-obese rats: A possible protective effect of hypothalamic obesity against periodontal disease?. Arch. Oral. Biol. 57(3), 300-306 (2011)

62. M.S. Islam, T. du Loots, Experimental rodent models of type 2 diabetes: a review. Methods Find. Exp. Clin. Pharmacol. 31(4), 249-261 (2009)

63. A.E. Hirata, I.S.D. Andrade, P. Vaskevicius, M.S. Dolnikoff, Monosodium glutamate (MSG)-obese rats develop glucose intolerance and insulin resistance to peripheral glucose uptake. Braz. J. Med. Biol. Res, 30, 671-67 (1997)

64. S.N. Liu, Q. Liu, L.Y. Li, Y. Huan, S J. Sun, Z.F. Shen, Longterm fenofibrate treatment impaired glucose-stimulated insulin secretion and up-regulated pancreatic NF-kappa B and iNOS expression in monosodium glutamate-induced obese rats: Is that a latent disadvantage? J. Transl. Med. 9(1), 176 (2011)

65. P.P. Li, S. Shan, Y.T. Chen, Z.Q. Ning, S.J. Sun, Q. Liu, X.P. Lu, M.Z. Xie, Z.F. Shen, The PPAR $\alpha / \gamma$ dual agonist chiglitazar improves insulin resistance and dyslipidemia in MSG obese rats. Br. J. Pharmacol. 148(5), 610-618 (2006)

66. R. Roman-Ramos, J.C. Almanza-Perez, R. Garcia-Macedo, G. Blancas-Flores, A. Fortis-Barrera, E.I. Jasso, M. GarciaLorenzana, A.E. Campos-Sepulveda, M. Cruz, F.J. AlarconAguilar, Monosodium glutamate neonatal intoxication associated 
with obesity in adult stage is characterized by chronic inflammation and increased mrna expression of peroxisome proliferator-activated receptors in mice. Basic Clin. Pharmacol. Toxicol. 108(6), 406-413 (2011)

67. D.S. Pan, W. Wang, N.S. Liu, Q.J. Yang, K. Zhang, J.Z. Zhu, S. Shan, Z.B. Li, Z.Q. Ning, L. Huang, X.P. Lu, Chiglitazar preferentially regulates gene expression via configuration-restricted binding and phosphorylation inhibition of PPAR $\gamma$. PPAR Res. 2017, 4313561 (2017)

68. K.A. Burns, J.P.V. Heuvel, Modulation of PPAR activity via phosphorylation. Biochim. Biophys. Acta. 1771(8), 952-960 (2007)

69. E. Hu, J.B. Kim, P. Sarraf, B.M. Spiegelman, Inhibition of adipogenesis through MAP kinase-mediated phosphorylation of PPAR $\gamma$. Science 274(5295), 2100-2103 (1996)

70. M.J. Lafferty, K.C. Bradford, D.A. Erie, S.B. Neher, Angiopoietin-like protein 4 inhibition of lipoprotein lipase evidence for reversible complex formation. J. Biol. Chem. 288(40), 28524-28534 (2013)

71. S.D. van Otterdijk, A.M. Binder, K.S. vel Szic, J. Schwald, K.B. Michels, DNA methylation of candidate genes in peripheral blood from patients with type 2 diabetes or the metabolic syndrome. PloS ONE 12(7), e0180955 (2017)

72. A.J. McAinch, L.M. Cornall, R. Watts, D.H. Hryciw, P.E. O'Brien, D. Cameron-Smith, Increased pyruvate dehydrogenase kinase expression in cultured myotubes from obese and diabetic individuals. Eur. J. Nutr. 54(7), 1033-1043 (2015)

73. A. Georgiadi, L. Lichtenstein, T. Degenhardt, M. Boekschoten, M. van Bilsen, B. Desvergne, M. Müller, S. Kersten, Induction of cardiac Angptl4 by dietary fatty acids is mediated by peroxisome proliferator-activated receptor $\beta / \delta$ and protects against fatty acid-inducedoxidative stress. Circ. Res. 106(11), $1712-1721$ (2009)

74. K. Chokkalingam, K. Jewell, L. Norton, J. Littlewood, L.J.C. Van Loon, P. Mansell, LA. Macdonald, K. Tsintzas, High-fat/lowcarbohydrate diet reduces insulin-stimulated carbohydrate oxidation but stimulates nonoxidative glucose disposal in humans: an important role for skeletal muscle pyruvate dehydrogenase kinase 4. J. Clin. Endocrinol. Metab. 92(1), 284-292 (2007)

75. F. Picard, M. Géhin, J.S. Annicotte, S. Rocchi, M.F. Champy, B. W. O'Malley, P. Chambon, J. Auwerx, SRC-1 and TIF2 control energy balance between white and brown adipose tissues. Cell 111(7), 931-941 (2002)

76. D. Duteil, C. Chambon, F. Ali, R. Malivindi, J. Zoll, S. Kato, B. Geny, P. Chambon, D. Metzger, The transcriptional coregulators TIF2 and SRC-1 regulate energy homeostasis by modulating mitochondrial respiration in skeletal muscles. Cell Metab. 12(5), 496-508 (2010)

77. C. Tiraby, G. Tavernier, F. Capel, A. Mairal, F. Crampes, J. Rami, C. Pujol, J.A. Boutin, D. Langin, Resistance to high-fatdiet-induced obesity and sexual dimorphism in the metabolic responses of transgenic mice with moderate uncoupling protein 3 overexpression in glycolytic skeletal muscles. Diabetologia $\mathbf{5 0}$ (10), 2190-2199 (2007)

78. A. Besseiche, J.P. Riveline, J.F. Gautier, B. Breant, B. Blondeau, Metabolic roles of PGC- $1 \alpha$ and its implications for type 2 diabetes. Diabetes Metab. 41(5), 347-357 (2015)

79. A. Coste, J.F. Louet, M. Lagouge, C. Lerin, M.C. Antal, H. Meziane, K. Schoonjans, P. Puigserver, B.W. O'Malley, J. Auwerx, The genetic ablation of SRC-3 protects against obesity and improves insulin sensitivity by reducing the acetylation of PGC-1 $\alpha$. Proc. Natl Acad. Sci. 105(44), $17187-17192$ (2008)

80. B. Valtat, J.P. Riveline, P. Zhang, A. Singh-Estivalet, M. Armanet, N. Venteclef, A. Besseiche, D.P. Kelly, F. Tronche, P. Ferné, J.F. Gautier, B. Bréant, J.F. Gautier, Fetal PGC-1 $\alpha$ overexpression programs adult pancreatic $\beta$-cell dysfunction. Diabetes $62(4), 1206-1216(2013)$
81. Y. Cao, X. Jiang, H. Ma, Y. Wang, P. Xue, Y. Liu, SIRT1 and insulin resistance. J. Diabetes Complic. 30(1), 178-183 (2016)

82. T. Yoshizaki, S. Schenk, T. Imamura, J.L. Babendure, N. Sonoda, E.J. Bae, D.Y. Oh, M. Lu, J.C. Milne, C. Westphal, G. Bandyopadhyay, G. Bandyopadhyay, SIRT1 inhibits inflammatory pathways in macrophages and modulates insulin sensitivity. Am. J. Physiol. Endocrinol. Metab. 298(3), E419-E428 (2009)

83. R.H. Wang, H.S. Kim, C. Xiao, X. Xu, O. Gavrilova, C.X. Deng, Hepatic Sirtl deficiency in mice impairs mTorc2/Akt signaling and results in hyperglycemia, oxidative damage, and insulin resistance. J. Clin. Investig. 121(11), 4477-4490 (2011)

84. MJ. Kim, H.J. An, D.H. Kim, B. Lee, HJ. Lee, S. Ullah, S.J. Kim, H.O. Jeong, K.M. Moon, E.K. Lee, J. Yang, J. Akter, P. Chun, H.R. Moon, J. Yang, Novel SIRT1 activator MHY2233 improves glucose tolerance and reduces hepatic lipid accumulation in $\mathrm{db} / \mathrm{db}$ mice. Bioorg. Med. Chem. Lett. 28(4), 684-688 (2018)

85. Y. Yamazaki, I. Usui, Y. Kanatani, Y. Matsuya, K. Tsuneyama, S. Fujisaka, A. Bukhari, H. Suzuki, S. Senda, S. Imanishi, K. Hirata, M. Ishiki, R. Hayashi, M. Urakaze, H. Nemoto, M. Kobayashi, K. Hirata, Treatment with SRT1720, a SIRT1 activator, ameliorates fatty liver with reduced expression of lipogenic enzymes in MSG mice. Am. J. Physiol. Endocrinol. Metab. 297(5), E1179-E1 186 (2009)

86. R.E. Gilbert, K. Thai, S.L. Advani, C.L. Cummins, D.M. Kepecs, S.A. Schroer, M. Woo, Y. Zhang, SIRT1 activation ameliorates hyperglycaemia by inducing a torpor-like state in an obese mouse model of type 2 diabetes. Diabetologia 58(4), 819-827 (2015)

87. D.M. Erion, S. Yonemitsu, Y. Nie, Y. Nagai, M.P. Gillum, J.J. Hsiao, T. Iwasaki, R. Stark, D. Weismann, X.X. Yu, S.F. Murray, S. Bhanot, B.P. Monia, T.L. Horvath, Q. Gao, V.T. Samuel, S.F. Murray, SIRT1 knockdown in liver decreases basal hepatic glucose production and increases hepatic insulin responsiveness in diabetic rats. Proc. Natl Acad. Sci. 106(27), 11288-11293 (2009)

88. J.T. Rodgers, P. Puigserver, Fasting-dependent glucose and lipid metabolic response through hepatic sirtuin 1. Proc. Natl Acad. Sci. 104(31), 12861-12866 (2007)

89. D. Wei, R. Tao, Y. Zhang, M.F. White, X.C. Dong, Feedback regulation of hepatic gluconeogenesis through modulation of SHP/Nr0b2 gene expression by Sirtl and FoxO1. Am. J. Physiol. Endocrinol. Metab. 300(2), E312-E320 (2010)

90. N. Sud, H. Zhang, K. Pan, X. Cheng, J. Cui, Q. Su, Aberrant expression of microRNA induced by high-fructose diet: implications in the pathogenesis of hyperlipidemia and hepatic insulin resistance. J. Nutr. Biochem. 43, 125-131 (2017). https://doi.org/ 10.1016/j.jnutbio.2017.02.003

91. N.M. Leguisamo, A.M. Lehnen, U.F. Machado, M.M. Okamoto, M.M. Markoski, G.H. Pinto, B.D. Schaan, GLUT4 content decreases along with insulin resistance and high levels of inflammatory markers in rats with metabolic syndrome. Cardiovasc Diabetol. 11(1), 100 (2012)

92. A.C. Poletto, A. David-Silva, A.P. Yamamoto, M. de, U.F. Machado, D.T. Furuya, Reduced S1c2a4/GLUT4 expression in subcutaneous adipose tissue of monosodium glutamate obese mice is recovered after atorvastatin treatment. Diabetol. Metab. Syndr. 7(1), 18 (2015)

93. A.D. Silva, R.R. Favaro, D.T. Furuya, P.E. Silva, L.T. Belpiede, H.S. Freitas, M.M. Okamoto, F. Barrance, T.M. Zorn, U.F. Machado, Overexpression of GLUT2/ Slc2a 2 are accompanied by Hnf- $1 \alpha$, Hnf- $4 \alpha$ and Hnf- $3 \beta$ transcriptional. J. Liver, 4 (3) (2015)

94. K.S. Collison, M.Z. Zaidi, S.M. Saleh, N.J. Makhoul, A. Inglis, J. Burrows, J.A. Araujo, F.A. Al-Mohanna, Nutrigenomics of 
hepatic steatosis in a feline model: effect of monosodium glutamate, fructose, and trans-fat feeding. Genes Nutr. 7(2), 265-280 (2011)

95. E.G. Beale, R.E. Hammer, B. Antoine, C. Forest, Disregulatedglyceroneogenesis: $\mathrm{PCK} 1$ as a candidate diabetes and obesity gene. Trends Endocrinol. Metab. 15(3), 129-135 (2004)

96. K.S. Collison, Z. Maqbool, S.M. Saleh, A. Inglis, N.J. Makhoul, R. Bakheet, M. Al-Johi, R. Al-Rabiah, M.Z. Zaidi, F.A. AlMohanna, Effect of dietary monosodium glutamate ontransfatinduced nonalcoholic fatty liver disease. J. Lipid Res. 50(8), 1521-1537 (2008)

97. K.S. Collison, N.J. Makhoul, M.Z. Zaidi, A. Inglis, B.L. Andres, R. Ubungen, S. Saleh, F.A. Al-Mohanna, Prediabetic changes in gene expression induced by aspartame and monosodium glutamate in trans fat-fed C57Bl/6 J mice. Nutr. Metab. 10(1), 44 (2013)

98. K.S. Collison, Z.M. Maqbool, A.L. Inglis, N.J. Makhoul, S.M Saleh, R.H. Bakheet, M.A. Al-Johi, R.K. Al-Rabiah, M.Z. Zaidi, F.A. Al-Mohanna, Effect of dietary monosodium glutamate on HFCS-induced hepatic steatosis: expression profiles in the liver and visceral fat. Obesity 18(6), 1122-1134 (2010)

99. H. Wu, X. Deng, Y. Shi, Y. Su, J. Wei, H. Duan, PGC-1 $\alpha$, glucose metabolism and type 2 diabetes mellitus. J. Endocrinol. 229(3), R99-R115 (2016)

100. Y. Zheng, S.H. Ley, F.B. Hu, Global aetiology and epidemiology of type 2 diabetes mellitus and its complications. Nat. Rev. Endocrinol. 14(2), 88 (2018)

101. M. Sakurai, K. Nakamura, K. Miura, T. Takamura, K. Yoshita, S.Y. Nagasawa, H. Nakagawa, Dietary carbohydrate intake, presence of obesity and the incident risk of type 2 diabetes in Japanese men. J. Diabetes Investig. 7(3), 343-351 (2016)

102. A. Khawaja, S. Qassim, N. Hassan, E.S.A. Arafa, Added sugar: nutritional knowledge and consumption pattern of a principal driver of obesity and diabetes among undergraduates in UAE. Diabetes Metab. Syndr. Clin. Res. Rev. 13(4), 2579-2584 (2019)

103. A. Nanditha, R.C. Ma, A. Ramachandran, C. Snehalatha, J.C. Chan, K.S. Chia, J.E. Shaw, P.Z. Zimmet, Diabetes in Asia and the Pacific: implications for the global epidemic. Diabetes Care 39(3), 472-485 (2016)

104. A. Ramachandran, C. Snehalatha, S. Mary, B. Mukesh, A.D Bhaskar, V. Vijay, The Indian Diabetes Prevention Programme shows that lifestyle modification and metformin prevent type 2 diabetes in Asian Indian subjects with impaired glucose tolerance (IDPP-1). Diabetologia 49(2), 289-297 (2006)

105. L.S. Gross, L. Li, E.S. Ford, S. Liu, Increased consumption of refined carbohydrates and the epidemic of type 2 diabetes in the United States: an ecologic assessment. Am. J. Clin. Nutr. 79(5), 774-779 (2004)

106. M.B. Schulze, J.E. Manson, D.S. Ludwig, G.A. Colditz, M.J. Stampfer, W.C. Willett, F.B. Hu, Sugar-sweetened beverages, weight gain, and incidence of type 2 diabetes in young and middle-aged women. JAMA 292(8), 927-934 (2004)
107. J.C. Chan, V. Malik, W. Jia, T. Kadowaki, C.S. Yajnik, K.H. Yoon, F.B. Hu, Diabetes in Asia: epidemiology, risk factors, and pathophysiology. JAMA 301(20), 2129-2140 (2009)

108. K. Tsushita, A.S. Hosler, K. Miura, Y. Ito, T. Fukuda, A Kitamura, K. Tatara, Rationale and descriptive analysis of specific health guidance: the nationwide lifestyle intervention program targeting metabolic syndrome in Japan. J. Atheroscler. Thromb 25(4), 308-322 (2018)

109. K. Kosaka, M. Noda, T. Kuzuya, Prevention of type 2 diabetes by lifestyle intervention: a Japanese trial in IGT males. Diabetes Res. Clin. Pract. 67(2), 152-162 (2005)

110. X. Liu, Y. Zheng, M. Guasch-Ferré, M. Ruiz-Canela, E. Toledo, C. Clish, L. Liang, C. Razquin, D. Corella, R. Estruch, M. Fito, E. Gómez-Gracia, F. Arós, E. Ros, J. Lapetra, M. Fiol, L. Serra-Majem, C. Papandreou, M.A. Martínez-González, F.B. Hu, J. Salas-Salvadó, High plasma glutamate and low glutamine-to-glutamate ratio are associated with type 2 diabetes: case-cohort study within the PREDIMED trial. Nutr. Metab. Cardiovasc. Dis. 29(10), 1040-1049 (2019)

111. T. Insawang, C. Selmi, U. Cha'on, S. Pethlert, P. Yongvanit, P. Areejitranusorn, P. Boonsiri, T. Khampitak, R. Tangrassameeprasert, C. Pinitsoontorn, V. Prasongwattana, M.E. Gershwin, V. Prasongwattana, Monosodium glutamate (MSG) intake is associated with the prevalence of metabolic syndrome in a rural Thai population. Nutr. Metab. 9(1), 50 (2012)

112. K. He, S. Du, P. Xun, S. Sharma, H. Wang, F. Zhai, B. Popkin, Consumption of monosodium glutamate in relation to incidence of overweight in Chinese adults: China Health and Nutrition Survey (CHNS). Am. J. Clin. Nutr. 93(6), $1328-1336$ (2011)

113. Z. Shi, N.D. Luscombe-Marsh, G.A. Wittert, B. Yuan, Y. Dai, X. Pan, A.W. Taylor, Monosodium glutamate is not associated with obesity or a greater prevalence of weight gain over 5 years: findings from the Jiangsu Nutrition Study of Chinese adults. Br. J. Nutr. 104(3), 457-463 (2010)

114. Z. Shi, A.W. Taylor, B. Yuan, H. Zuo, G.A. Wittert, Monosodium glutamate intake is inversely related to the risk of hyperglycemia. Clin. Nutr. 33(5), 823-828 (2014)

115. J.T. Brosnan, A. Drewnowski, M.I. Friedman, Is there a relationship between dietary MSG obesity in animals or humans? Amino Acids 46(9), 2075-2087 (2014)

116. R. Hernández-Bautista, F. Alarcón-Aguilar, D.C. EscobarVillanueva, J. Almanza-Pérez, H. Merino-Aguilar, M. Fainstein, N. López-Diazguerrero, Biochemical alterations during the obese-aging process in female and male monosodium glutamate (MSG)-treated mice. Int. J. Mol. Sci. 15(7), 11473-11494 (2014)

117. V. Chavasit, W. Kriengsinyos, J. Photi, K. Tontisirin, Trends of increases in potential risk factors and prevalence rates of diabetes mellitus in Thailand. Eur. J. Clin. Nutr. 71(7), 839 (2017) 
Emantoko_High_Carbohydrate.pdf

ORIGINALITY REPORT

$11 \% \quad 8 \%$

SIMILARITY INDEX

INTERNET SOURCES

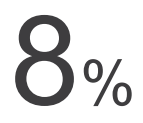

PUBLICATIONS
$4 \%$

STUDENT PAPERS

PRIMARY SOURCES

1 link.springer.com

2 Chen Fang, Yun Huang, Heming Guo, Yihui Sun, Hui Li, Xuna Bian, Haixia Guan, Ji Hu. "Mechanism of higher risk for COVID-19 in diabetes: a mask to lift", Endocrine, 2020 Publication

3 www.nature.com

4 wWW.mdpi.com

5 Submitted to University of Leeds Student Paper

Sulistyo Emantoko Dwi Putra, Stephanie Singajaya, Ferensia Thesman, Dicky Andhika Pranoto et al. "Aberrant PDK4 Promoter Methylation Preceding Hyperglycemia in a Mouse Model", Applied Biochemistry and Biotechnology, 2019 
7 Submitted to Chapman University

8 Islets of Langerhans, 2015.

9 Gorogawa, S.i.. "Insulin secretory defects and impaired islet architecture in pancreatic @b-cellspecific STAT3 knockout mice", Biochemical and Biophysical Research Communications, 20040709

Publication

10 Submitted to East Tennessee State University Student Paper

11 cardiab.biomedcentral.com

12 Shi, Zumin, Gary A. Wittert, Baojun Yuan, Yue Dai, Tiffany K. Gill, Gang Hu, Robert Adams, Hui Zuo, and Anne W. Taylor. "Association between monosodium glutamate intake and sleep-disordered breathing among Chinese adults with normal body weight", Nutrition, 2013. Publication

Thomas, David J., and Karen Bradham. "Role of complex organic arsenicals in food in aggregate exposure to arsenic", Journal of Environmental Sciences, 2016. 
14 www.reportworld.co.kr

15 everestbiotech.com

16 archive.org

17 pubs.rsc.org

18 Akieda-Asai, S., S. Koda, M. Sugiyama, K.

Hasegawa, M. Furuya, M. Miyazato, and Y.

Date. "Metabolic features of rats resistant to a

high-fat diet", Obesity Research \& Clinical

Practice, 2013.

Publication

s3.amazonaws.com

Selina Ahmed, Mohammed Abul Kashem,

Ranjana Sarker, Eakhlas U. Ahmed, Garth A.

Hargreaves, lain S. McGregor.

"Neuroadaptations in the Striatal Proteome of the Rat Following Prolonged Excessive Sucrose Intake", Neurochemical Research, 2014 Publication

Gilbert, Elizabeth. R., and Dongmin Liu. "Antidiabetic functions of soy isoflavone genistein: mechanisms underlying its effects on pancreatic 
$\beta$-cell function", Food \& Function, 2013.

Publication

22 Sampath, Harini, and James M. Ntambi.

"POLYUNSATURATED FATTY ACID

REGULATION OF GENES OF LIPID

METABOLISM", Annual Review of Nutrition,

2005.

Publication

23 joe.bioscientifica.com

Internet Source

24 www.tandfonline.com

Internet Source

25 www.science.gov

Internet Source

26 worldwidescience.org

Internet Source

27 en.wikipedia.org

28 www.e-sciencecentral.org

29 www.jove.com

30 John E. Dominy, Yoonjin Lee, Zachary GerhartHines, Pere Puigserver. "Nutrient-dependent regulation of PGC-1 $\alpha$ 's acetylation state and 
metabolic function through the enzymatic

activities of Sirt1/GCN5", Biochimica et

Biophysica Acta (BBA) - Proteins and

Proteomics, 2010

Publication

31 Handbook of Experimental Pharmacology,

2016.

32 M. Balakumar, L. Raji, D. Prabhu, C.

Sathishkumar, P. Prabu, V. Mohan, M.

Balasubramanyam. "High-fructose diet is as detrimental as high-fat diet in the induction of insulin resistance and diabetes mediated by hepatic/pancreatic endoplasmic reticulum (ER) stress", Molecular and Cellular Biochemistry, 2016

Robert H. Lustig. "Fructose: Metabolic, Hedonic, and Societal Parallels with Ethanol", Journal of the American Dietetic Association, 2010 Publication

Antonio Zorzano, Tomàs Santalucia, Manuel

Palacín, Anna Gumà, Marta Camps. "Searching

for Ways to Upregulate GLUT4 Glucose

Transporter Expression in Muscle", General

Pharmacology: The Vascular System, 1998 
35 Shannon, Maeve, Brian Green, Gary Willars, Jodie Wilson, Natalie Matthews, Joanna Lamb,

Anna Gillespie, and Lisa Connolly. "The

endocrine disrupting potential of monosodium

glutamate (MSG) on secretion of the glucagon-

like peptide-1 (GLP-1) gut hormone and GLP-1

receptor interaction", Toxicology Letters, 2017.

Publication

36 Handbook of Experimental Pharmacology,

2011.

37 www.hindawi.com

38 Sevane, N., E. Armstrong, O. Cortés, P. Wiener, R. Pong Wong, and S. Dunner. "Association of bovine meat quality traits with genes included in the PPARG and PPARGC1A networks", Meat Science, 2013. 